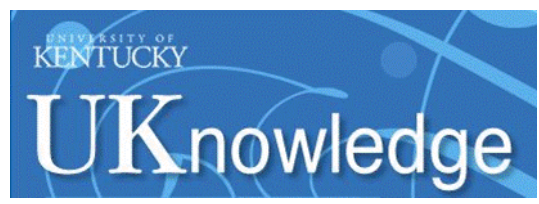

University of Kentucky

UKnowledge

\title{
Copyright, Originality, and the End of the Scenes a Faire and Merger Doctrines for Visual Works
}

\author{
Michael D. Murray \\ University of Kentucky Rosenberg College of Law, michael.murray1@uky.edu
}

Follow this and additional works at: https://uknowledge.uky.edu/law_facpub

Part of the Intellectual Property Law Commons

Right click to open a feedback form in a new tab to let us know how this document benefits you.

\section{Repository Citation}

Murray, Michael D., "Copyright, Originality, and the End of the Scenes a Faire and Merger Doctrines for Visual Works" (2006). Law Faculty Scholarly Articles. 665.

https://uknowledge.uky.edu/law_facpub/665

This Article is brought to you for free and open access by the Law Faculty Publications at UKnowledge. It has been accepted for inclusion in Law Faculty Scholarly Articles by an authorized administrator of UKnowledge. For more information, please contact UKnowledge@lsv.uky.edu. 
Copyright, Originality, and the End of the Scenes a Faire and Merger Doctrines for Visual Works

\section{Notes/Citation Information}

Michael D. Murray, Copyright, Originality, and the End of the Scenes a Faire and Merger Doctrines for Visual Works, 58(3) Baylor L. Rev. 779-860 (2006). 


\title{
COPYRIGHT, ORIGINALITY, AND THE END OF THE SCÈNES $A$ FAIRE AND MERGER DOCTRINES FOR VISUAL WORKS
}

\author{
Michael D. Murray*
}

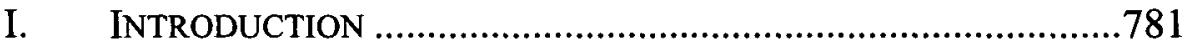

II. THE MERGER DOCTRINE AND SCÈNES Ȧ FAIRE DOCTRINE ......784

A. Originality in Copyright .............................................784

B. The Scope of Protection for Ideas Versus Expressions...786

C. Doctrines of Limitation Based on Originality: Merger and Scènes à Faire .........................................................788

III. EFFECTS OF THE EXPANDING APPLICATION OF THE MERGER AND SCENES À FAIRE DOCTRINES TO VISUAL WORKS .............798

A. Circuits With an Expansive View of the Application of the Merger and Scènes à Faire Doctrines to Visual Works.

1. First Circuit .............................................................799

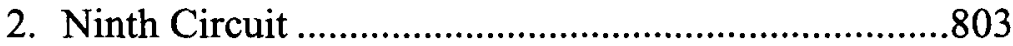

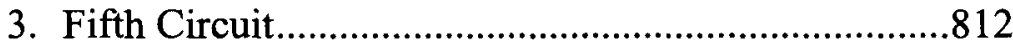

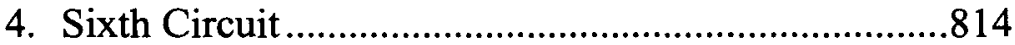

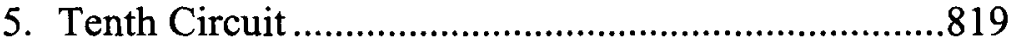

6. Eleventh Circuit ...................................................821

7. Federal Circuit ........................................................823

B. Circuits Restricting the Application of the Merger and Scènes à Faire Doctrines in the Visual Media Context ...824

"University of Illinois College of Law (Illinois). Professor Murray is a co-author of THE DESKBOOK OF ART LAW (Oxford University Press, Oceana Division 2004, 2005, 2006) and ART LAW: CASES AND MATERIALS (William S. Hein 2004). Many of Professor Murray's colleagues have supported him in the creation of this Article through their comments, input, advice, and general encouragement. Professor Murray thanks Professors Jane Ginsburg (Columbia Law School), Tom Ginsburg (Illinois), Craig Joyce (University of Houston Law Center), Richard Kaplan (Illinois), Jay Kesan (Illinois), Mark Lemley (Stanford Law School), Peter Maggs (Illinois), Tyler Ochoa (Santa Clara University School of Law), and Larry Solum (Illinois) for these things. He especially thanks Samantha Bell, Michelle Chen, Sara Arroyo, Anna DownsTemple, Steve Monde, Megan Segura, and Tobiah Utter for their able research, and Mary Parsons for her on-going support. 


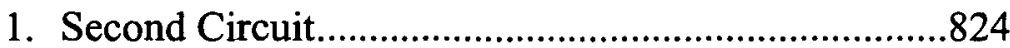

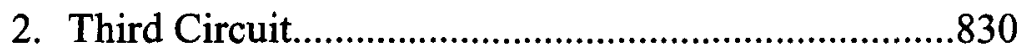

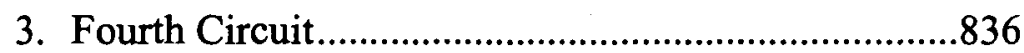

4. Seventh Circuit.............................................................838

5. Eighth Circuit..............................................................84

6. District of Columbia Circuit .........................................845

IV. REJECTION OF THE MERGER DOCTRINE AND SCÈNES Ȧ FAIRE DOCTRINE FOR VISUAL WORKS ...............................................848

A. Allegations of Literal or Actual Copying Defeat the Need for the Application of the Merger and Scènes à Faire Doctrines

B. Judges Reveal an Ignorance of Creative, Original Artistic Combinations and Additions to Works Through an Expansive Application of the Merger and Scènes à Faire Doctrines

C. An Expansive Application of the Merger and Scènes à Faire Doctrines Denies Visual Artists the Protection of the Copyright Laws by Taking the Substantial Similarity Determination Away From the Finder of Fact.

VI. CONCLUSION: RECOMMENDATIONS AND SOLUTION?

A. Solution: Eliminate the Application of the Merger and Scènes à Faire Doctrines to Visual Works 858

B. Recommendation: Impose a Burden on the Alleged Plagiarist to Produce the Image Copied by the Original Artist in Order to Trigger the Application of the Merger and Scènes à Faire Doctrines to Visual Works.

C. Recommendation: Allow the Finder of Fact to Evaluate the Total Look and Feel of the Two Competing Visual Works, but Impose a Check on the Process with Sspecial Verdict Forms. 


\section{INTRODUCTION}

Compare two works, one of which is alleged to be a copy of the other. The first is the Mona Lisa by Leonardo da Vinci. ${ }^{1}$ The second is another portrait of a woman with long, dark hair sitting in a window overlooking a somewhat dramatic landscape of twisting roads and bending rivers. A determination must be made as to whether the second work is an infringement of the Mona Lisa. ${ }^{2}$ There is no direct evidence of copying; therefore, the two works must be compared for substantial similarity. ${ }^{3}$

Consideration now must be given to the merger doctrine in the area of copyrights which states that if an idea and the expression of the idea are so tied together that the idea and its expression are one-there is only one conceivable way to express and embody the idea in a work-then the expression of the idea is not copyrightable because ideas may not be copyrighted. ${ }^{4}$ The scènes à faire doctrine complements the merger doctrine

${ }^{1}$ Portrait of Mona Lisa (1503-06), also known as La Gioconda, the wife of Francesco del Giocondo, oil on wood, $77 \times 53 \mathrm{~cm}$, Musee du Louvre, Paris, France, available at $\mathrm{http} / / / \mathrm{www}$.harley.com/art/abstract-art/images/(davinci)-mona-lisa.jpg (last visited Apr. 5, 2006).

${ }^{2}$ This will require a little imagination because the Mona Lisa is most definitely in the public domain, but this example depends on the Mona Lisa being protected by copyright.

${ }^{3}$ In the absence of direct proof of actual copying, which is to say in the majority of copyright infringement cases, a court must make a determination of whether or not the defendant copied using a two part test: (1) whether the defendant had access to the plaintiff's work, and (2) whether the works are similar enough to suggest that it is likely that the defendant copied the plaintiff's work. See MiTek Holdings, Inc. v. Arce Eng'g Co., 89 F.3d 1548, 1554 (11 th Cir. 1996); Rogers v. Koons, 960 F.2d 301, 307 (2d Cir. 1992). If there is sufficient proof of access and probative similarity to suggest copying, then the court compares the two works for substantial similarity to determine whether the defendant's copying of the plaintiff's work constitutes infringement. See MiTek, 89 F.3d at 1554; Rogers, 960 F.2d at 307-08. "Striking similarity" between the works is held to be conclusive proof of copying even in the absence of proof of access. Positive Black Talk Inc. v. Cash Money Records Inc., 394 F.3d 357, 371 \& n.10 (5th Cir. 2004); Repp v. Webber, 132 F.3d 882, 889 (2d Cir. 1997). But even overwhelming proof of access does not take the place of evidence of probative similarity to infer copying. See Positive Black Talk, 394 F.3d at 371 \& n. 10 .

${ }^{4}$ See, e.g., Educ. Testing Servs. v. Katzman, 793 F.2d 533, 539 (3d Cir. 1986). There is a great deal of scholarship discussing the merger doctrine. E.g., Mark A. Lemley, What's Different about Intellectual Property?, 83 TEX. L. REV. 1097, 1101 (2005) [hereinafter Lemley, What's Different]; Jane C. Ginsburg, "The Exclusive Right to Their Writings": Copyright and Control in the Digital Age, 54 ME. L. REv. 195, 210 \& n.91 (2002); Scott Abrahamson, Comment, Seen One, Seen Them All? Making Sense of the Copyright Merger Doctrine, 45 UCLA L. REV. 1125 (1998); Mark A. Lemley, Convergence in the Law of Software Copyright?, 10 HIGH TECH. L.J. 1, 9-10 (1995) [hereinafter Lemley, Convergence]; L. Ray Patterson \& Craig Joyce, Monopolizing 
by providing that certain subject matter-stock images, tried and true story lines, fables and folklore, scenes of nature, common visual and cultural references, all of which fall under the title of "scenes that must be done"are not able to be copyrighted because they are part of the public domain and no one can obtain a monopoly on such images by putting them into a fixed and tangible medium of expression. ${ }^{5}$ As a result, in many jurisdictions, if the first work embodies any images that are scènes à faire or subject to the merger doctrine, one is required to cancel them out before considering whether the second work infringes on the first. In other words, the second work must have elements that are substantially similar to the protected elements of the first work, not the first work as a whole.

In our example, certainly the fact that the subject of the portrait is a woman must be canceled out because da Vinci can claim no monopoly on this subject matter. The long dark hair is common to many women; we must disregard it. The coy, shy (or is it knowing, mysterious, or inviting) expression on the woman's face must also be disregarded; facial expressions are natural images, not subject to capture and monopolization by any artist. Her posture is a natural image. Posing a sitter in a window overlooking a landscape of twisting roads and bending rivers surely is a stock image in portraiture-perhaps one that incorporates a scene from a fable or fairy tale that da Vinci cannot claim for his own. The simple frock she wears is not of intricate design and ornamentation-features that da Vinci might have claimed were products of his creative fancy and thus substantially original and protected. As it is, her attire fails to reveal creative elements and largely must be ignored. Lastly, the colors chosen by da Vinci for the work must be ignored; colors are in the public domain. ${ }^{6}$ At the end of this reductionist dissection process, there is little or no protected element to compare to the second work. Therefore, even if the second work

the Law: The Scope of Copyright Protection for Law Reports and Statutory Compilations, 36 UCLA L. REV. 719 (1989).

${ }^{5}$ See, e.g., Atari, Inc. v. N. Am. Philips Consumer Elecs. Corp., 672 F.2d 607, 616 (7th Cir. 1982), superseded by rule in part, Fed. R. Civ. P. 52(a), as recognized in Scandia Down Corp. v. Euroquilt, Inc., 772 F.2d 1423, 1429 (7th Cir. 1985); Hoehling v. Universal City Studios, Inc., 618 F.2d 972, 979 (2d Cir. 1980); Leslie A. Kurtz, Copyright: The Scènes à Faire Doctrine, 41 FLA. L. REV. 79 (1989) [hereinafter Kurtz]; see also Tyler T. Ochoa, Origins and Meanings of the Public Domain, 28 U. DAYTON L. REV. 215, 219 \& n.24, 254 (2002) [hereinafter Ochoa, Public Domain] (considering that patent law requires novelty, indispensable expressions are part of the public domain); Lemley, What's Different, supra note 4, at 1102; Lemley, Convergence, supra note 4 , at 11 .

${ }^{6}$ Ochoa, Public Domain, supra note 5, at 219. 
is manifestly similar in appearance to the work, da Vinci has so few protected elements in his work that no reasonable finder of fact could determine that the second work is substantially similar to the Mona Lisa. The court must grant summary judgment in favor of the artist of the second work.

Consider one additional example that moves us forward several centuries: Grant Wood's American Gothic. ${ }^{7}$ A second work looks suspiciously similar to Wood's masterpiece of Americana. But in many jurisdictions the merger and scènes à faire doctrine require one to filter out any unprotectable elements. Surely, the posing of a man and his daughter together must be disregarded. Such is the very nature of scènes à faire-a scene that must be done-and an artist wishing to paint a father and daughter side-by-side is common. The viewer must disregard the stern, almost comically morose expressions on the subjects' faces. Facial expressions are natural images, and Wood has no monopoly on stern-faced subjects. The posing in front of their home recreates a stock American image and, thus, must be disregarded. The fact that they are farmers and are dressed in classic "Sunday Best" attire (for farmers) is an image from the public domain for which Wood cannot claim credit. ${ }^{8}$ Farmers hold pitchforks, so forget the pitchfork. This kind of cliché must certainly be subject to the scènes à faire doctrine if not the merger doctrine. The architecture of the house (the quasi-Gothic design to the window of the house) in the background may be unique enough in design to allow Wood to claim protection for it. Thus, the only elements to compare are some of the ornamentation on the subjects, the brooch worn by the woman, the exact style of eyewear worn by the man, and the unique architecture of the building in the background. Perhaps Wood included too few protected elements to enable him to proceed with a copyright infringement claim, and the court may grant summary judgment for the artist of the second work before even considering the second work.

Such is the state of the copyright law in many parts of the United States. ${ }^{9}$ Although the courts have from time to time acknowledged that the standards for originality and creativity required for copyright are

${ }^{7}$ American Gothic (1930), oil on beaverboard, $74.3 \times 62.4 \mathrm{~cm}$, Art Institute of Chicago, Chicago, IIl., available at http://www.artic.edu/artaccess/AA_Modern/pages/MOD_5_lg.shtml (last visited Apr. 5, 2006) or http://www.npr.org/templates/story/story.php?storyld=4748148 (last visited Apr. 5, 2006).

${ }^{8}$ Ochoa, Public Domain, supra note 5, at 219.

${ }^{9}$ See Mitek Holdings, Inc. v. Arce Eng'g Co., 89 F.3d 1548, 1554 (11 th Cir. 1996). 
intentionally low-and that there are myriad ways to express themes and ideas visually - half of the circuits of the United States courts of appeals have applied the kind of "reductionist," dissection approach described in the two examples above in their consideration of infringement of visual works that is driven by an expanded view of the applicability of the merger and scènes à faire doctrines to visual works. ${ }^{10}$

This Article will first argue that the merger doctrine and scènes à faire doctrine are perfectly well adapted to verbal and literary works, but have no meaning and no proper application with regard to visual works and should be discarded in the consideration of infringement of visual works. Part II will describe the merger doctrine and scènes à faire doctrine that fall under the requirement of originality in the United States copyright law and explain the proper application of the doctrines to verbal and literary works. Part III will describe the current state of the law in which half of the circuits of the United States courts of appeals feel compelled by the existence of the merger and scènes à faire doctrines to engage in filtering and dissection and other reductionist approaches to the elements of visual works when evaluating substantial similarity in infringement cases. Finally, Part IV will complete the argument for a rejection of the merger and scènes à faire doctrines for visual works.

\section{THE MERGER DOCTRINE AND SCÈNES À FAIRE DOCTRINE}

\section{A. Originality in Copyright}

The discussion of originality in copyright law begins with one axiomatic proposition: There can be no valid copyright in facts. ${ }^{11}$ No author may copyright his ideas ${ }^{12}$ or the facts he narrates. ${ }^{13}$ The key to understanding the

\footnotetext{
${ }^{10} I d$; Rogers v. Koons, 960 F.2d 301, 308 (2d Cir. 1992).

"Feist Publ'ns, Inc. v. Rural Tel. Serv. Co., 499 U.S. 340, 344 (1991). The Feist case and the originality requirements defined therein are discussed in Tyler T. Ochoa, 1984 and Beyond: Two Decades of Copyright Law, 20 SANTA ClARA COMPUTER \& HiGH TECH. L.J. 167, 169-70 (2003); Daniel J. Gervais, Feist Goes Global: A Comparative Analysis of the Notion of Originality in Copyright Law, 49 J. COPYRIGHT SOC'Y U.S.A. 949 (2002); Jane C. Ginsburg, Wendy J. Gordon, Arthur R. Miller, \& William F. Patry, The Constitutionality of Copyright Term Extension: How Long Is Too Long?, 18 CARDOZo ARTS \& ENT. L.J. 651, 660-63 (2000); Jane C. Ginsburg, No "Sweat"? Copyright and Other Protection of Works of Information after Feist v. Rural Telephone, 92 COLUM. L. REV. 338, 367-87 (1992).

${ }^{12}$ See 17 U.S.C. $\$ 102(b)(2000)$.
} 
merger and scènes $\grave{a}$ faire doctrines lies in understanding why facts are not copyrightable.

In Feist, the Supreme Court explained the meaning of a copyright:

The sine qua non of copyright is originality. To qualify for copyright protection, a work must be original to the author. Original, as the term is used in copyright, means only that the work was independently created by the author (as opposed to copied from other works), and that it possesses at least some minimal degree of creativity. ... To be sure, the requisite level of creativity is extremely low; even a slight amount will suffice. The vast majority of works make the grade quite easily, as they possess some creative spark, "no matter how crude, humble or obvious" it might be. ${ }^{14}$

Originality is not the same thing as novelty. ${ }^{15}$ A work may be original even if it closely resembles another work or several different works. ${ }^{16}$ The single requirement of originality is that any similarity between the new work and older works must be accidental and fortuitous; the product of random, independent creation. ${ }^{17}$ The similarity must not be the result of copying. ${ }^{18}$ Thus, the copyright requirement of originality amounts to little more than a prohibition on actual copying. ${ }^{19}$

Alternatively, no one may claim originality as to the reporting and publication of facts. ${ }^{20}$ Facts, data, and information about the world do not

${ }^{13}$ Feist, 499 U.S. at $344-45$; Harper \& Row, Publishers, Inc. v. Nation Enters., 471 U.S. 539, 556 (1985).

${ }^{14}$ Feist, 499 U.S. at 345 (citing 1 MELVILle B. NIMMER \& DAVID NIMMER, NIMMER ON COPYRIGHT $\S 1.08[C][1](1990)$ ); see Harper \& Row, 471 U.S. at 547-49; 1 PAUL GolDSTEIN, COPYRIGHT $\S 2.2 .1$ (2d ed. 2005) [hereinafter Goldstein]; 1 MELVILLE B. NIMMER \& DAVID NIMMER, NIMMER ON COPYRIGHT $§ \$ 2.01$ [A], [B] (2005) [hereinafter Nimmer].

${ }^{15}$ Feist, 499 U.S. at 345; Goldstein, supra note 14, $\$ 2.2 .1$.

${ }^{16}$ See Feist, 499 U.S. at 345; Goldstein, supra note 14, § 2.2.1.

${ }^{17}$ See Feist, 499 U.S. at 345.

${ }^{18}$ See id.

${ }^{19}$ See Feist, 499 U.S. at 345-46; The Trade-Mark Cases, 100 U.S. 82, 94 (1879) (holding originality requires independent creation plus a modicum of creativity); Sheldon v. MetroGoldwyn Pictures Corp., 81 F.2d 49, 54 (2d Cir. 1936) (Hand, J.).

${ }^{20}$ Feist, 499 U.S. at 347 ; Goldstein, supra note 14, $\S 2.2 .1$; Nimmer, supra note $14, \S$ $2.11[\mathrm{~A}]$. 
owe their origin to an act of authorship. ${ }^{21}$ The first person to find and report a particular fact has not created the fact; he or she has merely discovered its existence. $^{22}$ Facts are not original to an author who writes about those facts. "[A]11 facts-scientific, historical, biographical, and news of the day"belong to the public domain and are available to every person. ${ }^{23}$

Nevertheless, while others may copy the underlying facts and ideas from a publication, they may not copy the exact words or arrangement used to present them. ${ }^{24}$ For example, the facts of a president's life are subject to copying and republication but not his exact words and phrases regarding public figures and public events written in an autobiography. ${ }^{25}$ The artist or author's creative expression and embodiment of the idea is protected. ${ }^{26}$ Copyright assures authors the right to control their original expression, but encourages others to borrow the underlying ideas and themes used by the original author and create their own original expression. ${ }^{27}$ This principle, known as the idea-expression dichotomy, applies to all works of authorship. ${ }^{28}$

\section{B. The Scope of Protection for Ideas Versus Expressions}

The definition of an "idea" in a literary work often is the most difficult aspect of the idea-expression dichotomy. ${ }^{29}$ Judge Learned Hand characterized the difficulty in Nichols v. Universal Pictures Corp. as arising from the fact that an idea, as opposed to the expression of the idea in literature, can be manipulated by viewing the interest protected by copyright at differing levels of abstraction. ${ }^{30}$ If protection is limited to the words as they appear on the page-a strictly literal application of the term "expression"- the protection for original "Writings" envisioned by the

${ }^{21}$ Feist, 499 U.S. at 347; Goldstein, supra note 14, $\$ 2.2 .1$.

${ }^{22}$ Feist, 499 U.S. at 347.

${ }^{23}$ Feist, 499 U.S. at 347; Miller v. Universal City Studios, Inc., 650 F.2d 1365, 1369 (5th Cir. 1981); Goldstein, supra note 14, § 2.2.1.

${ }^{24}$ See Feist, 499 U.S. at 348.

${ }^{25}$ Harper \& Row Publishers, Inc. v. Nation Enters., 471 U.S. 539, 556-57, 563 (1985).

${ }^{26}$ Id.; Feist, 499 U.S. at 348-49.

${ }^{27}$ Feist, 499 U.S. at 349-50; Harper \& Row, 471 U.S. at 556-57.

${ }^{28}$ Feist, 499 U.S. at 350; see Harper \& Row, 471 U.S. at 556-57. See generally Goldstein, supra note $14, \S 2.3$.

${ }^{29}$ See Goldstein, supra note 14 , § 2.3.1.1; Nimmer, supra note $14, \S 1.10[\mathrm{~B}][2]$.

${ }^{30} 45$ F.2d 119, 121 (2d Cir. 1930); see also Nash v. CBS, Inc., 899 F.2d 1537, 1540 (7th Cir. 1990) (discussing Nichols). 
Constitution ${ }^{31}$ would be considerably thin. ${ }^{32}$ A new author could imitate the plot, character types, exposition, conflict, resolution, and all other original elements of a novel so long as she changed the wording. ${ }^{33}$ Bui if protection extends to the full range of derivative works that might be expressed by the author arising from the author's fleshing out of an "idea" in literature, then an author could claim property rights to an entire genre. ${ }^{34}$ This would mean that Edgar Allan Poe or Wilkie Collins could have captured the mystery genre with the publication of a single mystery story; the innovators of the first reality television show, Survivor, might have deprived the public of The Amazing Race, Fear Factor, Big Brother, or even Temptation Island. ${ }^{35}$

This difficulty is not present in visual works because there are myriad possible ways to express ideas visually; ${ }^{36}$ a new author need only refrain from copying one. A perfect example of the idea-expression dichotomy in visual works is the case of photography. Photography takes as its subject the concrete objects (the facts) of the world around us, and yet for over a hundred and twenty years the Supreme Court has recognized that works of photography are sufficiently creative and original as to obtain the protection of copyright. ${ }^{37}$ This is true for staged and posed subjects of photographs, as well as for advertising and for more natural or random snap-shots. ${ }^{38}$ What

${ }^{31}$ U.S. CONST. art. I, $\S 8$, cl. 8 .

${ }^{32}$ Nimmer, supra note $14, \S 1.10[\mathrm{~B}][2]$; see Goldstein, supra note $14, \S 2.3 .1 .2$ (stating that when idea and expression are inseparable, protecting the expression would confer a monopoly of the idea).

${ }^{33}$ See Nichols, 45 F.2d at 121.

${ }^{34}$ Nimmer, supra note $14, \S \S 1.10[\mathrm{~B}][2],[\mathrm{C}][2]$; see also Goldstein, supra note $14, \S 2.3 .2$.

${ }^{35}$ Southco, Inc. v. Kanebridge Corp., 390 F.3d 276, 291 (3d Cir. 2004) (en banc) (Roth, J., dissenting), cert. denied, 126 S. Ct. 336 (2005); Nash, 899 F.2d at 1540.

${ }^{36}$ Mattel, Inc. v. Goldberger Doll Mfg. Co., 365 F.3d 133, 135 (2d Cir. 2004) (holding that there are innumerable ways of depicting doll faces); Southco, 390 F.3d at 292 (Roth, J. dissenting) (stating that Southco's numbering rules and the resulting numbers are one of many possible expressions of the idea of using a code to convey product specifications); Atari Games Corp. v. Oman, 979 F.2d 242, 245 (D.C. Cir. 1992) [hereinafter Atari II] (Ginsburg, J.) (holding that there are innumerable ways of depicting breakout game features), appeal after remand from 888 F.2d 878 (D.C. Cir. 1989) [hereinafter Atari I] (Ginsburg, J.).

${ }^{37}$ See Burrow-Giles Lithographic Co. v. Sarony, 111 U.S. 53, 60-61 (1884); Leigh v. Warner Bros., Inc., 212 F.3d 1210, 1215-16 (11th Cir. 2000). Yet, there are dissenting voices regarding the recognition of photography as a creative, original, copyrightable media. See generally Christine Haight Farley, The Lingering Effects of Copyright's Response to the Invention of Photography, 65 U. PITT. L. REV. 385, 446-51 (2004) (criticizing the conception of the authorship used for photographs).

${ }^{38}$ See Bleistein v. Donaldson Lithographing Co., 188 U.S. 239, 251 (1903); Burrows-Giles 
the author of a photographic work brings to the creativity and originality equation is an artist's sense of composition, angle, exposure, F-stop and aperture settings, background, lighting, and the creation of certain elements of the scene. ${ }^{39}$ In Mannion v. Coors Brewing Co., the Southern District of New York categorized photographic originality into three specific areas: rendition of the photograph (angle, light, shade, exposure, filter effects, developing techniques, or composition), the timing of the photograph (how it fortuitously or consciously captures the moment when the expression associated with the subject matter is the most poignant), and the creation of the subject matter of the photograph (i.e. when the photographer stages or creates original subject matter for photographing). ${ }^{40}$ However, nothing in these original elements prevents another author from photographing, painting, writing about, or otherwise using the same subject matter (the facts) in their own original expression as long as they do not copy the first author's expression. ${ }^{41}$

\section{Doctrines of Limitation Based on Originality: Merger and Scènes à Faire}

Copyright protection is subject to an important limitation: "The mere fact that a work is copyrighted does not mean that every element of the work may be protected." ${ }^{42}$ The requirement of originality means that copyright protection extends only to those components of a work that are original to the author. ${ }^{43}$

The merger doctrine is a variation or application of the idea-expression dichotomy. When the idea and the expression of the idea are inseparable, then the expression will not be copyrightable because it would necessarily give the author a monopoly on the expression of the underlying idea. ${ }^{44}$ In other words, if there is only one way to express or depict an idea then no

Lithographic Co., 111 U.S. at 60; Kelly v. Arriba Soft Corp., 336 F.3d 811, 820 (9th Cir. 2003); Leigh, 212 F.3d at 1215; Los Angeles News Serv. v. Tullo, 973 F.2d 791, 794 (9th Cir. 1992).

${ }^{39}$ Bleistein, 188 U.S. at 250 ; Ets-Hokin v. Skyy Spirits, Inc., 225 F.3d 1068, 1077 (9th Cir. 2000); Los Angeles News Serv., 973 F.2d at 794 (quoting United States v. Hamilton, 583 F.2d 448, 452 (9th Cir. 1978)).

${ }^{40} 377$ F. Supp. 2d 444, 452-53 (S.D.N.Y. 2005).

${ }^{41}$ See id. at 454; Ets-Hokin, 225 F.3d at 1082; Mason v. Montgomery Data, Inc., 967 F.2d 135, 138 (5th Cir. 1992).

${ }^{42}$ Feist Publ'ns, Inc. v. Rural Tel. Serv. Co., 499 U.S. 340, 348 (1991).

${ }^{43}$ Id.

${ }^{44}$ Educ. Testing Servs. v. Katzman 793 F.2d 533, 539 (3d Cir. 1986). 
one may claim a copyright in that single manner of expression or depiction because that would evict everyone else from the right to express or depict that idea. ${ }^{45}$

The merger doctrine is traced to Learned Hand's opinion in Nichols $v$. Universal Pictures Corp., which links the principles underlying the merger doctrine to those underlying the scènes à faire doctrine, although neither doctrine is named in the opinion. ${ }^{46}$ The Nichols case involved two literary works (a stage play and a screenplay) alleged to be substantially similar. ${ }^{47}$ There was no allegation that actual scenes or actual text was copied from the first work into the second, but Judge Hand observed that: "It is of course essential to any protection of literary property, whether at commonlaw or under the statute, that the right cannot be limited literally to the text, else a plagiarist would escape by immaterial variations." ${ }^{, 48}$ The first work involved a Jewish widower whose son secretly married an Irish Catholic girl whose widower father opposed the union as did the Jewish father. ${ }^{49}$ Eventually, the two fathers reconcile in order to rejoin the company of their respective children and grandchildren. ${ }^{50}$ The second work involved a Jewish family who lived in a state of animosity with their neighbors, an Irish Catholic family. ${ }^{51}$ The plot centered around the quarrelling of the two families: the fathers fought, the mothers bickered, and even the children and pets clashed. ${ }^{52}$ The only family members not engaged in the squabble were the Jewish daughter and the Irish son, who, as you may have guessed, secretly married. ${ }^{53}$ Further conflict is introduced when the Jewish father inherits a sizeable sum of money, but later learns that the proper legatee is the Irish father, and by turning over the money, he prompts an unlikely friendship and partnership between the two fathers. ${ }^{54}$

Judge Hand noted the difficulty in applying the merger doctrine:

\footnotetext{
${ }^{45}$ See Goldstein, supra note $14, \S 2.3 .2$.

${ }^{46} 45$ F.2d 119, 120-21 (2d Cir. 1930).

${ }^{47} I d$. at 120 .

${ }^{48} I d$. at 121 .

${ }^{49} \mathrm{Id}$. at 120 .

${ }^{50} I d$. at $120-22$.

${ }^{51} I d$. at 120.

${ }^{52} \mathrm{Id}$.

${ }^{53} \mathrm{Id}$.

${ }^{54} I d$. at 121.
} 
[W]hen the plagiarist does not take out a block in situ [sic], but an abstract of the whole, decision is more troublesome. Upon any work, and especially upon a play, a great number of patterns of increasing generality will fit equally well, as more and more of the incident is left out. The last may perhaps be no more than the most general statement of what the play is about, and at times might consist only of its title; but there is a point in this series of abstractions where they are no longer protected, since otherwise the playwright could prevent the use of his "ideas," to which, apart from their expression, his property is never extended. Nobody has ever been able to fix that boundary, and nobody ever can. ${ }^{55}$

The opinion declared that stealing lines or scenes or stealing specific characters from a work may be actionable if it is a substantial taking. ${ }^{56}$ The court reasoned that the comparison of the similarity between two plots and storylines requires examination at the lowest level of abstraction that it takes to find the two works are the same; if the works are only similar at a high level of abstraction, it will be less likely that their similarity will constitute actionable infringement. ${ }^{57}$ For example, the two works at issue in Nichols may be abstracted as follows (starting with a high level of abstraction and working downward):

two works about two men with children;

two works about two men whose children marry;

two works about two men whose children marry causing the men grief and anger;

two works about two men whose children marry in secret causing the men grief and anger;

two works about two men from different religions whose children marry in secret causing the men grief and anger because of their religious differences;

two works about two men from different religions whose children marry in secret, causing the men grief and anger because of their religious differences, but who reconcile in the end;

\footnotetext{
${ }^{55} I d$. (citation omitted).

${ }^{56} I d$.

${ }^{57}$ Id.
} 
two works about a Jewish man and an Irish Catholic man whose children marry in secret, causing them grief and anger because of their religious differences, but who reconcile in the end;

and so on.

If the level of abstraction at which the works share the most similarities mainly involves the level of ideas (e.g., the idea of pig-headed men who cannot get along because of religious differences; the idea of men who overcome petty religious differences in favor of stronger values), or generalities (e.g., problems of marriages of two people from different religions; the situation of marriages that cause animosity in families but later produce a kind of coexistence), or repeats plot devices and stock themes common to many works (e.g., star-crossed lovers; feuding families brought together by a marriage of defectors; fathers who compromise because of love of children or grandchildren), then the works are similar at a level where the first author cannot claim protection. The abstraction of two literary works for comparison of the plot and storyline must not result in a pattern of similarity that eliminated so many disparate details of the works that the remaining similarities are simply plot ideas, stock themes, or common character types interacting in predictable ways. ${ }^{58}$ This is the level of abstraction where Judge Hand found the two works in Nichols, and he rejected the claim for infringement. ${ }^{59}$

The process of abstraction and comparison described in Nichols works well in literary pieces where individual authors, all using a common language (English), may discuss a common theme, plot device, or character-type or may flesh out a familiar scene or stock image. In such instances, all literary works will share commonalities if they share a common idea but not elements that are original to one author. The idea and the expression of the idea will merge in a literary sense as the idea itself captures the several words and phrases necessary to communicate the idea in writing. Judge Hand recognized that it is prudent to declare such plot ideas, character-types, familiar scenes, and stock images as part of the public domain, available to all authors who wish to embody the idea or scene in their own work. ${ }^{60}$ Thus, his decision is the grandfather of both the merger doctrine and the scènes à faire doctrine.

\footnotetext{
${ }^{58}$ Id. at $120-21$.

${ }^{59}$ Id. at $121-22$.

${ }^{60}$ See id.
} 
In the last two decades, the merger doctrine has seen the greatest increase in its application in cases concerning the copyrightability of computer programs. Computer programs are both literary (the source code and object code) ${ }^{61}$ and functional. ${ }^{62}$ Sometimes computer programs also produce visual results. The argument was raised and accepted in many computer code copyright cases that within a given programming language, certain results (the ideas) cannot be achieved without using certain expressions (source code). ${ }^{63}$ Thus, a merger of idea and expression was found and sequences of source code were declared to be uncopyrightable to avoid giving an early programmer a monopoly over a number of results in the context of the use of a certain programming language. ${ }^{64}$

The merger doctrine is inapplicable when the same idea can be expressed in a plurality of different manners. ${ }^{65}$ In these situations each author's creative original expression of the idea deserves copyright protection. $^{66}$

A perfect example of how courts misinterpret the merger doctrine in connection with visual works is the Ninth Circuit case of Herbert Rosenthal Jewelry Corp. v. Kalpakian. ${ }^{67}$ In Kalpakian, the court determined that there was only one way for the idea of a jeweled pin in the shape of a bee to effectively be depicted. ${ }^{68}$ As a result, the court ruled that the defendant could copy a plaintiff's depiction of a jeweled bee pin because the plaintiff's depiction was the only possible effective depiction, and the plaintiff cannot claim a copyright monopoly of the only available method of depicting an idea. ${ }^{69}$ The idea and the depiction are one, and no one can copyright an idea. $^{70}$ Although this is a venerated opinion, cited and

${ }^{61}$ Nimmer, supra note $14, \S 2.04[\mathrm{C}]$; see 17 U.S.C. $\S 101$ (2000) (definition of "computer program").

${ }^{62}$ Nimmer, supra note $14, \S 2.18[\mathrm{~J}]$.

${ }^{63}$ Id. $\S \S 2.04[\mathrm{C}], 2.18[\mathrm{~B}], 2.18[\mathrm{~J}]$; see Lemley, Convergence, supra note 4, at 11, 14, 16, 31.

${ }^{64}$ An outcome that should be precluded by Baker v. Selden, 101 U.S. 99, 103-04 (1879). See generally Nimmer, supra note $14, \S \S 2.04[\mathrm{C}], 2.18[\mathrm{~B}]$.

${ }^{65}$ Apple Computer, Inc. v. Franklin Computer Corp., 714 F.2d 1240, 1253 (3d Cir. 1983); Goldstein, supra note $14, \S 2.3 .2$.

${ }^{66}$ Goldstein, supra note 14, § 2.3.2; Dymow v. Bolton, 11 F.2d 690, 691 (2d Cir. 1926) (holding that when a myriad of variations of a scene are possible, a myriad of protectable copyrights can exist).

\footnotetext{
${ }^{67} 446$ F.2d 738 (9th Cir. 1971).

${ }^{68}$ See id. at 742 .

${ }^{69} \mathrm{See}$ id. at 740.

${ }^{70}$ See generally id.
} 
accepted for decades, ${ }^{71}$ the opinion is simply wrong. The fallacy of the opinion is that there is only one effective way to depict a jeweled bee pin. Nothing limits the creative potential of the designer of a jeweled bee pin other than the simple notion that the end product should resemble a bee. ${ }^{72}$ The amount of gold or other metal used and exposed in the design, the size and shape and number of the gems or semi-precious stones used, the color, tone, shade, clarity, and brilliance of the gems or stones used, whether the gems or stones will have few or many or no facets are simply the beginning of the creative opportunities available to a designer of a jeweled bee pin. ${ }^{73}$ The plaintiff monopolizes nothing by coming out with one possible design when there are so many other available designs. In the light of these creative opportunities, there is no need to allow the defendant to copy plaintiff's single and original design.

The scènes à faire doctrine compliments the merger doctrine when it is applied to literary works. The scènes $\dot{a}$ faire doctrine provides that when discussing a certain topic, story-line, or genre, there are certain themes, scenes, incidents, character types, or settings that, as a practical matter, must be used to properly treat the topic. ${ }^{74}$ A literary discussion of a salmon run will inevitably describe how they swim for hundreds of miles, fly up over waterfalls, some being snatched in mid-air by hungry grizzly bears, and the rest striving to return to the pools where they were spawned. Motion pictures following the boy-meets-girl, boy-gets-girl, boy-loses-girl, boy-gets-girl-back storyline inevitably will employ character types of thoughtless boys and petulant girls, and contain similar scenes of miscommunication, anger, and reconciliation in their conflict development and conflict resolution. A discussion of the Three Stooges' or Chris

${ }^{71}$ E.g., Goldstein, supra note $14, \S 2.3 .2$.

${ }^{72}$ If the only similarity between the two works was that they both resembled a bee, then the plaintiff's claim of infringement properly failed. The similarity would have been limited to the shared concept or idea of the two works, and the idea itself is not copyrightable. If the holding of Kalpakian were limited to this proposition, the case would be correct. But the opinion goes much farther by declaring that plaintiff produced the only possible design and depiction of a jeweled bee inviting every subsequent jeweler to copy plaintiff's bee design without limitation. See Herbert Rosenthal Jewelry, 446 F.2d at 742.

${ }^{73}$ The record unfortunately indicates that plaintiff's counsel was not sufficiently knowledgeable about jewelry when it came to explaining the different design opportunities available to the defendant. See id. at 740.

${ }^{74}$ E.g., Atari Inc., v. N. Am. Philips Consumer Elecs. Corp., 672 F.2d 607, 616 (7th Cir. 1982), superseded by rule in part, Fed. R. Civ. P. 52(a), as recognized in Scandia Down Corp. v. Euroquilt, Inc 772 F. 2d 1423 (7th Cir. 1985); see Goldstein, supra note 14, § 2.3.2. 
Farley's movies will inevitably contain references to "slap-stick," "prat falls," "physical comedy," and "self-effacing humor." The works discussing these scenes and themes will use similar language even at a fairly low level of abstraction because the very idea that is being expressed requires authors to use certain terminology and phrasing. ${ }^{75}$ An author's use of these terms and phrases is not original and cannot impose a monopoly on the terms and phrases associated with the scene or theme. ${ }^{76}$

When applied in the context of literary or utilitarian works, the scènes $\dot{a}$ faire doctrine means that copyright protection is denied to common elements of work that are essential to the presentation of the subject matter of the work. ${ }^{77}$ The rationale for the rule is that elements dictated by subject matter itself necessarily lack originality. ${ }^{78}$ Another way of looking at it is that stock images and themes that are covered under the scènes à faire doctrine are in the public domain, and are thus free to be used by all. ${ }^{79}$ In a true scènes à faire situation, the plaintiff author is as likely to have drawn her material from the public domain as the plagiarist is, and it is even more likely that the alleged plagiarist has not copied plaintiff author's work at all, but instead drew the material from the public domain.

The scènes à faire doctrine has no proper application in the case of visual works. ${ }^{80}$ To the extent that the idea of certain images is in the public domain, they are free for use whether characterized as scènes à faire or simply themes and ideas. ${ }^{81}$ In the visual work context, all themes and ideas (mundane ideas and clever ideas, stock images and innovative images, scenes that must be done and those that are more optional) are proper subjects for works as long as the author does not copy the expression of

${ }^{75}$ See Goldstein, supra note $14, \S 2.3 .2$.

${ }^{76} I d$.

${ }^{77}$ Dun \& Bradstreet Software Servs., Inc. v. Grace Consulting, Inc., 307 F.3d 197, 214-15 (3d Cir. 2002); Mitel, Inc. v. Iqtel, Inc., 124 F.3d 1366, 1375 (10th Cir. 1997). See generally Kurtz, supra note 5, at 90-96; Goldstein, supra note 14, § 2.3.2.

${ }^{78}$ Dun \& Bradstreet, 307 F.3d at 214-15; Mitel, 124 F.3d at 1375.

${ }^{79}$ See Incredible Techs., Inc. v. Virtual Techs., Inc., 400 F.3d 1007, 1011-12 (7th Cir. 2005); Swirsky v. Carey, 376 F.3d 841, 850 (9th Cir. 2004); Murray Hill Publ'ns, Inc. v. Twentieth Century Fox Film Corp., 361 F.3d 312, 319 (6th Cir. 2004); Tufenkian Imp./Exp. Ventures, Inc. v. Einstein Moomjy, Inc., 338 F.3d 127, 132 (2d Cir. 2003); Computer Mgmt. Assistance Co. v. Robert F. DeCastro, Inc., 220 F.3d 396, 401 (5th Cir. 2000).

${ }^{80}$ See Southco, Inc. v. Kanebridge Corp., 390 F.3d 276, 287 (3d Cir. 2004) (en banc) (Becker, J., concurring), cert. denied, 126 S. Ct. 336 (2005).

${ }^{81}$ See Murray Hill Publ'ns, 361 F.3d at 319. 
another copyrighted visual work. ${ }^{82}$ In other words, there is no single visual expression of stock theme or commonplace idea that must be copied in order for the "scene" to be "done" properly. That is why many courts have recognized that scènes à faire is a doctrine that applies to literary or dramatic works. ${ }^{83}$ It does not fit with visual works.

The idea of a soup can as the subject of a painting is in the public domain, but Andy Warhol's embodiment of that idea in the form of a Warhol painting of a Campbell's soup can is not in the public domain. ${ }^{84}$ No artist wishing to embody the idea of a soup can in their work needs to copy Warhol's embodiment of that idea. They are free to paint all the soup cans they want (in a copyright sense, without regard to the limitations of other areas of the law, such as trademark, unfair competition, and false designation of origin laws) as long as they do not copy Warhol's embodiment of the idea. Jeff Koons can paint or sculpt a work embodying the idea of two people holding a string of puppies in their laps; he just cannot copy Art Roger's embodiment of that idea in the form of an Art Roger photograph. ${ }^{85}$

The difficulties in applying the idea-expression dichotomy in photography in light of the lurking presence of the merger and scènes $\dot{a}$ faire doctrines is revealed by comparing two cases from the federal trial court of the Southern District of New York, Mannion v. Coors Brewing Co. $^{86}$ and Kaplan v. Stock Market Photo Agency, Inc. ${ }^{87}$ In Mannion, the court considered a photograph of basketball star Kevin Garnett who was depicted wearing a considerable assortment of men's jewelry. ${ }^{88}$ A similar photograph appeared as part of a Coors billboard advertisement, where the allegedly plagiarized photograph zeroed in on the hands and mid-section of the model. ${ }^{89}$ Similarities were noted in the heavily veined hands of the

${ }^{82}$ See Country Kids 'N City Slicks, Inc. v. Sheen, 77 F.3d 1280, 1286-87 (10th Cir. 1996).

${ }^{83}$ Southco, 390 F.3d at 287 (Becker, J., concurring); Lexmark Int'l., Inc. v. Static Control Components, Inc., 387 F.3d 522, 535 (6th Cir. 2004); Murray Hill Publ'ns, 361 F.3d at 319-20; Cavalier v. Random House, Inc., 297 F.3d 815, 823 (9th Cir. 2002); Sheen, 77 F.3d at 1286.

${ }^{84}$ Assuming no lapse in the registration, renewal, and protection for works created prior to 1979 , the copyright should last at least until 70 years after Warhol's death. 17 U.S.C. $§$ 302(a) (2000).

\footnotetext{
${ }^{85}$ See Rogers v. Koons, 960 F.2d 301, 307-08 (2d Cir. 1992).

${ }^{86} 377$ F. Supp. 2d 444 (S.D.N.Y. 2005).

${ }^{87} 133$ F. Supp. 2d 317 (S.D.N.Y. 2001).

${ }^{88} 377$ F. Supp. $2 \mathrm{~d}$ at 447 (referring to it as "bling bling").

${ }^{89} I d$. at 448 .
} 
model in both photographs, the same white athletic attire, and the same number, type, assortment, and placement of the items of jewelry worn by the model, although the composition of the allegedly infringing work was a mirror image of the original..$^{90}$ Coors and its ad agency defended the allegations by asserting that plaintiff's photograph was not protectable: It was a rendition of an unprotectable idea-a heavily bejeweled AfricanAmerican man - and any alleged similarities between the two works were attributable to the fact that both photographers had chosen to depict the same subject matter. ${ }^{91}$ Subject matter from the real world is fact, and the idea of depicting such subject matter in a photograph is an idea, and ideas and facts are not copyrightable.

The Mannion court rejected these assertions in their entirety. ${ }^{92}$ The court noted that photographs are readily copyrightable, and the creative, original elements are found in the photographer's rendition of the photograph, the timing of the photograph, or the creation of the subject matter of the photograph. ${ }^{93}$ The court noted the originality of plaintiff's creation and the rendition of the subject matter and the substantial similarity between defendants' depiction and plaintiff's ${ }^{94}$ and denied defendants' summary judgment motion. ${ }^{95}$

In Kaplan, the court declared that the second of two photographs, each depicting a person in businessman's attire staring down at his feet which dangle over the edge of a tall building as if he is contemplating a leap from the edge (i.e., a photograph of a potential executive jumper taken from the jumper's perspective) could not be held to infringe the first photograph. ${ }^{96}$ The court reasoned that the general similarity between the two works was attributed to the two photographers' choices to depict the same subject matter, and any direct similarities between the actual photographs was

${ }^{90}$ See id. and Images 1 and 2 attached to the opinion.

${ }^{91}$ Id. at $452,455-56,462$.

${ }^{92}$ Id. at $462-63$.

${ }^{93}$ Id. at $452-53$.

${ }^{94}$ Id. at 456 ("The 'idea' (if one wants to call it that) [of the photograph] postulated by the defendants does not even come close to accounting for all the similarities between the two works, which extend at least to angle, pose, background, composition, and lighting. It is possible to imagine any number of depictions of a black man wearing a white T-shirt and 'bling bling' that look nothing like either of the photographs at issue here.").

${ }^{95}$ Id. at 462-63.

${ }^{96}$ See Kaplan v. Stock Mkt. Photo Agency, Inc., 133 F. Supp. 2d 317, 323-26 (S.D.N.Y. 2001). 
necessitated by the common scene and subject matter of the photographs. ${ }^{97}$ If that were the extent of the discussion, the case would gel nicely with Mannion, but the court goes on to state that "[i]t would be impossible to depict the photograph's subject matter without portraying [the subject] in [the] pose" selected by the original photographer. ${ }^{98}$ Then, the court incongruously identifies several aspects of the two photographers' rendition or staging of the photograph that were freely open to artistic creativity: the point of view of the photograph (bird's eye, over the shoulder, frontal, below from a far angle, below from a direct upward angle, or from the jumper's point of view), the cropping of the photograph (close up, medium, wide angle), the angle of the jumper's perspective (e.g., whether it took in a snippet of pin-striped pants legs or a knee to shoe length of pin-striped pants legs), the shading of the street below in the one photograph and the inclusion of a second building closely abutting the opposite side of the street in the other photograph. ${ }^{99}$ With respect to the point of view, the court even admits: "There may be, as [plaintiff] Kaplan suggests, many other angles from which to depict the scene..." ${ }^{100}$ Nevertheless, the court believed that each artistic decision of the original photographer was dictated by the merger of the subject matter with the depiction and any specific elements of the depiction not merged with the idea of the subject matter were scènes à faire of the scene depicted. ${ }^{101}$

The Mannion court rejected the application of the merger and scènes $\dot{a}$ faire doctrines to visual works because it held that the idea-expression distinction should be severely limited in cases involving visual works, while in Kaplan the court placed no such limitation on their application to visual works. ${ }^{102}$ Mannion discussed the abstraction analysis of Nichols and the concept of the "line" that must be drawn where the second work takes too much protected original expression because it encompasses too specific an abstraction of the first work. ${ }^{103}$ Mannion stated that with respect to visual media, such as photography:

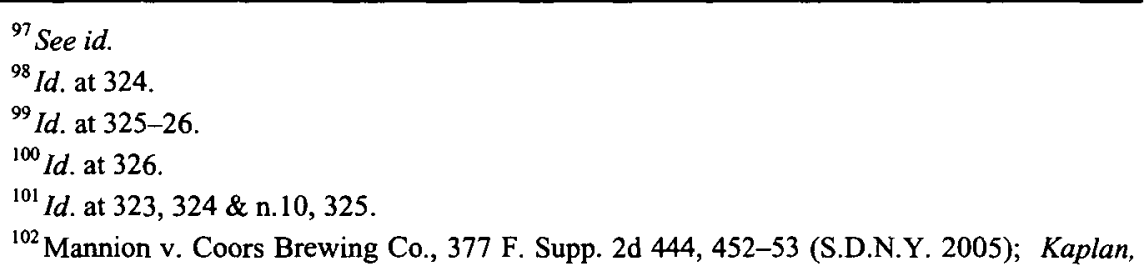

$133 \mathrm{~F}$ : Supp. 2d at 323-24 (applying scènes à faire doctrine to visual works).

${ }^{103}$ Mannion, 377 F. Supp. 2d at 457. 
[T] he line itself is meaningless because the conceptual categories it purports to delineate are ill-suited to the subject matter ....

The idea/expression distinction arose in the context of literary copyright. For the most part, the Supreme Court has not applied it outside that context....

In the visual arts, the distinction breaks down .... "[O]ne cannot divide a visual work into neat layers of abstraction in precisely the same manner one could with a text ...."

... [L]ittle is gained by attempting to distinguish an unprotectible [sic] "idea" from its protectible [sic] "expression" in a photograph or other work of visual art ....

$\ldots$ The idea/expression distinction in photography, and probably the other visual arts, thus achieves nothing ... $\ldots$ [and] is not useful or relevant. ${ }^{104}$

The Mannion opinion preserves the creative original components of photography and original combinations of unprotectable components that are meant to be protected under the holdings of Feist and Sarony. ${ }^{105}$ It accomplishes this by limiting the application of the idea-expression distinction in cases involving visual works and rejecting the expansive application of the merger and scènes à faire doctrines to visual works.

\section{EFFECTS OF THE EXPANDING APPLICATION OF THE MERGER AND SCÈNES A FAIRE DOCTRINES TO VISUAL WORKS}

Sadly, the courts have not been content to limit the application of the merger and scènes à faire doctrines to literary or dramatic settings. Instead, courts have applied these doctrines to claims of infringement of visual works wherein the elements of visual works that are claimed to be unprotected under these doctrines are filtered out and purposefully ignored

${ }^{104}$ Id. at 458-59, 461 (quoting Jon O. Newman, New Lyrics for an Old Melody: The Idea/Expression Dichotomy in the Computer Age, 17 CARDOZo ARTS \& ENT. L.J. 691, 698 (1999)) (footnotes omitted).

${ }^{105}$ Id. at 461-62; Sarony v. Ehrich 28 F. 79, 80 (C.C.S.D.N.Y. 1886). See generally Feist Publ'ns, Inc. v. Rural Tel. Serv. Co., 499 U.S. 340 (1991). 
when comparing a competing work against the original in a test of substantial similarity. ${ }^{106}$ The result in far too many cases is that visual works are reduced down to nothing, which further results in the award of summary judgment or judgment as a matter of law for the defendant before the finder of fact even gets a chance to make an intrinsic evaluation of the substantial similarity of the two works. ${ }^{107}$

This section presents the law of each circuit regarding the merger doctrine and scènes à faire doctrine in evaluating substantial similarity of two visual works. I will present the circuits favoring an expansive interpretation of the two doctrines first, followed by the circuits that have a more a circumscribed approach to the application of the merger and scènes a faire doctrines to visual works. In one instance, I will present the circuits out of order for the reason that the Ninth Circuit's jurisprudence on the issue reveals the problem I am analyzing in the starkest focus.

\section{A. Circuits With an Expansive View of the Application of the Merger and Scènes à Faire Doctrines to Visual Works}

\section{First Circuit}

The First Circuit presents a relevant starting point for this discussion. In Yankee Candle Co. v. Bridgewater Candle Co., ${ }^{108}$ the First Circuit affirmed and endorsed the substantial similarity test applied by the lower court, the District of Massachusetts. ${ }^{109}$ The case involved the comparison of pictorial labels for scented candles. ${ }^{110}$ The District of Massachusetts applied the

${ }^{106}$ The most common formulation of the test is called the abstraction-filtration-comparison test, which is traced to Computer Associates International, Inc. v. Altai, Inc., where the court applied the abstraction-filtration-comparison test in the evaluation of similarity of merged and scènes à faire elements of computer programs. 982 F.2d 693, 706-07 (2d Cir. 1992).

${ }^{107}$ E.g., Yankee Candle Co. v. Bridgewater Candle Co., 259 F. 3d 25 (1st Cir. 2001).

${ }^{108}$ Id.

${ }^{109}$ Id. at 32 . The prevailing law on substantial similarity is to subject the work to two tests: an extrinsic similarity test (sometimes called probative similarity test) in which the ideas behind the two works and expressions of those ideas are evaluated for evidence of probable copying, and an intrinsic similarity test (sometimes called substantial similarity test) in which a non-expert, ordinary observer is to determine the extent or substantiality of the copying. See id. at 33; Dam Things from Den. v. Russ Berrie \& Co., 290 F.3d 548, 562 \& nn.19-20 (3d Cir. 2002); Laureyssens v. Idea Group, Inc., 964 F.2d 131, 140 (2d Cir. 1992). The two step nature of the analysis is traced to Amstein v. Porter, 154 F.2d 464, 468-69 (2d Cir. 1946).

${ }^{110}$ Yankee, 259 F.3d at 32. 
merger doctrine and scènes à faire doctrine to dissect the Yankee labels and remove much of their contents from the intrinsic similarity analysis: the rectangular shape, the gold border, the small rectangular center box containing the fragrance name, the "full-bleed" style of photography (where the picture extends to the edges of the labels), and, in general, the photographic representation of fruits, flowers, plants, and scented objects on the labels. ${ }^{11}$ All of these were claimed to be scènes à faire elements, merged elements, or elements that incorporated public domain features. ${ }^{112}$

On appeal, Yankee made the argument that this application ignored the fact that there are myriad ways to photograph fruit, flowers, plants, and scented objects and combine them in an attractive way by making artistic choices ${ }^{113}$ much in the same way that Napoleon Sarony in the Sarony case had to make artistic choices in his photographing of Oscar Wilde. ${ }^{114}$ Yankee argued for a test of intrinsic similarity that allowed the finder of fact to consider the "total look and feel" of the label. ${ }^{15}$ After all, it is black letter copyright law that a creative combination of unprotected elements can obtain protection under copyright law ${ }^{116}$ and such a combination deserves to be regarded in the substantial similarity evaluation. ${ }^{117}$

The First Circuit rejected each argument. The court accepted the fact that Yankee had proved that Bridgewater copied the labels; ${ }^{118}$ yet it affirmed summary judgment for Bridgewater, stating that "even if Bridgewater actually copied Yankee's labels, the merger doctrine operates so that no reasonable juror could have found Bridgewater's labels to be 'substantially similar' to those of Yankee."119 The court's rendering of the merger doctrine held that:

Some ideas admit of only a limited number of expressions. When there is essentially only one way to express an idea, the idea and its expression are inseparable and copyright is

${ }^{11 \mathrm{I}}$ Yankee Candle Co. v. Bridgewater Candle Co., 99 F. Supp. 2d 140, 143-45, 148 (D. Mass. 2000).

${ }^{112}$ Id. at $145-46$.

${ }^{113}$ Yankee, 259 F.3d at 35.

${ }^{114}$ Sarony v. Ehrich, 28 F. 79, 80 (C.C.S.D.N.Y. 1886).

${ }^{115}$ See Yankee, 259 F.3d at 32.

${ }^{116}$ Feist Publ'ns, Inc. v. Rural Tel. Serv. Co. Inc., 499 U.S. 340, 348 (1991).

${ }^{117}$ See Yankee, 259 F.3d at 32.

${ }^{118}$ Id. at 33.

${ }^{119} \mathrm{Id}$. 
no bar to copying that expression. [Even] [w]hen the idea and its expression are not completely inseparable, there may still be only a limited number of ways of expressing the idea. ${ }^{120}$

The court stated that in light of the merger doctrine's application in the case of depictions of items found in nature or in everyday life, ${ }^{121}$ the plaintiff must bear a "heavy burden" of showing near identity between the two works. ${ }^{122}$ Finding it impossible for a jury to find that kind of "near identity," the court affirmed the trial court's decision to take the issue away from the jury. ${ }^{123}$

The expansive application of the merger and scènes à faire doctrines was also affirmed in Matthews v. Freedman. ${ }^{124}$ The trial court refused to compare the common elements of a souvenir $t$-shirt bearing the logo "Someone Went to Boston and got me this shirt because they love me Very much" ${ }^{125}$ surrounded by a sailboat and a lobster with a competing souvenir $\mathrm{t}$-shirt bearing the logo "Someone Who Loves Me Went to Boston and Got Me this Shirt" also surrounded by a sailboat and a lobster. ${ }^{126}$ The Court of Appeals admitted that the case presented a problem where:

An alleged infringing work taken as a whole may seem "substantially similar" to the copyrighted work taken as a whole, but the impression of similarity may rest heavily upon similarities in the two works as to elements that are

${ }^{120}$ Id. at 36; see Morrissey v. Procter \& Gamble Co., 379 F.2d 675, 678-79 (1st Cir. 1967) (rules of a contest were so simple they merge with the expression of the rules). But see John G. Danielson, Inc. v. Winchester-Conant Props., Inc., 322 F.3d 26, $42-44$ (1st Cir. 2003) (holding that the merger doctrine was inapplicable to architectural drawings where a restrictive covenant made one method of developing the site legally easier and cheaper than others, but it did not transform the drawings into the only physically possible means to express ideas for such development).

${ }^{121}$ Yankee, 259 F.3d at 36 (citing Concrete Mach. Co. v. Classic Lawn Ornaments, Inc., 843 F.2d 600, 608-11 (1 st Cir. 1988) (depicting deer in lawn ornaments); Leigh v. Warner Bros., Inc., 212 F.3d 1210, 1214-16 (11th Cir. 2000) (depicting a Bird Girl statute relating to the book and film Midnight in the Garden of Good and Evil); Herbert Rosenthal Jewelry Corp. v. Kalpakian, 446 F.2d 738, 739 (9th Cir. 1971) (depicting a jeweled bee)).

\footnotetext{
${ }^{122}$ Yankee, 259 F.3d at 36.

${ }^{123}$ Id. at $36-37$.

${ }^{124} 157$ F.3d 25 (1st Cir. 1998).

${ }^{125}$ Id. at 26 (random capitalization of words shown is the same as in the original).

${ }^{126}$ Id. Each shirt had one or more other iconic symbols of Boston that were dissimilar.
} 
not copyrightable-because those elements are the underlying ideas, or expressions that are not original with the plaintiff, or for some like reason. ${ }^{127}$

Each shirt had lettering drawn in a childish style, but the court affirmed that the choice of rendering letters in a childish style was inevitable and necessary. ${ }^{128}$ The use of similar iconic symbols of Boston was also inevitable and necessary. ${ }^{129}$ The fact that the words were so similar was ignored because the court found that it was only the idea behind the words that was similar. ${ }^{130}$ Rejecting the possibility that the two creators' rendering and embodiment of the ideas might in fact be one creator copying the other's embodiment of the ideas, and that improper copying is what the court should be considering, the trial court instead approved the procedure of expelling any part of the shirt that might, in fact, embody a stock image or idea relating to Boston and people who buy t-shirts for loved ones. ${ }^{131}$ The First Circuit declared, in effect, that the initial creator's copyright is so thin that only a slavish copy-a complete, $100 \%$ true copy produced by scanning or photocopying or photographic reproduction of the first author's creation-would violate the first author's copyright in her work. ${ }^{132}$

The most puzzling part of the First Circuit's analysis is that the court recognizes that "entirely unoriginal expressions taken from others might sometimes be combined in a way that gives rise to a new protectible [sic] expression." $" 133$ The court also acknowledged that the ordinary observer (intrinsic similarity) test in copyright precludes copying if the second author's works are to the average observer substantially similar in design and overall aesthetic appeal. ${ }^{134}$ By dissecting out of the work all of the elements that are supposedly merged with their underlying ideas or that embody stock, or scènes à faire, elements (leaving aside the fact that there are myriad ways to embody a stock image or idea in a visual work), the court leaves little or nothing from the original author's composition to

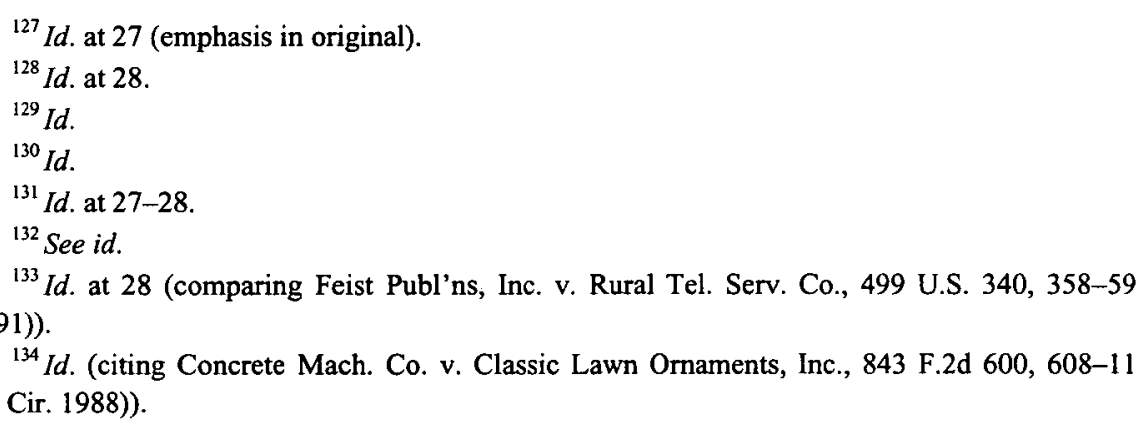


compare to the alleged plagiarist's work. The judgment in favor of the plagiarist was affirmed. ${ }^{135}$ To add insult to injury, the court also affirmed the award of $\$ 25,000$ in attorneys' fees to the defendant because in the court's estimation the original artist chose to bring a weak, nonfrivolous, case and argued for an unreasonable extension of copyright protection. ${ }^{136}$

In these two cases, the First Circuit's expansive application of the merger and scènes à faire doctrines took the cases away from the jury. Average observers were not allowed to compare the works. The court failed to acknowledge that the plaintiffs might have combined unprotectable elements in a creative, original way, producing a complete and protectable construct that would be attractive for copying - even in the face of fairly certain evidence that the defendants did copy plaintiff's creation. After stripping away what the judges thought were stock images and merged elements, the court saw that little or nothing was left to plaintiffs' works in both cases. Thus, with nothing to show to the average observers, there can be nothing substantial that could have been copied by the defendant. Summary judgment or judgment as a matter of law in favor of the alleged plagiarist is the inevitable result.

\section{Ninth Circuit}

The Ninth Circuit's interpretation of the merger and scènes à faire doctrines has also led to the destruction and reduction of visual works at the intrinsic similarity stage of the analysis. ${ }^{137}$ The results of this analysis come into starkest focus in Satava v. Lowry. ${ }^{138}$ The court in Satava held that there are obstacles to enforcing a copyright in a work that portrays or depicts a natural object, in this case, a jellyfish. ${ }^{139}$ Using the intrinsic similarity test, the Ninth Circuit has held that unprotectable elements must be removed and discarded before the finder of fact is to perform the lay person intrinsic similarity analysis. ${ }^{140}$ Guided by the principle that there must be only one way to depict a jelly fish in a visual media, the Ninth Circuit intentionally ignored the evidence collected by the district court in the case showing that

\footnotetext{
${ }^{135} I d$. at 29.

${ }^{136} \mathrm{Id}$.

${ }^{137}$ See generally Satava v. Lowry, 323 F.3d 805 (9th Cir. 2003).

${ }^{138}$ See id. at 810.

${ }^{139}$ See id. at 810-813.

${ }^{140}$ See id.; see also Ets-Hokin v. Skyy Spirits Inc., 323 F.3d 763, 766 (9th Cir. 2003); Aliotti v. R. Dakin \& Co., 831 F.2d 898, 901 (9th Cir. 1987).
} 
there were literally hundreds of ways to depict jellyfish, including the multiple ways produced by Satava and the many other ways attempted by Lowry and his associates. ${ }^{141}$ In fact, the court used this information against the plaintiff by stating that it had examined dozens of photographs of glassin-glass jellyfish and found them all to be substantially similar. ${ }^{142}$ The court stated, "[t]hough none of the sculptures are identical, all of them are substantially similar. They differ only insofar as an artist has added or omitted some standard element."

The belief that there is only one way to depict jellyfish in this art form would have allowed the court to find the idea of a jellyfish and the expression of the jellyfish merged. However, the court did not reach the merger issue in favor of a vigorous application of the scènes à faire doctrine as the court held that every depiction of jellyfish is an amalgam of unprotected standard images from nature. ${ }^{144}$ The result of the analysis was the holding that an artist who produces a work that portrays or depicts a natural object will have an unenforceable copyright. ${ }^{145}$ True, the court allows that a paper-thin copyright might exist, but it anticipates that no combination of unprotectable elements related to natural objects will add up to a substantial amount when found in the same proportion in the plagiarist's work. ${ }^{146}$

The road to Satava in the Ninth Circuit was a long and uneven one. Until recently, the circuit was not known for its hostility to the original contributions of artists working in visual media. It may come as a surprise to some that the Ninth Circuit is recognized as establishing the "total concept and feel" standard in the analysis of intrinsic similarity of visual works that usually coincides with a restrictive view of the merger and scènes à faire doctrines. Sid \& Marty Krofft Television Products, Inc. v.

${ }^{141}$ See Satava v. Lowry, No. CIV-S-01-701 GEB/DAD, slip op. at *2-4, 11 (E.D. Cal. June 12,2002 ) (Lowry affirmed that there were "a myriad of ways that one could portray jellyfish in glass art;" Lowry's associate described and produced multiple shapes and forms for jellyfish in glass art; Satava produced approximately 300 unique and individual glass-in-glass sculptures of jellyfish a month).

${ }^{142}$ See Satava, 323 F.3d at 812.

${ }^{143}$ Id. at 812 n.5.

${ }^{144}$ See id. at $810-11,812$ \& $\mathrm{n} .5$ (finding it unnecessary to reach the merger doctrine issue as it had produced the same effect under the rationale that Satava could not claim a monopoly in any realistic depictions of jellyfish, and that any depiction of jellyfish must necessarily be a combination of unprotectable standard images).

${ }^{145}$ Id. at 811 .

${ }^{146}$ See id. at 812. 
McDonald's Corp. brought the phrase to the two prong extrinsic and intrinsic similarity test. ${ }^{147}$ The first prong in the analysis was an extrinsic analysis to determine similarity in the general ideas underlying the expression in the two works. ${ }^{148}$ Because some material that would appear to be similar would be unprotected under the originality and idea-expression restrictions (public domain themes and concepts, merged ideas, scènes $\dot{a}$ faire), the court instructed that analytic dissection is appropriate under extrinsic analysis so that protected expression in the first work can be compared with allegedly similar expression in the second work. ${ }^{149}$ Expert witnesses can aid in determining when components of the work are similar. ${ }^{150}$ The Ninth Circuit indicated that in many cases the extrinsic similarity may be determined by the court as an issue of law. ${ }^{151}$

The second part of the analysis was an intrinsic test that compared the substantiality of the similarity in the expression of both works. ${ }^{152}$ The intrinsic similarity test was to be determined by the ordinary reasonable person. ${ }^{153}$ The finder of fact was to examine the works as a whole to evaluate their "total concept and feel." "154 Therefore, analytic dissection at this stage of analysis was prohibited. ${ }^{155}$

${ }^{147}$ See Sid \& Marty Krofft Television Prods., Inc. v. McDonald's Corp., 562 F.2d 1157, 1164-67 (9th Cir. 1977). The case involved the claim of the creators of the seemingly innocent children's show, H. R. Pufnstuf, against McDonald's, who allegedly copied the central puppet characters from Pufnstuf to populate the fanciful McDonaldland with Mayor McCheese, Grimace, and Hamburglar. Later, Pufnstuf was more closely examined for its marijuana references (e.g., puffing stuff; H.R. for hand rolled), which was held to be consistent with McDonald's interest in the Pufnstuf characters to attract not only hungry children who are fond of larger than life puppets with oversized heads, but also stoners with the munchies. See http://www.cannabisculture.com/articles/2926.html (last visited Mar. 22, 2006).

${ }^{148}$ Sid \& Marty Krofft, 562 F.2d at 1164.

${ }^{149} I d$.

${ }^{150} \mathrm{Id}$.

${ }^{151} I d$.

${ }^{152} I d$.

${ }^{153} \mathrm{Id}$.

${ }^{154}$ Id. at 1167 (Sid \& Marty Krofft gets the credit for working this standard into the intrinsic similarity test even though the opinion acknowledges Roth Greeting Cards v. United Card Co., 429 F.2d 1106, 1110 (9th Cir. 1970), as the origin of the four word phrase, "total concept and feel".)

${ }^{155}$ Id. at 1164 (quoting Twentieth Century Fox-Film Corp. v. Stonesifer, 140 F.2d 579, 582 (9th Cir. 1944)) ("The two works involved in this appeal should be considered and tested, not hypercritically or with meticulous scrutiny, but by the observations and impressions of the average reasonable reader and spectator."). 
The two-part test was applied to realistic depictions of animals in Kamar International, Inc. v. Russ Berrie \& Co. ${ }^{156}$ Far from placing insurmountable obstacles in the face of the creator of such works, in 1981 the Ninth Circuit was positively offended by the proposition that realistic depictions of animals could not be original enough to be copyrightable: "Berrie makes the novel contention that realistic depictions of live animals are not copyrightable .... We find no authority for Berrie's proposition. Anyone can copyright anything, if he adds something original to its expression." "157 The Ninth Circuit reversed the district court in part for using the analytic dissection test in the intrinsic similarity prong of the two part substantial similarity test. ${ }^{158}$

The court started to turn the corner on the merger and scènes a faire doctrines in Aliotti v. R. Dakin \& Co. ${ }^{159}$ In a case involving depictions of actual creatures (dinosaurs), the court reconsidered the Sid \& Marty Krofft formulation of the intrinsic similarity test so as to better accommodate the merger doctrine. ${ }^{160}$ The court noted:

Appellants argue correctly that the district court's determination as to substantial similarity of expression relied incorrectly on the analytic dissection of the dissimilar characteristics of the dolls. Similarity of expression exists only when "the total concept and feel of the works" is substantially similar. Dissection of dissimilarities is inappropriate because it distracts a reasonable observer from a comparison of the total concept and feel of the works. $^{161}$

The subtle insertion of the word dissimilarities is important because the court makes a point about dissection of similarities in an effort to open the door to the merger doctrine in visual media cases. ${ }^{162}$ The court held that:

To the extent that it is necessary to determine whether similarities result from unprotectable expression, it is

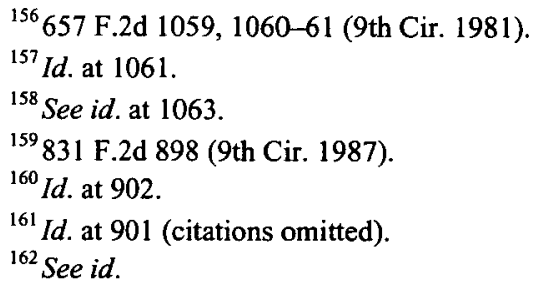


appropriate under Krofft's intrinsic test to perform analytic dissection of similarities. Although even unprotectable material should be considered when determining if there is substantial similarity of expression, no substantial similarity may be found under the intrinsic test where analytic dissection demonstrates that all similarities in expression arise from the use of common ideas. ${ }^{163}$

Thus, dissection entered the intrinsic portion of the similarity test, albeit after the "total concept and feel" of the works as a whole was evaluated by the finder of fact. ${ }^{164}$ If there was no substantial, intrinsic similarity as to the works as a whole, the case was closed; but if there was substantial, intrinsic similarity as to the works as a whole, the similar features of the works could then be dissected and separately analyzed to make sure that all similarities were not as to unprotected elements. ${ }^{165}$

Aliotti's innovation was not limited to taking down the total concept and feel standard of intrinsic similarity analysis. Alliotti also marks the expanded application of the merger doctrine and scènes à faire doctrine in visual media cases in the Ninth Circuit. ${ }^{166}$ Courts who are intent on expanding the application of the doctrine find it hard to accomplish this in the face of the total concept and feel standard. ${ }^{167}$ The total concept and feel standard finds its support in the bedrock copyright law stating that original combinations of uncopyrightable components can be protected. ${ }^{168}$ Therefore, the evaluator must look at the total combination, not a stripped down combination when comparing it to the alleged plagiarist's work. By shelving the total concept and feel test, and stressing the dissection and filtration of allegedly merged and scènes à faire material, the court creates the opportunity for summary disposition of the suit-the more material that is stripped away from plaintiff's work, the more comfortable the court will be with finding as a matter of law that no average person could find the two works to be substantially similar as to the few items remaining in the plaintiff's work. If a court takes the total concept and feel standard seriously, it almost guarantees a jury trial unless the two works in their

\footnotetext{
${ }^{163} \mathrm{Id}$. (emphasis in original) (citations omitted).

${ }^{164}$ See id. at $901-02$.

${ }^{165}$ See id.

${ }^{166}$ See id.

${ }^{167}$ See id.

${ }^{168}$ See Feist Publ'ns, Inc. v. Rural Tel. Serv. Co., 499 U.S. 340, 348 (1991).
} 
entirety are simply and manifestly dissimilar. Taking away a stripped down plaintiff's creation from the jury is an easier call than making an aesthetic determination that an average person could not find substantial similarity in the two works as a whole.

After Aliotti opened the door of the intrinsic test to the merger doctrine, the total part of the total concept and feel standard was not long for the Ninth Circuit's world. The wheels came off dramatically when the circuit had to face visual elements of computer programs in a monumental struggle between Apple and Microsoft for the rights of Microsoft to develop the graphical user interface (GUI) that became Windows 2.03 and 3.0 and opened the door to the release of Windows $95 .{ }^{169}$ The facts of the case should have produced a narrow holding: Apple had entered into a license agreement with Microsoft that allowed Microsoft to adapt many of the graphical user interface features of Apple's operating system into Windows 2.03. ${ }^{170}$ As a contract case, the outcome of the case is unremarkable: In the core provision of the license, Apple allowed its main competitor to copy and adapt many attractive elements of Apple's GUI in exchange for the right to use and adapt any attractive GUI features Microsoft developed during the license term. ${ }^{171}$ Apple came to regret the scope of the contract because it helped Microsoft to develop its product into the marketdominating operating system that we know today. ${ }^{172}$ However, the district court and the Ninth Circuit were forced to address issues beyond the contract's interpretation. ${ }^{173}$ Apple raised tangential copyright issues as to the size, placement, and appearance of certain icons and certain features of

${ }^{169}$ The struggle produced six district court opinions: Apple Computer, Inc. v. Microsoft Corp., 709 F. Supp. 925 (N.D. Cal. 1989), aff'd, 35 F.3d 1435 (9th Cir. 1994) (Apple 1); Apple Computer, Inc. v. Microsoft Corp., 717 F. Supp. 1428 (N.D. Cal. 1989), aff'd, 35 F.3d 1435 (9th Cir. 1994) (Apple II); Apple Computer, Inc. v. Microsoft Corp., 759 F. Supp. 1444 (N.D. Cal. 1991), aff'd, 35 F.3d 1435 (9th Cir. 1994) (Apple III); Apple Computer, Inc. v. Microsoft Corp., 779 F. Supp. 133 (N.D. Cal. 1991), affd, 35 F.3d 1435 (9th Cir. 1994) (Apple IV); Apple Computer, Inc. v. Microsoft Corp., 799 F. Supp. 1006 (N.D. Cal. 1992), aff'd, 35 F.3d 1435 (Apple V); Apple Computer, Inc. v. Microsoft Corp., 821 F. Supp. 616 (N.D. Cal. 1993), aff'd, 35 F.3d 1435 (9th Cir. 1994) (Apple VI). The end result is the Ninth Circuit's opinion in Apple Computer, Inc. v. Microsoft Corp., 35 F.3d 1435 (9th Cir. 1994).

${ }^{170}$ Apple, 35 F.3d at 1438.

${ }^{171}$ See id. at 1440 \& n. 8 (Other provisions pertained to the delay of the release of Microsoft's Excel product for platforms other than Apple's Macintosh platform and the development of a new version of Microsoft's Word product for Apple's Macintosh platform.).

${ }^{172}$ See id.

${ }^{173}$ Id. at $1442-47$. 
the design and appearance of the "windows" on the GUI that were not sufficiently addressed in the license between the parties. ${ }^{174}$ It is in this discussion of copyright law by the Ninth Circuit that an alarming interpretation of the merger and scènes a faire doctrines in the context of visual works was spawned.

As in other computer program cases, the district court was shaken by the possibility that programs might be subject simultaneously to the limiting doctrines of originality, functionality, standardization, scènes à faire, and merger. ${ }^{175}$ As a result, the district court dissected the disputed features of the Macintosh and Windows interfaces based on a list of similarities submitted by Apple to decide which were protectable. ${ }^{176}$ Thereafter, the district court applied the limiting doctrines of originality, functionality, standardization, scènes à faire, and merger to arrive at a finding of no copying of protectable elements in Windows 2.03 or 3.0. ${ }^{177}$ The court then held that the Windows 2.03 and 3.0 works as a whole would be compared with Apple's works for virtual identity. ${ }^{178}$ When Apple declined to oppose motions for summary judgment of noninfringement for lack of virtual identity, however, judgments in favor of Microsoft were entered. ${ }^{179}$

The Ninth Circuit approved of the dissection and discard of all allegedly unprotectable elements. ${ }^{180}$ First, it summarized Apple's objections to the district court's ruling as follows:

Apple makes a number of related arguments challenging the district court's copyright analysis. It contends that the district court deprived its works of meaningful protection by dissecting them into individual elements and viewing each element in isolation. Because the Macintosh GUI is a dynamic audiovisual work, Apple argues that the "total concept and feel" of its works-that is, the selection and arrangement of related images and their animation-must be compared with that of the Windows ... GUIs for substantial similarity. Apple further

\footnotetext{
${ }^{174}$ See id.

${ }^{175} I d$.

${ }^{176} \mathrm{Id}$. at 1438.

${ }^{177}$ See id.

${ }^{178}$ Id.

${ }^{179} \mathrm{Id}$.

${ }^{180}$ See id. at 1439.
} 
asserts that in this case, the court had no occasion to dissect its works into discrete elements because Microsoft and HP [Hewlett Packard, Microsoft's licensee] virtually mimicked the composition, organization, arrangement and dynamics of the Macintosh interface, as shown by striking similarities in the animation of overlapping windows and the design, layout and animation of icons. Apple also argues that even if dissection were appropriate, the district court should not have eliminated from jury consideration those elements that are either licensed or unprotected by copyright. Though stated somewhat differently, all of these contentions boil down to the same thing: Apple wants an overall comparison of its works to the accused works for substantial similarity rather than virtual identity. ${ }^{181}$

In Apple, The Ninth Circuit knew it was evaluating a complex visual work rather than program codes registered as a literary work, but it was not ready to allow a total look and feel analysis of the overall graphical user interface of Apple compared to Microsoft's GUI. ${ }^{182}$ The Ninth Circuit stated that the law of the circuit had changed in Brown Bag Software v. Symantec Corp., and that the intrinsic similarity test now included an analytic dissection and rejection of components before evaluating the less than total concept and some of the feel of the two programs. ${ }^{183}$ In fact, the Brown Bag court had not held this and in fact had not reached the issue. ${ }^{184}$ In any event, Apple drove a stake through the heart of evaluation of visual works: There would be a two stage test with analytical dissection at each stage and rejection of parts that were supposedly subject to the merger and

${ }^{181}$ Id. at 1442 (emphasis in original).

${ }^{182}$ See id. at $1442-43$.

${ }^{183}$ See id. at 1443 (citing Brown Bag Software v. Symantec Corp., 960 F.2d 1465, 1475-76 (9th Cir. 1992)).

${ }^{184}$ Brown Bag Software, 960 F.2d at 1475-76. Apple also cited Shaw v. Lindhein, an opinion that in dicta made the remarkably backwards statement that the intrinsic similarity evaluation of visual works such as were involved in Aliotti (stuffed dinosaurs) and Kalpakian (bee shaped jewelry) was well suited for determination by the court on a summary judgment motion when the merger doctrine is alleged to be involved, but the same could not be said for literary works. 919 F.2d 1353, 1360-61 (9th Cir. 1990). The Shaw court held that if a showing of similarity is made on the extrinsic evaluation of a literary work, it is wrong for the court to resolve the intrinsic evaluation of the work on a summary judgment motion. Id. at 1361. Instead, the finder of fact must make the subjective evaluation of the literary work. Id. 
scènes à faire doctrines. ${ }^{185}$ There would be no subjective evaluation of the total concept and feel of any visual work that allegedly merged with its underlying ideas (there being a drastically limited number of ways of depicting the idea visually) or allegedly embodied stock images that must be copied in order to depict the idea. ${ }^{186}$

In Cavalier v. Random House, Inc., Apple's holding was interpreted to mean that in visual art cases, the court is to filter out unprotectable elements in both the extrinsic and intrinsic similarity tests. ${ }^{187}$ Oddly, the court did not think that this bears on the ability of an artist or author to receive protection for original combinations of unprotectable elements as described in Feist. ${ }^{188}$ Nor did the court believe that this prevents the intrinsic similarity evaluator from considering the total concept and feel of the two works. ${ }^{189}$ The court stated:

This does not mean that at the end of the day, when the works are considered under the intrinsic test, they should not be compared as a whole. Nor does it mean that infringement cannot be based on original selection and arrangement of unprotected elements. However, the unprotectable elements have to be identified, or filtered, before the works can be considered as a whole. ${ }^{190}$

The end of this line of thinking is a case like Satava. ${ }^{191}$ But along the way we encounter Ets-Hokin v. Skyy Spirits Inc., a case involving commercial photography. ${ }^{192}$ The court was receptive to the argument that there were only a drastically limited number of ways of depicting a Skyy Vodka bottle in photography, and thus used the merger doctrine to strip away the apparently similar features of plaintiff's and defendant's photography. ${ }^{193}$ What similarities were left after the merger analysis were

${ }^{185}$ See Apple, 35 F.3d at $1442-47$.

186 See id.

${ }^{187} 297$ F.3d 815, 825-26 (9th Cir. 2002) ("The basic mode of analysis for comparison of the literary elements applies to comparison of the art work. As with literary works, unprotectible [sic] elements should not be considered when applying the extrinsic test to art work.").

${ }^{188}$ See Feist Publ'ns, Inc. v. Rural Tel. Serv. Co., 499 U.S. 340, 348 (1991).

${ }^{189}$ See Cavalier, 297 F.3d at 826.

${ }^{190}$ Id. (quoting Apple Computer, Inc. v. Microsoft Corp., 35 F.3d 1435, 1446 (9th Cir. 1994)).

${ }^{191}$ See generally Satava v. Lowry, 323 F.3d 805 (9th Cir. 2003).

${ }^{192}$ See generally 323 F.3d 763 (9th Cir. 2003).

${ }^{193}$ See id. at 765-66 ("Though the Ets-Hokin and Skyy photographs are indeed similar, their 
rejected as scènes à faire of commercial photography. ${ }^{194}$ Plaintiff argued that application of the merger doctrine and scènes à faire doctrine to photography contradicted the established law regarding the originality and creativity of photography as an artistic medium. ${ }^{195}$ The court failed to see the point; it held that photography certainly can achieve the level of originality required for copyright protection but still be susceptible to the merger and scènes à faire doctrines because similarities in photographs depicting the same subject necessarily flow from the subject matter and such similarities are, "as a practical matter, indispensable, or at least standard." 196 The Ninth Circuit affirmed the lower court's grant of summary judgment to defendant. ${ }^{197}$

\section{Fifth Circuit}

In evaluating computer programs, the Fifth Circuit embraces the abstraction-filtration test, more popularly known as the abstractionfiltration-comparison test. ${ }^{198}$ The goal of the test is to separate out unprotectable elements from the original work before the finder of fact makes a comparison with the allegedly infringing work. ${ }^{199}$ In practice, the first step of the test is dissection, for only when the parts of a program or other work (starting with object code, source code, subroutines, and program structure, and working up to an articulation of the program's ultimate function) are dissected can they be abstracted to their appropriate level of generality. ${ }^{200}$ Then each dissected part can be examined separately to see if any part is essentially composed of uncopyrightable ideas,

similarity is inevitable, given the shared concept, or idea, of photographing the Skyy bottle.").

${ }^{194}$ See id. at 766 (citing Apple, 35 F.3d at 1442).

${ }^{195}$ See id. at 765 (citing Burrow-Giles Lithographic Co. v. Sarony, 111 U.S. 53, 58 (1884))

${ }^{196}$ See id. at 765-66 (citing Apple, 35 F.3d at 1444).

${ }^{197}$ Id. at 764 .

${ }^{198}$ See Computer Mgmt. Assistance Co. v. Robert F. DeCastro, Inc., 220 F.3d 396, 400 (5th Cir. 2000); see also Nichols v. Universal Pictures Corp., 45 F.2d 119, 121 (2d Cir. 1930) (first recognizing the abstraction test); Eng'g Dynamics, Inc. v. Structural Software, Inc., 26 F.3d 1335, 1342-43 (5th Cir. 1994) (discussing the abstraction filtration comparison test); Gates Rubber Co. v. Bando Chem. Indus., Ltd., 9 F.3d 823, 834 (10th Cir. 1993) (discussing the abstraction filtration comparison test); Computer Assocs. Int'l, Inc. v. Altai, Inc., 982 F.2d 693, 706 (2nd Cir. 1992) (discussing the abstraction filtration-comparison test).

${ }^{199}$ Computer Mgmt. Assistance Co., 220 F.3d at 401.

${ }^{200}$ See id; Eng'g Dynamics, 26 F.3d at 1342-43; Gates Rubber, 9 F.3d at 834; Altai, 982 F.2d at 706-07. 
processes, facts, public domain information, merged material, or scènes $\grave{a}$ faire material. ${ }^{201}$ Those parts that fit one of these categories are thrown out (filtered out in the terms of the test), but the end result is the same: The finder of fact never is to see them or consider them when comparing the original work with the allegedly infringing work. ${ }^{202}$ To the extent that this stripping down process renders the original work an incomplete chop-shop jalopy that has alternately missing doors and windows, so be it. Under the abstraction-filtration test, the finder of fact may never see the original work as a whole and evaluate its total concept and feel.

As rooted as the abstraction-filtration test is in computer cases, the Fifth Circuit has been inconsistent in applying the test in other factual situations. In Positive Black Talk Inc. v. Cash Money Records Inc., ${ }^{203}$ the court held that at the probative similarity stage, ${ }^{204}$ two competing musical works should be compared as a whole and "in their entirety, including both protectable and unprotectable elements." ${ }^{205}$ As in most jurisdictions, the Fifth Circuit, in the absence of proof of actual copying, requires an initial showing of (1) defendant's access to the original work, and (2) a showing of probative similarity of the two works to indicate probable copying. ${ }^{206}$ Then, in the absence of defendant's proof of independent creation, the works are evaluated for substantial similarity. ${ }^{207}$ Even at the substantial similarity stage, the court affirmed the jury instruction that the "total concept and feel" of the two works must be evaluated. ${ }^{208}$

Lower courts in the Fifth Circuit have not been as expansive in their application of the merger and scènes à faire doctrines in visual art cases. In Maggio v. Liztech Jewelry, the Eastern District of Louisiana considered the merger doctrine in the context of evaluation of decorative jewelry. ${ }^{209}$ The

${ }^{201}$ See Altai, 982 F.2d at 706-07; Computer Mgmt. Assistance, 220 F.3d at 401; Eng'g Dynamics, 26 F.3d at 1342-44; Gates Rubber, 9 F.3d at 834-35.

${ }^{202}$ See Altai, 982 F.2d at 707-10; Computer Mgmt. Assistance, 220 F.3d at 402; Eng'g Dynamics, 26 F.3d at 1344-45; Gates Rubber, 9 F.3d at 836, 841.

${ }^{203} 394$ F.3d 357 (5th Cir. 2004).

${ }^{204}$ This is held to be another wording for the "extrinsic similarity" step of the analysis, or whether the ideas underlying the original work were copied. See, e.g., id. at 373-74 \& n. 13.

${ }^{205}$ Id. at 370 n.9 (citing Fisher-Price, Inc. v. Well-Made Toy Mfg. Corp., 25 F.3d 119, 123 (2d Cir. 1994)).

${ }^{206} \mathrm{Id}$. at 368 .

${ }^{207}$ Id.

${ }^{208}$ See id. at $373-74$.

${ }^{209} 912$ F. Supp. 216, 223 (E.D. La. 1996). 
court held that the merger doctrine applies only when there is only one way to express an idea. ${ }^{210}$ Where the "idea is clearly capable of different forms of expression," the idea does not merge with any one form of expression. ${ }^{211}$ In Maggio, the court found that the jewelry pins consisting of silhouettes of natural or symbolic shapes cut from chrome and embellished with copper wire and beading obviously was only one possible expression of the idea of making jewelry based on the silhouettes of natural and symbolic forms and shapes. ${ }^{212}$ The merger doctrine took nothing away from the original creator's works. $^{213}$ Nor did the court strike away parts of the jewelry-the central part of the jewelry, the silhouette of a natural creature or symbolic shape- on the basis of the scènes à faire doctrine before allowing the finder of fact to consider the similarity of the two competing sets of jewelry. ${ }^{214}$ Instead, the jewelry was to be evaluated as a whole for a comparison of the total concept and feel of the works. ${ }^{215}$

\section{Sixth Circuit}

The Sixth Circuit is as unapologetic as the First Circuit in applying the merger and scènes à faire doctrines to visual works. The court states that "before comparing similarities between two works a court should first identify and eliminate those elements that are unoriginal and therefore

${ }^{210} I d$;; see also Veeck v. S. Bldg. Code Cong. Int'l, Inc., 293 F.3d 791, 801 (5th Cir. 2002) (en banc) (legislation enacting provision of copyrighted model code becomes part of the law, and the law cannot be copyrighted; the merger doctrine applies because the legislation is the only way to express the idea of the law).

${ }^{211}$ See Maggio, 912 F. Supp. at 223.

${ }^{212}$ See id.

${ }^{213}$ See id. at 223 n.5 (distinguishing Tabra, Inc. v. Treasures de Paradise Designs, Inc., No. C 90-0155 MHP, 1990 WL 126187 (N.D. Cal. Apr. 24, 1990) (mem.) (expression of "primitivelook" bone, stone, shell, and beads jewelry held merged with idea of the same in that there was no distinguishing arrangement of the raw materials evident in the original works) and Herbert Rosenthal Jewelry Corp. v. Kalpakian, 446 F.2d 738 (9th Cir. 1971) (expression of naturalistic jeweled bee pin held merged with idea of jeweled bee pin where pin was a lifelike representation of a natural creature and the court thought there was no unique or original arrangement of jewels)).

${ }^{214}$ See Maggio, 912 F. Supp. at 223; see also Naghi v. Europe's Finest, Inc., 114 Fed. App'x 606,607 (5th Cir. 2004) (stating that even though hemp leaves are natural objects, expression of hemp leaf Mardi Gras necklace did not merge with idea of same because hemp leaves were susceptible to multiple expressions).

${ }^{215}$ See Maggio, 912 F. Supp. at 223. 
unprotected." 216 The court states that it will be faithful to Feist which "favors an approach that involves reducing the [substantial similarity] comparison to elements that are original." 217 . In and of themselves, these statements are unremarkable-unprotectable elements should be unprotectable and unoriginal components are unprotectable. But when combined with an expansive interpretation of the merger and scènes à faire doctrines, it spells disaster for visual works that feature expressions of real world objects and entities.

The Sixth Circuit accepts the abstraction-filtration-comparison test. ${ }^{218}$ The Sixth Circuit follows the approach taken in Sturdza v. United Arab Emirates, which in turn took the test from the Tenth Circuit in Country Kids 'N City Slicks, Inc. v. Sheen, which itself borrowed from the Second Circuit in Computer Assocs. Int' $l$, Inc. v. Altai. ${ }^{219}$ Thus, the originality rubric of the Sixth Circuit is descended from computer software cases. In computer cases, the test ruthlessly filters out merged items and scènes $\dot{a}$ faire elements to avoid the situation where a programmer will corner the market on "the only and essential means," or one of the only practical and efficient ways, to accomplish a programming task using a selected computer language and targeting a selected computer hardware configuration. ${ }^{220}$ Technical and practical requirements, design standards, and appropriate methods of operation dictate programming choices rather than the creative input of the creator, and in these circumstances the copyright requirement of originality precludes broad protection of the code written by the programmer whether the rationale is expressed as lack of originality, functionality over creative design, merger of programming elements with the idea of the program's operation, or scènes à faire program elements. ${ }^{221}$

The reductionist approach manifested in the abstraction-filtration test is also manageable in functional, non-software-related situations that mimic

${ }^{216}$ Kohus v. Mariol, 328 F.3d 848, 853 (6th Cir. 2003); see also Small v. Exhibit Enters., Inc., 364 F. Supp. 2d 648, 652 (E.D. Mich. 2005).

${ }^{217}$ Kohus, 328 F.3d at 854 (citing Feist Publ'ns, Inc. v. Rural Tel. Serv. Co., 499 U.S. 340 (1991)).

${ }^{218}$ Id. at $855 \&$ n. 1 .

${ }^{219}$ See Sturdza v. United Arab Emirates, 281 F.3d 1287, 1295-96 (D.C. Cir. 2002); Country Kids 'N City Slicks, Inc. v. Sheen, 77 F.3d 1280, 1284 (10th Cir. 1996); Computer Assocs. Int'l, Inc. v. Altai, 982 F.2d 693, 706-07 (2d Cir. 1992).

${ }^{220}$ See Lexmark Int'l, Inc. v. Static Control Components, Inc., 387 F.3d 522, 534-36 (6th Cir. 2004).

${ }^{221}$ See id. 
Baker and Feist, which are the classic cases involving non-original works created to present data. ${ }^{22}$ In ATC Distribution Group, Inc. v. Whatever It Takes Transmissions \& Parts, Inc., and Tastefully Simple, Inc. v. Two Sisters Gourmet, L.L.C., the Sixth Circuit followed the approach taken in Baker and Feist by applying the originality test and merger doctrine to find that an automobile parts catalogue and standard forms produced for reporting sales tax information and other food sales customer information were uncopyrightable because they simply allow for the reporting of standard information in the auto parts business and food sales business. ${ }^{223}$ There was no creativity in the arrangement of the parts listings or parts numbers in $A T C$ nor in the line items on the forms and categories listed in Tastefully Simple that were not merged with the idea of keeping track of categories of information as a necessary part of doing business. ${ }^{224} A T C$ and Tastefully Simple are on all fours with Baker and Feist.

In a literary context, the abstraction-filtration test at least provides a framework to consider the similarity of literary works by focusing on the level of abstraction required to find that the works are the same. ${ }^{225}$ Judge Hand's process of abstraction in Nichols did not answer the question of how abstract is too abstract. ${ }^{226}$ But courts such as the Sixth Circuit are not deterred in finding that at the level of abstraction needed in the case at hand is too abstract to support an infringement claim, and the question should be taken away from the jury. ${ }^{227}$ Audio visual media, such as motion pictures and television, most often are analyzed as literary works because it is an unusual case where there is a question about actual audio and visual. copying (taping) of a motion picture, stage play, or television show outside of the de minimis use or fair use contexts. ${ }^{228}$ Instead, the abstractionfiltration test is used when an allegation is made that characters, plots, scenes, or situations are stolen from a motion picture, stage play, or

${ }^{222}$ See generally Feist Publ'ns, Inc. v. Rural Tel. Serv. Co., 499 U.S. 340 (1991); Baker v. Selden, 101 U.S. 99 (1879).

${ }^{223}$ See ATC Distribution Group, Inc. v. Whatever It Takes Transmissions \& Parts, Inc., 402 F.3d 700, 710-11 (6th Cir. 2005); Tastefully Simple, Inc. v. Two Sisters Gourmet, L.L.C., 134 Fed. App'x 1, 4-5 (6th Cir. 2005).

${ }^{224}$ Tastefully Simple, 134 Fed. App'x at 4-5; ATC, 402 F.3d at 711-12.

${ }^{225}$ See Stromback v. New Line Cinema, 384 F.3d 283, 296-300 (6th Cir. 2004); Murray Hill Publ'ns, Inc. v. Twentieth Century Fox Film Corp., 361 F.3d 312, 315-21 (6th Cir. 2004).

${ }^{226}$ See Nichols v. Universal Pictures Corp., 45 F.2d 119, 122 (2d Cir. 1930).

${ }^{227}$ See, e.g., Stromback, 384 F.3d at 297-99; Murray Hill, 361 F.3d at 315-24.

${ }^{228}$ See Stromback, 384 F.3d at 293. 
television show. ${ }^{229}$ The filtration step still works to cancel out merged elements and scènes à faire character types, plot devices, standard scenes, and common situations from literary works. ${ }^{230}$ Problems arise, however, when a test created for computer software or the reporting of factual information begins to be applied in creative, visual media cases. ${ }^{231}$

The filtration step, in the context of copying of static visual media sounds innocuous until you expand the definition of merger and scènes $\dot{a}$ faire. The Sixth Circuit in Kohus opined that latches for an outdoor play area were functional, which almost necessarily means that parts of their design are dictated by efficiency. ${ }^{232}$ Rather than seeing the situation as one in which multiple efficient original designs might be possible, the court seemed to be looking for an excuse to find that only one set of characteristics would be efficient, and thus find that those characteristics were dictated by the task. Therefore, they are unoriginal, and are unprotectable under the merger doctrine. ${ }^{233}$ Similarly, under the scènes $\dot{a}$ faire doctrine, the court seems predisposed to find that certain characteristics of the latches must have been " dictated by external factors such as particular business practices[,]' ... standard industry practices for constructing latches, or safety standards." ${ }^{234}$ If found, these features are filtered out largely based on the court's subjective interpretation of what is necessary, functional, efficient, or original. ${ }^{235}$

Potential for greater respect for visual works is afoot in the Sixth Circuit. In Winfield Collection, Ltd. v. Gemmy Industrial, Corp., the Sixth Circuit purported to apply the abstraction-filtration test in the context of a

${ }^{229}$ E.g., Stromback, 384 F.3d at 296-297; Murray Hill, 361 F.3d at 319-20.

${ }^{230}$ See Stromback, 384 F.3d at 296-97; Murray Hill, 361 F.3d at 319-320.

${ }^{231}$ See, e.g., Kohus v. Mariol, 328 F.3d 848, 857-58 (6th Cir. 2003) (drawing of a latch); Sturdza v. United Arab Emirates, 281 F.3d 1287, 1295-96 (D.C. Cir. 2002) (architectural designs); County Kids 'N City Slicks, Inc. v. Sheen, 77 F.3d 1280, 1284 (10th Cir. 1996) (wooden dolls).

${ }^{232}$ See Kohus, 328 F.3d at 856.

${ }^{233}$ See id.

${ }^{234}$ Id. (quoting Computer Mgmt. Assistance Co. v. Robert F. Castro, Inc., 220 F.3d 396, 401 (5th Cir. 2000)).

${ }^{235}$ Compare id. (many aspects of play-area latches filtered out as driven by industry practices, functionality, efficiency, or necessity), with Kellman v. Coca-Cola Co., 280 F. Supp. 2d 670, 676 (E.D. Mich. 2003) (aspects of foam headgear designed to look like a wing nut fastening device were not filtered out because court embraced the creators' original and creative conception of the work as a visual pun on the phrase "wing nuts" as nutty fanatics of the Detroit Red Wings hockey team). 
dispute involving a two-dimensional paper design for creating a "crashing witch" craft project that was compared to a competing three-dimensional "crashing witch" creation. ${ }^{236}$ The court found the works were purely aesthetic (as opposed to functional or utilitarian). ${ }^{237}$ In the analysis, the court considered the argument that most of the purported similarities of the two witch creations were merged with the idea of a crashing witch or were scènes à faire of witches in general: black clothing, curled boots, flowing cape, and a broom. ${ }^{238}$ But the court refused to end the analysis there. Instead, the court followed the reasoning of the Second Circuit in Mattel, Inc. v. Goldberger Doll Manufacturing Co. ${ }^{239}$ In Goldberger Doll, the Second Circuit recognized that works embodying common features are not without protecticn from direct copying. ${ }^{240}$ Even though in that case Mattel claimed a copyright for Barbie dolls that embody common doll features such as widely spaced eyes, upturned noses, and bow lips, the Second Circuit (as quoted by the Sixth Circuit) held that:

There are innumerable ways of making upturned noses, bow lips, and widely spaced eyes. Even if the record had shown that many dolls possess upturned noses, bow lips, and wide-spaced eyes, it would not follow that each such doll-assuming it was independently created and not copied from others-would not enjoy protection from copying. ${ }^{241}$

The finding that there are common features typical of the idea of a doll's face or scènes $\dot{a}$ faire of doll faces in general does not strike these features from the case under the merger doctrine or scènes à faire doctrine. ${ }^{242}$ Instead, the Sixth Circuit followed the Second Circuit in concluding that the court must compare the creative embodiment or arrangement of these common features in the original creator's work for evidence of direct copying. ${ }^{243}$ In Winfield, the court held that there was no similarity between

${ }^{236}$ See 147 Fed. App'x 547, 552-54 (6th Cir. 2005).

${ }^{237}$ Id. at 551.

${ }^{238} \mathrm{Id}$. at 554.

${ }^{239}$ Id. at 554-56 (citing Mattel, Inc. v. Goldberger Doll Mfg. Co., 365 F.3d 133 (2d Cir. 2004)).

${ }^{240} 365$ F.3d at 135.

${ }^{241}$ Winfield, 147 Fed. App'x at 554-55 (quoting Goldberger Doll, 365 F.3d at 135).

${ }^{242}$ See id. at 555 .

${ }^{243}$ See id. at $554-55$. 
the embodiment of the witch features in the one work compared to the other, thus summary judgment for the defendant still was affirmed by the Sixth Circuit. ${ }^{244}$ But the appreciation of visual works is on the rise in the circuit.

\section{Tenth Circuit}

The Tenth Circuit implements the reductionist method under the name of the abstraction-filtration-comparison test to determine whether one product is substantially similar to another. ${ }^{245}$ First, the court separates the ideas (and basic utilitarian functions), which are not protectable, from the particular expression of work. ${ }^{246}$ Then, the court filters out the unprotectable components of the product from the original expression. ${ }^{247}$ Finally, the court compares the remaining protected elements to determine if the two works are substantially similar. ${ }^{248}$

In Country Kids ' $N$ City Slicks, Inc., plaintiff was a wholesale doll manufacturer that sold wooden dolls similar in size and shape to traditional paper dolls. ${ }^{249}$ In mid-1993, plaintiff noticed defendants marketing and selling similar wooden paper dolls, and subsequently brought suit for copyright infringement. ${ }^{250}$ Defendants claimed that while their dolls employed the concept of plaintiff's dolls, their dolls had distinctly different features, such as the eyes, hair, and nose. ${ }^{251}$ Plaintiff argued that the wooden dolls were a form of expression of paper dolls, rather than an idea of a doll. ${ }^{252}$ The court stated, "to the extent that the idea and the particular expression cannot be separated, the work cannot be protected by copyright because 'protecting the 'expression' in such circumstances would confer a monopoly of the 'idea' upon the copyright owner.",253 Accordingly, the court affirmed the district court's characterization of wooden dolls as an

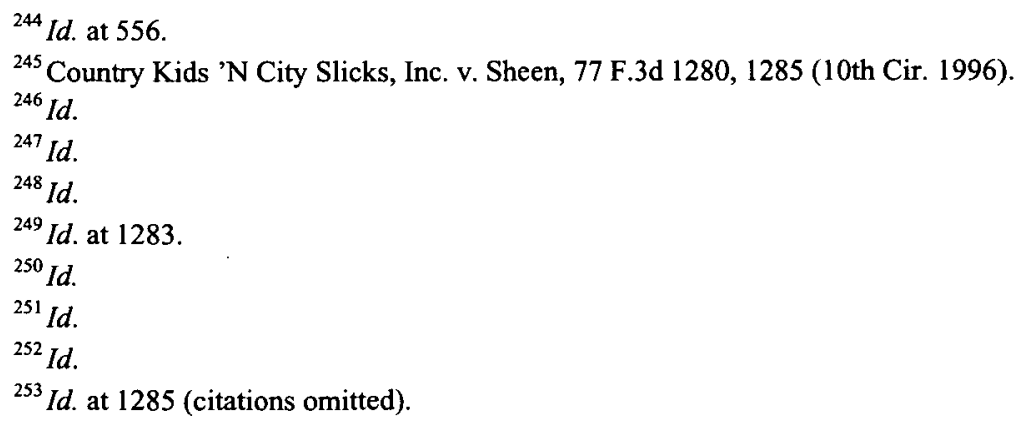


idea rather than a protected expression. ${ }^{254}$ In response to the plaintiff's argument that the features of the dolls are still copyrightable, the court stated: "[T] the extent that the shape and size of Plaintiff's dolls are not inherent in the idea of a wooden paper doll, they are typical paper doll features found in the public domain and therefore are not copyrightable."255 After abstracting the idea from the expression and filtering out the unprotectable elements of the dolls, the court then looked to determine whether the protectable portions of the original work that had been copied constituted a substantial part of the original work. ${ }^{256}$ In determining substantial similarity, the court opined that the traditional test is "whether the accused work is so similar to the plaintiff"s work that an ordinary reasonable person would conclude that the defendant unlawfully appropriated the plaintiff's protectable expression by taking material of substance and value.,"257

In Todd v. Montana Silversmiths, Inc., two artists who produce westernthemed jewelry squared off over competing barbed-wire bracelet and matching earrings creations. ${ }^{258}$ Even though the court stated that "one can imagine any number of original ways to rearrange silver wire, barbs, [and] end caps, ${ }^{, 259}$ the court eagerly applied the merger doctrine and took out the public domain elements of barbed-wire effects, hoop-style bracelets, and earrings. ${ }^{260}$ Plaintiff argued that the individual elements are not the focus of the originality tests, but rather the overall design (in plaintiff's words, the "creative gestalt") of the work. ${ }^{261}$ Citing Feist, plaintiff asserted that copyright protection attached to the particular way she formed, placed, balanced, and harmonized together the elements of her barbed wire styled jewelry. ${ }^{262}$ The court in its unhumble opinion did not think that plaintiff's combination of elements had any originality. ${ }^{263}$ The court held that plaintiff

${ }^{254} I d$. at 1286.

${ }^{255} I d$. at 1287 (citation omitted).

${ }^{256} \mathrm{Id}$.

${ }^{257}$ Id. at 1288 (quoting Atari, Inc. v. N. Am. Philips Consumer Elecs. Corp., 672 F.2d 607, 614 (7th Cir. 1982), superseded by rule in part, Fed. R. Civ. P. 52(a), as recognized in Scandia Down Corp. v. Euroquilt, Inc., 772 F.2d 1423, 1429 (7th Cir. 1985)).

${ }^{258} 379$ F. Supp. $2 d 1110,1111$ (D. Colo. 2005).

${ }^{259} \mathrm{Id}$. at 1113 .

${ }^{260}$ See id. at $1112-13$.

${ }^{261}$ See id. at 1112.

${ }^{262} I d$.

${ }^{263}$ See id. at 1113 . 
"arranged [the elements] in a way that by all objective measures still matches the elemental arrangement of barbed-wire."264 The court must have supposed that the artist simply walked out and found barbed wire hoops laying around in the shape of spurs, cowboy hats, and boots, and then just dusted them off and attached a post and clasp to some to distinguish the bracelets from the earrings. Thus, plaintiff could not preclude defendant from producing barbed wire jewelry in the exact same configurations of western symbols (boots, spurs, and cowboy hats). ${ }^{265}$

The ordinary observer test, as applied by the Tenth Circuit, does not require a work to be a virtual copy of a protected one. ${ }^{266}$ Nor does it turn on whether an ordinary observer would confuse the two works in their entirety. ${ }^{267}$ Rather, the test only answers whether a reasonable person would conclude that "[a] defendant unlawfully appropriated the plaintiff"s protectable expression by taking material of substance and value."268 Thanks to the merger and the scènes à faire doctrines, so much of the plaintiff's work can be stripped away that it is easy, as a matter of law, to imagine that no other work could be substantially similar to the plaintiff's, regardless of whether another started out to copy it or not.

\section{Eleventh Circuit}

The Eleventh Circuit's application of the merger and scènes à faire doctrines in cases involving literary works is unremarkable. ${ }^{269}$ It is its approach to the two doctrines in cases involving visual works that earns it its placement among the circuits favoring an expansive application of the doctrines. In Leigh $v$. Warner Brothers, Inc. the court applied the merger and scènes à faire doctrines in its analysis of photographer Jack Leigh's photographs of the Bird Girl statue in Bonaventure Cemetery in Savannah, Georgia that were allegedly copied for use in the promotion of the film, Midnight in the Garden of Good and Evil. ${ }^{270}$ The court pointed out several

${ }^{264} I d$.

${ }^{265}$ See id. at $1113-14$.

${ }^{266}$ See Country Kids 'N City Slicks, Inc. v. Sheen, 77 F.3d 1280, 1288 (10th Cir. 1996).

${ }^{267}$ See id.

${ }^{268}$ Id. (quoting Atari, Inc. v. N. Am. Philips Consumer Elecs. Corp., 672 F.2d 607, 614 (7th Cir. 1982), superseded by rule in part, Fed. R. Civ. P. 52(a), as recognized in Scandia Down Corp. v. Euroquilt, Inc., 772 F.2d 1423, 1429 (7th Cir. 1985)).

${ }^{269}$ See generally Palmer v. Braun, 287 F.3d 1325 (11th Cir. 2002); Herzog v. Castle Rock Entm't., 193 F.3d 1241 (11 th Cir. 1999).

${ }^{270}$ See 212 F.3d 1210, 1213-15 (11th Cir. 2000). 
obvious restrictions on the protectable content of Leigh's work, including the subject matter of the work (the statue itself) and the setting of the photograph in Bonaventure Cemetery as the appearance of the statute and the cemetery are facts and not copyrightable. ${ }^{271}$ Further, the court stated that any connotations surrounding the statue as associated with the mood, themes of the novel, or its setting are ideas and thus unprotectable even though these associations may owe their origin to Leigh's original use of his photograph to illustrate the cover of the novel, Midnight in the Garden of Good and Evil. ${ }^{272}$

The Eleventh Circuit recognized the lighting, shading, timing, angle, and film choices as protected elements of Leigh's work. ${ }^{273}$ Leigh stressed that the court should also look at the combined effect of these separate elements as creating an eerie mood and suggesting the spirituality of the scene. ${ }^{274}$ The court disagreed, finding that "eerie moods" and "spiritual moods" were scènes à faire of cemeteries. ${ }^{275}$ The court did not stop to dwell on the incongruity of the finding that Leigh had copied a stock image of an eerie mood or a spiritual mood when he photographed the Bird Girl statue. $^{276}$ The court was reluctant to allow the comparison of the total concept and especially the feeling evoked by the complete work for the same reason that Leigh was demanding such an evaluation: that the viewer would be attracted by the mood evoked by the photograph and would be unable to untangle the mood effects of the subject matter itself from the creative additions of Leigh. ${ }^{277}$ It approved of the lower court's dissection and evaluation of the similarities and dissimilarities of the Leigh photograph and the images of the Bird Girl that appear in the film and the court's grant of summary judgment to defendants on the film footage, but did not approve of the lower court's grant of summary judgment on the promotional still photographs created by defendants. ${ }^{278}$ The court found that

${ }^{271}$ Id. at $1214-15$.

${ }^{272}$ See id. at 1214; see also Original Appalachian Artworks, Inc. v. Toy Loft, Inc., 684 F.2d $821,829 \mathrm{n} .11$ (11th Cir. 1982) (idea of soft sculpture human-figure doll is not copyrightable).

${ }^{273}$ Leigh, 212 F.3d at 1215.

${ }^{274}$ Id.

${ }^{275}$ See id.

${ }^{276}$ See id.

${ }^{277}$ See id.

${ }^{278}$ See id. at 1215-16. 
these photographs might be found by an average viewer to be substantially similar to Leigh's photographs, and thus reversed and remanded the case. ${ }^{279}$

\section{Federal Circuit}

The Federal Circuit is neutral on the application of the merger and scènes $\dot{a}$ faire doctrines because in a copyright claim, the Federal Circuit applies copyright law as interpreted by the regional circuit wherein the facts of the case arose. ${ }^{280}$ Thus, the Federal Circuit in Amini Innovation Corp. v. Anthony California, Inc. was happy to apply the Ninth Circuit's interpretation and application of the merger and scènes à faire doctrines as reflected in its substantial similarity tests. ${ }^{281}$ The court reversed the trial court for having taken on the intrinsic similarity analysis of carved ornamental designs on woodwork without acknowledging the fact intensive nature of the analysis which made the case inappropriate for summary judgment on the intrinsic analysis part of the test. ${ }^{282}$

The United States Court of Federal Claims produced a remarkably expansive opinion applying the merger and scènes $\dot{a}$ faire doctrines to a work depicting a heart-shaped picture of Earth. ${ }^{283}$ The jurisdiction of the court was triggered because the artist, Meade, accused the United States Postal Service of copying his heart-shaped Earth design on a postage stamp. $^{284}$ The court held that Meade's work was uncopyrightable under the merger doctrine because the entire depiction was an idea not an expression. $^{285}$ Furthermore, any trivial variations added by the creative, original input of the artist, such as the color, placement, and appearance of the continents on the Earth picture, were dismissed as scènes à faire elements dictated by the requirements of any depiction of the scene. ${ }^{286}$ In what might be described as stunning incongruity, the court plainly stated that "[w] $[\mathrm{wile}$ a heart-shaped picture of earth certainly can be considered an

${ }^{279}$ See id. at 1216 .

${ }^{280}$ Amini Innovation Corp. v. Anthony Cal., Inc., 439 F.3d 1365, 1368 (Fed. Cir. 2006); Atari Games Corp. v. Nintendo of Am., Inc., 897 F.2d 1572, 1575 (Fed. Cir. 1990).

${ }^{281}$ See 439 F.3d at 1368.

${ }^{282}$ See id. at 1370.

${ }^{283}$ See Meade v. United States, 27 Fed. Cl. 367, 369-72 (1992), affd, 5 F.3d 1503 (Fed. Cir. 1993) (unpublished table decision).

${ }^{284}$ Meade, 27 Fed. Cl. at 370-72.

${ }^{285}$ Id. at 371 .

${ }^{286}$ See id. at $372-73$. 
expression of a larger idea, such a picture is itself capable of being expressed in myriad ways, each varying depending on the selection and arrangement of continents, colors, words, and other details." 287 Ignoring the maxim cited above, that when myriad variations of a scene are possible, a myriad of protectable copyrights can coexist, ${ }^{288}$ the court granted summary judgment for the defendant. ${ }^{289}$

\section{B. Circuits Restricting the Application of the Merger and Scènes à Faire Doctrines in the Visual Media Context}

The important difference between the circuits presented in this section and the circuits presented above is not in the comparison test they use, but rather in whether or not they have a mature and circumscribed understanding of the merger and scènes à faire doctrines in the context of visual works. The particular version of the substantial similarity test used is not nearly as important. A circuit that revels in physical dissection of works may still have a mature understanding of the limitations of the merger and scènes à faire doctrines with respect to visual works and will avoid the most blatant forms of chopping and dissection. A circuit that professes to preserve the total concept and feel of the work for an intrinsic similarity evaluation may still have an expansive view of the applicability of the merger and scènes a faire doctrines to visual works and will wind up taking the case away from the finder of fact at the extrinsic similarity stage, or through instructions given as part of a more discerning observer analysis, or after an intrinsic comparison because the court has determined that the only features copied are barred by merger or scènes à faire under an expansive reading of the two doctrines. Therefore, a mature understanding of the limits or nonapplicability of the two doctrines is essential to protecting the full potential of visual media from copying.

\section{Second Circuit}

The Second Circuit is as much to blame for the application of the merger and scènes à faire doctrines to visual works as it is for showing, of late, a great deal of restraint in the application of these doctrines in the comparison of visual works. It was the Second Circuit in Nichols that laid

\footnotetext{
${ }^{287} I d$. at 372.

${ }^{288}$ See Dymow v. Bolton, 11 F.2d 690, 691 (2d Cir. 1926).

${ }^{289}$ Meade, 27 Fed. Cl. at 374.
} 
out the philosophical justification for both the merger and the scènes a faire doctrines and the abstraction test. ${ }^{290}$ It was also the Second Circuit in Altai that added the filtration and comparison parts to the abstraction test in the context of computer programs, and in so doing, brought the scènes à faire doctrine to computerized visual works. ${ }^{291}$

The lower courts of the circuit, particularly the Southern District of New York, have produced famously expansive opinions on the merger and scènes $\dot{a}$ faire doctrines. ${ }^{292}$ The Second Circuit has happily applied the merger and scènes à faire doctrines to lifelike toys, such as dolls in humanoid form, and just as happily preserved the same types of dolls from the two doctrines when it suited it to do so. ${ }^{293}$

${ }^{290}$ See Nichols v. Universal Pictures Corp., 45 F.2d 119, 121 (2d Cir. 1930).

${ }^{291}$ See Computer Assocs. Int'l, Inc. v. Altai, Inc., 982 F.2d 693, 707-10 (2d Cir. 1992); see also Atari, Inc. v. N. Am. Philips Consumer Elecs. Corp., 672 F.2d 607, 617 (7th Cir. 1982), superseded by rule in part, Fed. R. Civ. P. 52(a), as recognized in Scandia Down Corp. v. Euroquilt, Inc., 772 F.2d 1423, 1429 (7th Cir. 1985) (maze framework of PAC-MAN is a standard game device and thus not copyrightable under doctrine of scènes à faire; only specific characters used in the game are protectable).

${ }^{292}$ See, e.g., Earth Flag Ltd. v. Alamo Flag Co., 153 F. Supp. 2d 349, 353-58 (S.D.N.Y. 2001) (flag depicting photograph of the Earth has no original components that entitled it to copyright protection); Past Pluto Prods. Corp. v. Dana, 627 F. Supp. 1435, 1440-45 (S.D.N.Y. 1986) (no originality in foam hat designed to resemble the Statue of Liberty's crown).

${ }^{293}$ See Mattel, Inc. v. Azrak-Hamway Int'l, Inc., 724 F.2d 357, 360 (2d Cir. 1983) ("Though the dolls' bodies are very similar, nearly all of the similarity can be attributed to the fact that both are artist's renderings of the same unprotectable idea-a superhuman muscleman crouching in ... a traditional fighting pose."); Eden Toys, Inc. v. Marshall Field \& Co., 675 F.2d 498, 500-01 (2d Cir. 1982) (finding no infringement where both plaintiff and defendant produced stuffed snowmen of the same size with traditional snowman features); Durham Indus., Inc. v. Tomy Corp., 630 F.2d 905, 915-17 (2d Cir. 1980) (finding no infringement although dolls were mechanically identical and structurally similar, both were made of plastic and between three and four inches tall and there was similarity as to standard doll features; mechanical aspects of dolls were not copyrightable and "all dolls attempting to express the same idea will of necessity display at least some similarity"); Ideal Toy Corp. v. Fab-Lu Ltd., 360 F.2d 1021, 1022-23 (2d Cir. 1966) (many features of doll faces are standard and stereotypical); Uneeda Doll Co. v. P \& M Doll Co., 353 F.2d 788, 789 (2d Cir. 1965) (per curiam) (idea of doll in a display box with its arm around a red and white striped pole is not copyrightable); Ideal Toy Corp. v. Kenner Prods. Div. of Gen. Mills Fun Group, Inc., 443 F. Supp. 291, 304 (S.D.N.Y. 1977) ("The defendants have no more right to a monopoly in the theme of a black-robed, helmeted, evil figure in outer-space conflict with a humanoid and a smaller non-humanoid robot than Shakespeare would have had in the theme of a 'riotous knight who kept wassail to the discomfort of the household' and who had conflicts with 'a foppish steward who became amorous of his mistress." (citation omitted)); see also Mattel, Inc. v. Goldberger Doll Mfg. Co., 365 F.3d 133, 135 (2d Cir. 2004) ("There are innumerable ways of making upturned noses, bow lips, and widely spaced eyes."). 
In Mattel v. Goldberger Doll Manufacturing Co., the court recognized that there are an unlimited number of ways of combining standard features of dolls depicting youthful female faces. ${ }^{294}$ This means that any doll creator can use the same stock of features (bow lips, pert noses, large, widespread eyes) without limitation, but the doll creator cannot copy the creative and original arrangement of those features expressed in the work of another author. Barbie is Barbie because Mattel put together a winning combination of stock doll features in an attractive and original way. ${ }^{295}$ Mattel has no monopoly on pert noses, bow lips, or any other typical facial figures of dolls, but it does have a monopoly on its original combination of these stock features, which add up to the instantly recognizable face of a Barbie doll. ${ }^{296} \mathrm{~A}$ competitor must make its own combination because it cannot copy Mattel's. ${ }^{297}$

The merger doctrine does not apply to Mattel's doll image because doll creators are not limited in how to depict the face of a youthful female; the scènes à faire doctrine does not apply because there are unlimited combinations of stock features of dolls all of which may be separately copyrighted. ${ }^{298}$ In like manner, the Second Circuit recently held that the merger and scènes à faire doctrines do not apply to original combinations of common, unprotected elements of an on-line grocery shopping site ${ }^{299}$ or to original selections and arrangements of common articles in jewelry designs. ${ }^{300}$

The present law of the Second Circuit preserves works whose features are alleged to be subject to the merger and scènes à faire doctrines from exclusion in the subjective, intrinsic similarity portion of the substantial similarity evaluation. ${ }^{301}$ More often than not, this will allow the finder of fact the opportunity to consider the substantiality of the similarity between the total work of the plaintiff compared to the total work of the

\footnotetext{
${ }^{294}$ See Goldberger Doll, 365 F.3d at 135.

${ }^{295}$ See id.

${ }^{296}$ Id. at 136.

${ }^{297}$ Id.

${ }^{298}$ See id. at 135.

${ }^{299}$ See MyWebGrocer, LLC v. Hometown Info., Inc., 375 F.3d 190, 193-94 (2d Cir. 2004).

${ }^{300}$ See Yurman Design, Inc. v. PAJ, Inc., 262 F.3d 101, 111-12 (2d Cir. 2001).

${ }^{301}$ See Goldberger Doll, 365 F.3d at 136-37; Tufenkian Imp./Exp. Ventures, Inc. v. Einstein Moomjy, Inc., 338 F.3d 127, 133-34 (2d Cir. 2003); Boisson v. Banian, Ltd., 273 F.3d 262, 268
} 72 (2d Cir. 2001). 
defendant. ${ }^{302}$ The Second Circuit's rationale for employing a "total concept and feel" test is "[that the test] functions as a reminder that, while the infringement analysis must begin by dissecting the copyrighted work into its component parts in order to clarify precisely what is not original, infringement analysis is not simply a matter of ascertaining similarity between components viewed in isolation." 303

For example, in Boisson, the plaintiff claimed that the defendant copied two of her registered quilt designs. ${ }^{304}$ The court first looked to whether the plaintiff owned a valid copyright and determined that she did. ${ }^{305} \mathrm{Next}$, the court concluded that the defendant actually did copy plaintiff's work. ${ }^{306}$ But because pure copying does not establish infringement, the plaintiffs still must show "substantial similarity' between defendants' quilts and the protectable elements of their own quilts." $" 307$ Although colors in general and the letters of the alphabet in particular are part of the public domain and the idea of using letters of the alphabet on a quilt was an unprotectable idea, the court held that the layout of the alphabet on plaintiff's quilt (the arrangement, shape, combination of colors, and overall design of how the letters would appear on the quilt) was protectable because it was an independent creation. ${ }^{308}$

Having found that plaintiff's quilts were copyrightable and that the defendant actually copied some of the elements of the quilt, the court went on to determine if the quilts were substantially similar. ${ }^{309}$ The court first looked to whether "the ordinary observer ... would be disposed to overlook [the disparities], and regard their aesthetic appeal as the same." ${ }^{310}$ In applying this test, the court applied a "total concept and feel" standard. ${ }^{311}$ Therefore, the court compared the defendant's and the plaintiff's quilts on

${ }^{302}$ See, e.g., Goldberger Doll, 365 F.3d at 135; Tufenkian, 338 F.3d at 133-34; Boisson, 273 F.3d at $272-73$.

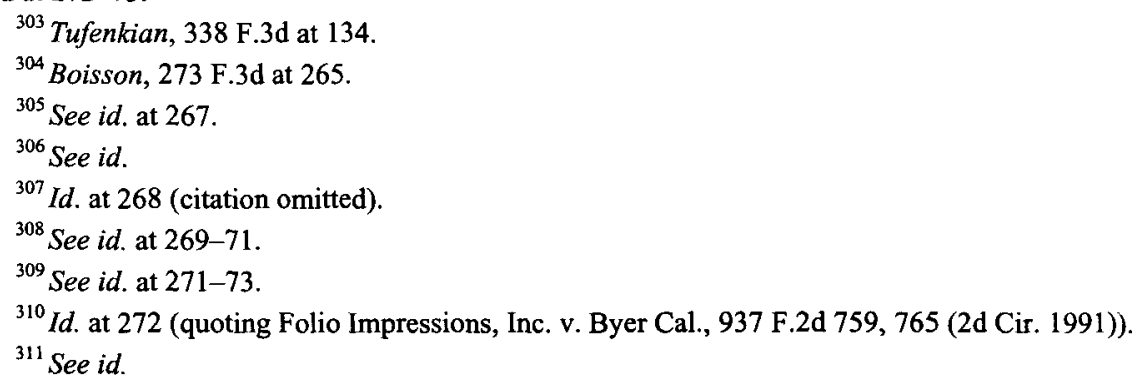


the basis of arrangement and shapes of the letters, colors chosen, quilting patterns, and particular placement of icons. ${ }^{312}$

The Second Circuit devised a solution to a problem raised by the facts of the case: Plaintiff Boisson admitted that some aspects of the quilts (the use of alphabet letters in large blocks, on a quilt) were copied from other sources. ${ }^{313}$ Because some of the quilt was not original and, therefore, not protectable, the court then applied a "more discerning [observer] test" which is required when a plaintiff's work is not wholly original but rather incorporates elements from the public domain. ${ }^{314}$ The test is not used when there is no proof, admission, or concession in the case that plaintiff copied certain other works and incorporated them into the work in question. ${ }^{315}$ For the "more discerning observer" test, the ordinary observer must view the work as a whole but with a more critical eye; it must discern substantial similarity while taking into account the court's instructions that certain parts of the plaintiff's work are not original and not to be considered. ${ }^{316}$ The observer must find substantial similarity between only those elements that are copyrightable. ${ }^{317}$ In Boisson, because the concept of using letters from the alphabet in large blocks on a quilt was taken from the public domain, the court determined that it had to apply a "more discerning ordinary observer test." 318

The apparent difference between the dissection-filtration approach and the "more discerning observer" approach is that in the latter the observer still is to compare the works as a whole. ${ }^{319}$ The observer must mentally note that if the only similarity noted is as to the unoriginal components instructed to the observer by the court (e.g., in Boisson, if the only similarity noted was that the two quilts each featured letters of the alphabet in large blocks), then the observer is to return a finding of no substantial

${ }^{312} I d$. at 273.

${ }^{313} \mathrm{Id}$. at 269.

${ }^{314}$ See id. at 272; see also Key Publ'ns, Inc. v. Chinatown Today Publ'g Enters., Inc., 945 F.2d 509, 514 (2d Cir. 1991).

${ }^{315}$ Boisson, 273 F.3d at 272; see also Key Publ'ns, Inc., 945 F.2d at 514.

${ }^{316}$ See Boisson, 273 F.3d at 272.

${ }^{317}$ See id.

${ }^{318} I d$.

${ }^{319} I d$. ("[W]e have nevertheless always recognized that the [more discerning] test is guided by comparing the 'total concept and feel' of the contested works." (citing Knitwaves, Inc. v. Lollytogs Ltd., 71 F.3d 996, 1003 (2d Cir. 1995))). 
similarity. ${ }^{320}$ Under the dissection-filtration approach, the courts give the impression that the observer never is to see the unoriginal parts; in the case of a visual work, they might very well be erased, masked, cut, or whited out of the depiction. This approach makes it extremely difficult if not impossible to evaluate the concept and feel of the piece, let alone the total concept, look, and feel.

The important difference between the Second Circuit and other courts (particularly the circuits presented above) is not in the comparison test it uses but rather in its thoughtful and circumscribed understanding of the merger and scènes à faire doctrines in the context of visual works. The test used is not nearly as important. A circuit that revels in physical dissection of works may still have an understanding of the limitations of the merger and scènes à faire doctrines with respect to visual works and will avoid the most blatant forms of chopping and dissection. A circuit that professes to preserve the total concept and feel of the work for an intrinsic similarity evaluation may still have an expansive view of the applicability of the merger and scènes à faire doctrines to visual works and will wind up taking the case away from the finder of fact at the extrinsic similarity stage, or through instructions given as part of a "more discerning observer" analysis, or after an intrinsic comparison because the court has determined that the only features copied are barred by merger or scènes à faire under an expansive reading of the two doctrines. Therefore, an understanding of the limits or nonapplicability of the two doctrines is essential to protecting the full potential of visual media from copying.

In Boisson, the use of letters and the placement of letters in large blocks were not original but the arrangement, shape, color, and design of the letters used and all of the non-alphabetical design elements were original. ${ }^{321}$ The court did not filter out the alphabet letters from consideration because to do so would deny the plaintiff recognition and protection for the original and creative arrangement, shape, color, and design of the letters used. After a comparison of the several quilts at issue in the case, the Second Circuit

${ }^{320} \mathrm{Id}$,

${ }^{321}$ Id. at 273-74. See also Tufenkian Imp./Exp. Ventures, Inc. v. Einstein Moomjy, Inc., 338 F.3d 127, 129-30, 134-35 (2d Cir. 2003) (stating that certain elements of plaintiff's rugs admittedly were copied from public domain sources, but the arrangement, combination, and manipulation of those elements were original; the observer was to consider the rugs as a whole bearing in mind that substantial similarity cannot be attributed solely to a common, non-original element). 
concluded that some of the defendants' quilts were substantially similar to plaintiff's and some were not. ${ }^{322}$

\section{Third Circuit}

Franklin Mint Corp. v. National Wildlife Art Exchange, Inc. is a landmark Third Circuit opinion on the idea-expression dichotomy. ${ }^{323}$ The court considered the situation of a wildlife artist who transferred the copyright to a painting of a male and female cardinal, and later painted another work embodying the same subject matter. ${ }^{324}$ The copyright owner of the first painting alleged infringement. ${ }^{325}$ The court traveled the path of the law, finding that although the subject matter or theme of the works was an unprotectable idea, the embodiment of the idea of a naturalistic painting of two cardinals in the two works was separately protectable. ${ }^{326}$ Far from denying that the first work did not have copyright protection because it featured an accurate and realistic rendition of factual subject matter from the real world (the nature and appearance of cardinals), the court focused instead on whether the second work was substantially similar to the first work. $^{327}$ The court never discussed the merger doctrine or scènes à faire doctrine even though the opportunity was staring it in the face-the idea of an actual cardinal might be held to merge with every realistic depiction of the bird, thus rendering every painting of the bird to be uncopyrightable. On the other hand, the scènes à faire doctrine might have been held to dispel the plaintiff's claim because any realistic depiction of an actual bird might very well have been held to be the kind of stock image or natural theme that must be done in order to depict the bird, and thus be held uncopyrightable. $^{328}$ Regardiless of the two doctrines, the Third Circuit

${ }^{322}$ Boisson, 273 F.3d at 274-75.

${ }^{323} 575$ F.2d 62, 67 (3d Cir. 1978).

${ }^{324} \mathrm{Id}$. at $63-64$.

${ }^{325} \mathrm{Id}$. at 63 .

${ }^{326} I d$. at $64-65$.

${ }^{327} \mathrm{Id}$. at $65-66$.

${ }^{328}$ Cf. Universal Athletic Sales Co. v. Salkeld, 511 F.2d 904, 908-09 (3d Cir. 1975). The court passed up the opportunity to apply the merger doctrine or scènes à faire doctrine in an earlier case involving charts designed to illustrate weight-lifting techniques. See id. Instead of stripping the first chart of its design elements because they are merged with concepts relating to weight-lifting or embody a scène a faire relating the use of weight machines, the court simply evaluated the two works side-by-side for comparison of similarity. See id. The court stated: "[W]ith respect to commercial documents ... the similarity probably must be more extensive than 
approved of the submission of the two works to the finder of fact for analysis of substantial similarity, and on appeal the court carefully weighed the two works side by side and found an absence of similarity in several notable features of the two works, supporting the findings below. ${ }^{329}$ The Third Circuit concluded that it is perfectly acceptable for an artist to create a "variation on a theme" of an earlier work without copying it even if the two works do have obvious similarities because they depict the same subject matter and are by the hand of the same artist. ${ }^{330}$

Parts of Franklin Mint Corp. are still evident in Third Circuit jurisprudence. In Southco, Inc. v. Kanebridge Corp. ${ }^{331}$ then Circuit Judge Alito, writing for the Third Circuit sitting en banc, embraced the doctrine of originality as established in Feist ${ }^{32}$ and Sarony. ${ }^{33}$ The Third Circuit endorsed the doctrine that a mechanical process such as photography that captures a slice of reality nonetheless reveals artistic creativity and originality. ${ }^{334}$ The court recognized that the subject matter of photography may be the real world objects and places (unprotectable facts) but the artist captures and creates an original embodiment in the form of an original work of photographic art (protectable expression). ${ }^{335}$

The Third Circuit determined that a screw fastener manufacturer had not achieved the requisite level of originality in the mechanical application of a numbering system for its products. ${ }^{336}$ The assignment of numbers was based on a scheme or process invented by Southco, but like other processes and methods of operation, it was held to be uncopyrightable under 17 U.S.C. $\S 102(b){ }^{337}$

Circuit Judge Roth, in dissent, reminded the court that where "the same idea can be expressed in a plurality of totally different manners, a plurality

in the case of more artistic works in order to justify a finding of substantial similarity." Id. at 908 (quoting 1 M. NIMMER, NIMMER ON COPYRIGHT $§ 143.2$ (1973)).

${ }^{329}$ See Franklin Mint Corp., 575 F.2d at 66.

${ }^{330}$ See id.

331390 F.3d 276, 281-84 (3d Cir. 2004) (en banc), cert. denied, 126 S. Ct. 336 (2005).

${ }^{332}$ Id. at 281 (discussing Feist Publ'ns, Inc. v. Rural Tel. Serv. Co., 499 U.S. 340, 358-63 (1991)).

${ }^{333} I d$. at 283-84 (discussing Burrow-Giles Lithographic Co. v. Sarony, 111 U.S. 53, 58-59 (1884)).

\footnotetext{
${ }^{334}$ See id. at 284.

${ }^{335}$ See id.

${ }^{336} \mathrm{Id}$. at 281 .

${ }^{337}$ Id. at $284-85$.
} 
of copyrights may result." ${ }^{338}$ Later in the dissent, Judge Roth stated: "While facts may not be copyrighted, original selections and arrangements of facts are entitled to protection. Thus, with respect to the selection and arrangement of non-copyrightable facts, 'it is almost inevitable that the original contributions of the compilers will consist of ideas." ${ }^{339}$ In these circumstances, Circuit Judge Roth points out, the merger doctrine should not prevent the recognition of copyright for original combinations and arrangements of unprotectable elements. ${ }^{340}$

Although the majority and the dissent in Southco seemed to be walking the same path for a great distance, the ultimate disagreement on the application of Feist's originality principles reveals the trouble courts have in recognizing the originality and copyrightability of original creations that incorporate or compile subject matter that is arguably uncopyrightable as ideas, processes and procedures, or stock themes and images. ${ }^{341}$ The confusion became most obvious in other circuits in the case of copyrightability of computer programs. The Third Circuit was one of the pioneers of the application of originality principles to this troublesome area, and like some pioneers, it had trouble staying on course. ${ }^{342}$

In Whelan the Third Circuit held that the non-literal structure of a computer program represented expression, rather than an idea, and was entitled to copyright protection. ${ }^{343}$ Non-literal is a term used in reference to the so-called "literal" parts of programs - the source code and object

${ }^{338}$ Id. at 293 n. 11 (Roth, J., dissenting) (quoting Apple Computer, Inc. v. Franklin Computer Corp., 714 F.2d 1240, 1253 (3d Cir. 1983)).

${ }^{339}$ Id. at 297 (quoting CCC Info. Servs., Inc. v. MacLean Hunter Mkt. Reports, Inc., 44 F.3d 61,70 (2d Cir. 1994)) (citations omitted) (emphasis in original).

${ }^{340}$ Id. at 293 n.11, 297.

${ }^{341}$ Id. at $281-82,297$.

${ }^{342}$ See generally, Whelan Assocs., Inc. v. Jaslow Dental Lab., Inc., 797 F.2d 1222 (3d Cir. 1986).

${ }^{343} I d$. at 1239 . Whelan has been roundly criticized for its ultimate interpretation of the ideaexpression dichotomy - that everything nonessential to a computer program's function may be interpreted as "expression" and not the "idea" of the program. See, e.g., Gates Rubber Co. v. Bando Chem. Indus., Ltd., 9 F.3d 823, 840, 844 (10th Cir. 1993); Sega Enters. Ltd. v. Accolade, Inc., 977 F.2d 1510, 1525 (9th Cir. 1992); Computer Assocs. Int'l, Inc. v. Altai, Inc., 982 F.2d 693, 705 (2d Cir. 1992); Plains Cotton Coop. Ass'n v. Goodpasture Computer Serv., Inc., 807 F.2d 1256, 1262 (5th Cir. 1987). I cite Whelan for its historical role in developing the abstractionfiltration test as a method of separating unprotectable elements from protectable elements in copyrightable works, not as a precedent on proper interpretation of the idea-expression dichotomy or the abstraction-filtration test. 
code-that is coded by a programmer and thus is verbal in nature (alphanumeric) in that it contains arabic numbers and sometimes letters and actual words (although object code has heretofore been limited to a sequence of 1's and 0's functioning as "on" and "off" commands to the machine). ${ }^{344}$ The non-literal parts are the design elements or applications (the opinion discussed them as algorithms, subroutines, and modules) which the programmer wished to achieve when she puts together the code. ${ }^{345}$ This allows comparison of the audiovisual output and other user applications of the program. ${ }^{346}$

The Third Circuit recognized that the scènes à faire doctrine or merger doctrine might come into play with computer programs as literary works. ${ }^{347}$ The court has limited the doctrine in two important respects. First, the doctrine is to be applied from the perspective of the creator of the work, not the plagiarist. ${ }^{348}$ In other words, if the creator of the computer program was limited in her design choices by the requirements or limitations of the programming language (there are a limited number of ways to get a task accomplished using the programming language), or the machinery (there are a limited number of variations that will run properly on the computer hardware the program is being designed to run on), or by standard operating procedures for computer programming (sound programming policies dictate certain programming choices), then these limitations may affect how original the choices were that were made by the programmer. ${ }^{349}$ Choices dictated by the language, the machinery, or by standard procedures are not original to the programmer and thus not copyrightable by the programmer. ${ }^{350}$ The difference is that only choices dictated by the constraints of the programming language or the machinery or standard procedures would be subject to attack by the plagiarist who would bear the burden of proving that elements were not original; the doctrine does not reward the choice of the plagiarist to copy the original program under a

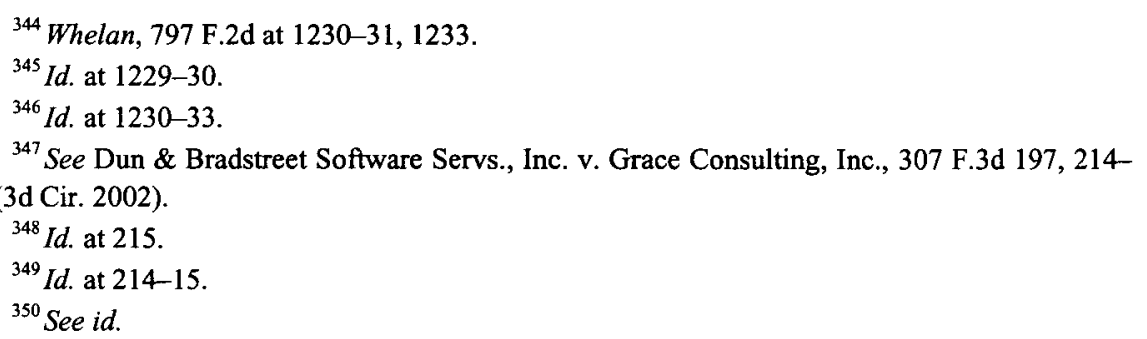


belief that most of the program must have been dictated by the programming language or the machinery or standard procedures. ${ }^{351}$

The Third Circuit's approach to merger is restrictive, particularly with regard to visual works. In Kay Berry, Inc. v. Taylor Gifts, Inc., the court evaluated allegations of merged idea and expression in the context of a cement-cast outdoor garden sculpture. ${ }^{352}$ The Kay Berry, Inc. sculptures were designed to look like rocks or stones but included a flat area with an inscription molded onto the sculpture. ${ }^{353}$ The sculpture at issue in the litigation bore a public domain poem, but the lettering and arrangement of the words showed design choices regarding the font and grouping of the lines. $^{354}$ In Kay Berry, a competitor, Taylor, came out with a similar sculpture in the same size, rectangular shape, stone-like appearance, with the same poem arranged in the same style of font and word grouping. ${ }^{355}$ To defend its version of the sculpture, Taylor claimed that Kay Berry's sculpture was uncopyrightable under the merger doctrine. ${ }^{356}$

The Third Circuit stated: "Merger is rare ... and is generally found in works with a utilitarian function. This Court has never found an instance in which a completely aesthetic expression merged into an idea." 357 The court further stated that "[a] sculptural work's creativity derives from the combination of texture, color, size, and shape, as well as the particular verse inscribed and the way the verse is presented." 358

The court did not strip the sculpture of its characteristics under a theory of merger or scènes à faire. Instead the court stated:

It means nothing that these elements may not be individually entitled to protection; "all creative works draw on the common wellspring that is the public domain. In

${ }^{351}$ See id. at $215-16$.

${ }^{352}$ See 421 F.3d 199, 202 (3d Cir. 2005).

${ }^{353} \mathrm{Id}$.

${ }^{354}$ Id.

${ }^{355} \mathrm{Id}$.

${ }^{356}$ See id. at 207-08. The allegation easily could have been made under the scènes à faire doctrine in that representations of natural objects are often held to be the kind of stock images that are alleged to be uncopyrightable under the doctrine. See, e.g., Satava v. Lowry, 323 F.3d 805, 810 n.3 (9th Cir. 2003).

${ }^{357}$ Kay Berry, 421 F.3d at 209. (citing Educ. Testing Servs. v. Katzman, 793 F.2d 533, 539 (3d Cir. 1986); Brown Instrument Co. v. Warner, 161 F.2d 910 (D.C. Cir. 1947); M.M. Bus. Forms Corp. v. Uarco, Inc. 472 F.2d 1137 (6th Cir. 1973)).

${ }^{358}$ Kay Berry, 421 F.3d at 207. 
this pool are not only elemental 'raw materials,' like colors, letters, descriptive facts, and the catalogue of standard geometric forms, but also earlier works of art that, due to the passage of time or for other reasons, are no longer copyright protected." $" 359$

The court continued: "When an author combines these elements and adds his or her own imaginative spark, creation occurs, and the author is entitled to protection for the result." ${ }^{\text {630 }}$ The court directly analogized the situation with Kay Berry's sculpture to two situations: that of a magazine cover design and to three-dimensional costume nose masks. ${ }^{361}$ With regard to the former, the Third Circuit stated that "although no element of [a] magazine cover-ordinary lines, typefaces, and colors-is entitled to copyright protection, the distinctive arrangement is entitled to protection as a graphic work." ${ }^{362}$ With regard to the latter, the court found that sculptural renderings of animal noses were original, copyrightable creations even though they embodied realistic elements of actual living creatures and anyone setting out to make a realistic sculpture of an animal nose would be bound to turn to the same source material: actual animals. ${ }^{363}$ The court stated:

By holding that Masquerade's nose masks are copyrightable, we do not intimate that [Masquerade] has the exclusive right to make nose masks representing pig, elephant and parrot noses. On remand, it will be Masquerade's burden to show that Unique's nose masks incorporate copies, in the copyright law sense, of Masquerade's sculptures, rather than sculptures that derive their similarity to Masquerade's sculptures merely from the commonality of the animal subjects both represent. ${ }^{364}$

${ }^{359}$ Id. (citing Tufenkian Imp./Exp. Ventures, Inc. v. Einstein Moomjy, Inc., 338 F.3d 127, 132 (2d Cir. 2003)).

${ }^{360}$ Id. (citing Feist Publ'ns, Inc. v. Rural Tel. Serv. Co., 499 U.S. 340, 345 (1991)).

${ }^{361} I d$. at $207,209$.

${ }^{362}$ Id. at 207 (citing Reader's Digest Ass'n, Inc. v. Conservative Digest, Inc., 821 F.2d 800, 806 (D.C. Cir. 1987)).

${ }^{363}$ See id. at 209 (discussing Masquerade Novelty, Inc. v. Unique Indus., Inc. 912 F.2d 663, 666, 671-72 (3d Cir. 1990)).

${ }^{364}$ Id. (citing Masquerade Novelty, 912 F.2d at 671-72). 
The difference is that the court will not strip the sculptures down to nothing by subtracting out individual parts or characteristics embodied in the works that relate to the idea of real objects or creatures, and subsequently take the case away from the finder of fact on summary judgment or judgment as a matter of law or directed verdict because the majority of parts or characteristics embodied in the work do relate to real world objects. ${ }^{365}$ Instead, the Third Circuit will allow the plaintiff to prove and the finder of fact to consider whether, "as a whole," 366 the unique expression of the first creator's combination and arrangement of the elements has been copied or whether the similarities between the works are solely attributable to the two works' unavoidable expression of the noncopyrightable and non-original innate characteristics of real world objects. ${ }^{367}$

\section{Fourth Circuit}

The Fourth Circuit's law on merger and scènes à faire is comparatively undeveloped. That is to say, research does not reveal an opinion of the court discussing these two doctrines by name; however, the underlying concepts of each doctrine (originality, idea-expression dichotomy) have been analyzed in Fourth Circuit cases, ${ }^{368}$ and to the extent a pattern emerges it is in favor of a circumscribed application of the merger and scènes à faire doctrines with regard to visual works. ${ }^{369}$

Evidence of the rejection of an expansive approach to the merger and scènes à faire doctrines is seen, perhaps ironically, in Superior Form Builders, Inc. v. Dan Chase Taxidermy Supply Co., a case involving

${ }^{365}$ Id. at $208-10$.

366 " As a whole" refers to the total concept and feel test which is accepted and applied in the Third Circuit. See. e.g., Whelan Assocs., Inc. v. Jaslow Dental Lab., Inc., 797 F.2d 1222, 1234 (3d Cir. 1986); Damiano v. Sony Music Entm't, Inc., 975 F. Supp. 623, 631 (D.N.J. 1996).

${ }^{367}$ Kay Berry, 421 F.3d at 208.

${ }^{368}$ E.g., United States ex rel. Berge v. Bd. of Trs. of the Univ. of Ala., 104 F.3d 1453, 1465 (4th Cir. 1997); Superior Form Builders, Inc. v. Dan Chase Taxidermy Supply Co., 74 F.3d 488, 492 (4th Cir. 1996); M. Kramer Mfg. Co. v. Andrews, 783 F.2d 421, 436 (4th Cir. 1986).

${ }^{369}$ E.g., Towler v. Sayles, 76 F.3d 579, 584 (4th Cir. 1996) (using a total concept and feel evaluation in testing the similarity of two motion picture treatments); Dawson v. Hinshaw Music Inc., 905 F.2d 731,733-34 (4th Cir. 1990) (discussing the use of the ordinary observer's evaluation of total concept and feel as part of the intrinsic similarity test). See also Comins v. Discovery Commc'ns, Inc., 200 F. Supp. 2d 512, 521 (D. Md. 2002) (applying a total concept and feel evaluation in comparing two films). 
taxidermy models. ${ }^{370}$ The court evaluated the originality of models formed in part from actual carcasses of animals. ${ }^{371}$ The representation of actual living creatures, particularly in three-dimensional forms with lifelike size and postures, presents a classic situation to interpret the meaning of the idea-expression dichotomy and the breadth of the merger and scènes $\dot{a}$ faire doctrine whether or not these doctrines are discussed by name. The Ninth Circuit, following Satava, would make short work of this issue: There is practically no way that an artist can make a lifelike representation of a living creature and hope to defend it from a plagiarist who copies the work and subsequently produces a lifelike representation of the same creature. ${ }^{372}$

The Fourth Circuit did not take the bait. The court did not dissect the creature into its parts - the result of this process inevitably would be to find an overwhelming number of features that are common to animals in real life as well as to the plagiarist's work. ${ }^{373}$ Therefore, they might be stricken from consideration at any stage of the evaluation, and the court should deny plaintiffs' preliminary injunctions and grant summary judgment or judgment as a matter of law in favor of the defendants, as the court indicated in Satava. ${ }^{374}$ Instead, the Fourth Circuit emphasized that even with lifelike representations, the representation of the animal contains artistic choices and creative input that exceeds the simple idea of the animal itself: "Several sculptors may copy a deer, even the same deer, in creating a sculpture, and each may obtain copyright protection for his or her own expression of the original. Such individual creative efforts inevitably possess some degree of originality." 375 The animal's body is the fact, the idea of the equation; the artist's work is the portrayal, the expression of the idea. ${ }^{376}$ And a portrayal as with other expressions of ideas is protectable under copyright. ${ }^{377}$

\footnotetext{
${ }^{370} 74$ F.3d 488 (4th Cir. 1996).

${ }^{371}$ Id. at $492-95$.

${ }^{372}$ Satava v. Lowry, 323 F.3d 805, 811-13 (9th Cir. 2003).

${ }^{373}$ Id. at $812-13$.

${ }^{374}$ See Superior Form Builders, Inc., 74 F.3d 488, 492 (4th Cir. 1996).

${ }^{375}$ Id. (citing Rachel v. Banana Republic, Inc., 831 F.2d 1503 (9th Cir. 1987)).

${ }^{376}$ See id. at $492,494$.

${ }^{377}$ Id. at $494-495$.
} 


\section{Seventh Circuit}

The Seventh Circuit has avoided the path of applying the doctrines of merger and scènes à faire through a dissection method. ${ }^{378}$ It also has not adopted the abstraction-filtration test. ${ }^{379}$ The court has made a more thoughtful application of the two doctrines than many circuits.

The circuit's rejection of the dissection method and its limited application of the merger and scènes $\dot{a}$ faire doctrines started fairly early in, of all things, a computer program case. In Atari, Inc. v. North American Philips Consumer Electronics Corp., the court examined the ideaexpression dichotomy in the context of video games to determine which elements of the Pac-Man video game were expression, subject to protection, rather than ideas which are in the public domain. ${ }^{380}$ The court rejected the dissection of the subject matter into copyrighted and unprotected elements in favor of examining the "total concept and feel" of the copyrighted work. $^{381}$ The court cautioned that while such dissection was not appropriate, the substantial similarity inquiry "must take into account that the copyright laws preclude appropriation of only those elements of the work that are protected by the copyright." ${ }^{382}$ The reason dissection is inappropriate is that the substantial similarity inquiry is conducted from the perspective of the "ordinary observer, [who] unless he set out to detect the disparities, would be disposed to overlook them, and regard their aesthetic appeal as the same." 383 In other words, an ordinary observer is going to compare the two works in their entirety for both similarities and differences, rather than compare an incomplete, dissected version of the original work to the allegedly infringing work. The Seventh Circuit therefore applies a "total concept and feel" analysis test which "does not

${ }^{378}$ See e.g., Gentieu v. Tony Stone Images/Chicago, Inc. 255 F. Supp. 2d 838, 848 (N.D. Ill. 2003) (citing Atari, Inc. v. N. Am. Philips Consumer Elecs. Corp., 672 F.2d 607, 615 (7th Cir. 1982), superseded by rule in part, Fed. R. Civ. P. 52(a), as recognized in Scandia Down Corp. v. Euroquilt, Inc., 772 F.2d 1423, 1429 (7th Cir. 1985)).

${ }^{379}$ See Nash v CBS, Inc., 899 F.2d 1537, 1540 (7th Cir. 1990) (rejecting the abstractionfiltration test).

${ }^{380} 672$ F.2d 607 (7th Cir. 1982), superseded by rule in part, Fed. R. Civ. P. 52(a), as recognized in Scandia Down Corp. v. Euroquilt, Inc., 772 F.2d 1423, 1429 (7th Cir. 1985) (altering only the standard of review).

${ }^{381}$ Id. at 614 .

${ }^{382}$ Id.

${ }^{383}$ Id. (quoting Peter Pan Fabrics, Inc. v. Martin Weiner Corp., 274 F.2d 487, 489 (2d Cir. 1960)). 
involve 'analytic dissection and expert testimony, ${ }^{384}$ but depends on whether the accused work has captured the 'total concept and feel' of the copyrighted work."385

The total concept and feel test (sometimes phrased as the total look and feel test) does not ignore unprotected elements. The Seventh Circuit admits that, "[i]t is an axiom of copyright law that the protection granted to a copyrightable work extends only to the particular expression of an idea and never to the idea itself." ${ }^{386}$ Thus, "if the only similarity between plaintiff's and defendant's works is that of the abstract idea, there is an absence of substantial similarity and hence no infringement results." 387 The court stated: "When the alleged infringing work is not a duplicate of the copyrighted work, a determination of whether protected elements have been taken requires a close analysis of the differences and similarities between the two works." 388 In other words, a defendant still will be able to defend the charge of infringement by pointing out that the only factors of similarity are unprotectable factors.

The difference in approach is obvious in cases involving creative visual media. The "no dissection-total concept and feel" test was applied to greeting cards in Roulo v. Russ Berrie \& Co., ${ }^{389}$ to three-dimensional stuffed animal heads and tails affixed to duffle bags in Wildlife Express Corp. v. Carol Wright Sales, Inc., ${ }^{390}$ and to a doll's head and facial design in Susan Wakeen Doll Co. v. Ashton-Drake Galleries. ${ }^{391}$ The difference is that the finder of fact (or the court, at the motion stage) is predisposed to evaluating similarities between the original and the allegedly infringing work, not to eliminate elements of the original work before attempting to compare the works. In this manner, obvious similarities between the complete original and the alleged copy will stand out. For example, in Roulo, the court might have looked at the copied elements of the plaintiff's greeting card (striping, font, paper color, font color, size of the card, single-

${ }^{384}$ Id. (citing Arnstein v. Porter, 154 F.2d 464, 468 (2d Cir. 1946)).

${ }^{385}$ Id. (citing Roth Greeting Cards v. United Card Co., 429 F.2d 1106, 1110 (9th Cir. 1970)).

${ }^{386}$ Id. at 615 (quoting Reyher v. Children's Television Workshop, 533 F.2d 87, 90 (2d Cir. 1976)).

${ }^{387}$ Id. (citing 3 M. NIMMER, NIMMER ON COPYRIGHT $§ 13.03(\mathrm{~A})(1)(1981)$ ).

${ }^{388}$ Id. at 614 n.6 (quoting EDMUND W. KITCH \& HARVEY S. PERLMAN, LEGAL REgUlation OF THE COMPETITIVE PROCESS 665 ( $2 \mathrm{~d}$ ed. 1979)).

${ }^{389} 886$ F.2d 931, 939 (7th Cir. 1989).

${ }^{390} 18$ F.3d 502, 510-11 (7th Cir. 1994).

${ }^{391} 272$ F.3d 441, 451 (7th Cir. 2001). 
sided format) as unoriginal stock and trade of the greeting card genre and eliminated them from consideration. Instead, the court noted, "While it is true that these elements are not individually capable of protection, just as individual words do not deserve copyright protection, it is the unique combination of these common elements which form the copyrighted material." 392 Under the total concept and feel evaluation, the court found:

[Defendant Berrie's] TY cards not only used the same unprotectable elements as [plaintiff's] FS cards, but also used them in a format nearly identical to that used by the FS cards. It cannot be disputed that Berrie could have produced a non-infringing card with colored stripes, but Berrie used similar stripes flanking the verse on both the left and right side from top to bottom just as the FS cards did. The color of paper is unprotected, yet the TY cards are printed on a nearly identical beige paper. The use of cursive writing is also a common element as well as the brown ink used, yet TY cards, out of the entire range of colors and handwritings available, chose brown ink and a similar cursive writing. The minute differences which Berrie painstakingly incorporated to prevent a mirror image copy of FS cards are insignificant in light of the nearly identical composition and appearance used in both card lines. ${ }^{393}$

The same is true for the animal heads and tails in Wildlife Export, ${ }^{394}$ the doll head and facial design in Susan Wakeen, ${ }^{395}$ the flatulence-producing

\footnotetext{
${ }^{392}$ Roulo, 886 F.2d at 939.

${ }^{393} \mathrm{Id}$. at 940 .

${ }^{394} 18$ F.3d at $510-11$. The court stated that:
}

Upon consideration of the overall look and character of the duffle bags, or their 'total concept and feel,' ... we see a remarkable resemblance between Wildlife's and Carol Wright's works. They are very similar in size, shape, pose, and feel. We note some dissimilarities in the color and type of plush fur, the animals' eyes and noses; the trunk and the ears of the elephants also differ slightly. However, such variations are, no doubt to some extent, factors of the products available to each company and perhaps of slight adaptations in the patterns. These differences are of minor importance in the overall artistic expression of the entire animal faces and tails under review, and, consequently, they do not preclude a finding of infringement under the ordinary observer test.

Id.

${ }^{395} 272$ F.3d at $451-52$. 
"pull my finger" toy in JCW Investments, Inc. v. Novelty, Inc., ${ }^{396}$ and the picture frames in Stanislawski v. Jordan. ${ }^{397}$

The "no dissection-total concept and feel" test limits the power of the merger doctrine and scènes à faire doctrine in other copyright originality situations. $^{398}$ Even in Bucklew v. Hawkins, Ash, Baptie \& Co., a case presenting a pure Baker $v$. Selden situation involving a computer program, the Seventh Circuit panel did not set out on a path to eliminate elements; instead, the court applied the merger and scènes à faire doctrines in a more circumscribed way. ${ }^{399}$ The alleged plagiarist in Bucklew claimed that a program designed to collect and report HUD data in a tabular format was uncopyrightable under either the merger or the scènes à faire doctrines. ${ }^{400}$ The court recognized the functional nature of the computer program, but pointed out that:

If Bucklew [the original author] were claiming copyright in the tabular presentation of the summary data required by HUD, this case would be governed by Baker $v$. Selden. But he is not. He is claiming copyright in tables configured in an optional way, tables that are the product of format choices that are not unavoidable, for which indeed there were an immense number of alternative combinations any one of which $\mathrm{HAB}$ [the plagiarist] was free to use in lieu of Bucklew's. ${ }^{401}$

With regard to the scènes à faire doctrine, the court further explained:

Every expressive work can be decomposed into elements not themselves copyrightable--the cars in a car chase, the kiss in a love scene, the dive bombers in a movie about Pearl Harbor, or for that matter the letters of the alphabet in any written work. The presence of such elements obviously does not forfeit copyright protection of the work as a whole, but infringement cannot be found on the basis of such elements alone; it is the combination of elements, or

\footnotetext{
${ }^{396} 289$ F. Supp. 2d 1023, 1039 (N.D. Ill. 2003).

${ }^{397} 337$ F. Supp. 2d 1103, 1115 (E.D. Wis. 2004).

${ }^{398}$ See, e.g., Bucklew v. Hawkins, Ash, Baptie \& Co., 329 F.3d 923, 929-30 (7th Cir. 2003).

${ }^{399} \mathrm{Id}$. at 929.

${ }^{400}$ Id. at 928.

${ }^{401}$ Id. at 928 .
} 
particular novel twists given to them, that supply the minimal originality required for copyright protection. ${ }^{402}$

Ultimately, the court preserved the work from the attack of the merger and scènes à faire doctrines, stating:

[Merged and scènes à faire elements] are at the opposite extreme from the arbitrary details, such as the pattern of boldfacing in Bucklew's form 52566, that contribute such originality as a new expressive work may have. The format choices that Bucklew made were not generic. It is not as if everyone who writes programs of this sort uses Swiss font or displays an output range or uses a particular pattern of boldfacing. ${ }^{403}$

The pattern of boldfacing, choice of font, and inclusion of a superfluous output range found in both works were held instead to be evidence of direct copying of Bucklew's work by HAB. ${ }^{404}$

In Gaiman v. McFarlane, the court again evaluated the merger and scènes à faire doctrines, this time in the unusual posture of cartoon artist Todd McFarlane's claim that his own works were not original enough to be copyrighted in order to escape the charge of plaintiff-appellant Neil Gaiman that he was the co-author of a copyrightable work by McFarlane. ${ }^{405}$ In the analysis, the court indicated that under the merger and scènes à faire doctrines, there is a "difference between literary and graphic expression." A medieval knight might be a stock character and the typical verbal description of a medieval knight in armor carrying a shield may be a public domain concept, but the rendering of such a knight in a graphic medium certainly produces a copyrightable work. ${ }^{407}$ There is no standard public domain image of a knight that must be copied by original creator and plagiarist alike in order to communicate the graphic expression of the concept of a medieval knight. ${ }^{408}$

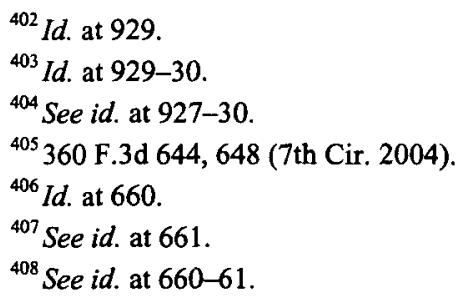


Nevertheless, vigilant repetition of the creed of "no dissection" is necessary to avoid backsliding because the temptation always is present. A recent opinion of the Seventh Circuit indicates the length of time that passed since Atari v. North American Philips, and in the analysis of video games the court no longer seems enamored of the "total concept and feel" of the genre. ${ }^{409}$ In Incredible Technologies, the Seventh Circuit panel appeared eager to cancel out merger and scènes à faire elements from a computer golf simulation program. ${ }^{410}$ Ignoring the plain and abundant evidence of actual copying in the case wherein the plagiarist admitted that its goal was to create a golf simulation game so similar to the plaintiff's game that it could be played without any substantial learning curve, the court instead set off on a course to see how much of the original game it could eliminate from the protection of copyright by application of the merger and scènes à faire doctrines. ${ }^{411}$ With regard to design elements, even visual elements, the court was unimpressed with Incredible Technologies' (IT) visualization of a game of golf recreated through digitalized visual media. ${ }^{412}$ "Even if there are multiple methods by which an operation can be performed, a plaintiff's choice of a particular method of operation is not eligible for protection." plagiarist's suggestions that:

$[\mathrm{M}]$ any elements of the video display were common to the game of golf. For instance, the wind meter and club selection features were found to account for variables in real golf and so were indispensable to an accurate video representation of the game. Furthermore, the court said that the game selection features, such as the menu screens which indicate the number of players and other variables of the game, are common to the video-game format. ${ }^{414}$

The court failed to recognize that while elements of golf such as club selection may be part of any golf game, the particular embodiment of that concept can be protected from direct copying. ${ }^{415}$ It was simpler for the

\footnotetext{
${ }^{409}$ See generally Incredible Techs., Inc. v. Virtual Techs., Inc., 400 F.3d 1007 (7th Cir. 2005).

${ }^{410}$ Id. at $1010-1012,1014-1015$.

${ }^{411}$ Id.

${ }^{412}$ Id. at 1012.

${ }^{413}$ Id. at 1012 (citing Lotus Dev. Corp. v. Borland Int'l, Inc., 49 F.3d 807 (1st Cir. 1995)).

${ }^{414} \mathrm{Id}$. at 1014 .

${ }^{415}$ Id. at 1015 (discussing the lack of protection for video game presentation of standard
} 
court to avoid aesthetic comparisons of the two games and avoid having to instruct the jury on making aesthetic comparisons of the games under the guise of an application of the merger and scènes à faire doctrines. ${ }^{416}$

\section{Eighth Circuit}

The United States Court of Appeals for the Eighth Circuit has a firm grip on the merger and scènes à faire doctrines. ${ }^{417}$ Dissection is not allowed to prevent the ordinary observer from evaluating the total concept and look and feel of the complete works of the original creator and of the alleged plagiarist. ${ }^{418}$

Perhaps the simplest way to characterize the Eighth Circuit test is to consider that the court does not eliminate the possibility of merger and scènes à faire elements just as the court does not reject the originality requirement and the idea-expression dichotomy codified in 17 U.S.C. $\S$ 102(b) and discussed in Feist. ${ }^{419}$ Rather, the court treats the two step extrinsic similarity and intrinsic similarity test as being a two-part test with two independent steps, not a test in which one step (intrinsic) is dependent on a favorable finding on the other step (extrinsic). ${ }^{420}$ They are steps of a test, not elements of a claim or defense. An allegation of merged elements or the presence of scènes à faire elements in the first test will not prevent the court from allowing the finder of fact to consider the second test unless a reasonable ordinary observer could find no similarity in the total concept and look and feel of the two works in the intrinsic analysis, and the only alleged similarity is in common stock elements or a common idea or theme behind the works in the extrinsic analysis. ${ }^{421}$

elements of golf).

${ }^{416} I d$. at 1011 (questioning the usefulness of the "ordinary observer" test as a lay person might not appreciate the idea-expression dichotomy).

${ }^{417}$ See Taylor Corp. v. Four Seasons Greetings, LLC, 315 F.3d 1039, 1043 (8th Cir. 2003); Hartman v. Hallmark Cards, Inc., 833 F.2d 117, 120-21 (8th Cir. 1987); Hoch v. Mastercard Int'l Inc., 284 F. Supp. 2d 1217, 1223 (D. Minn. 2003).

${ }^{418}$ E.g., Hartman, 833 F.2d at 120 (analytical dissection is not called for under the second step in which the response of the ordinary, reasonable person measures the expression).

${ }^{419}$ Feist Publ'ns, Inc. v. Rural Tel. Serv. Co., 499 U.S. 340, 350 (1991). See also Taylor, 315 F.3d at 1042-43 (discussing idea-expression dichotomy and applicability of the merger and scènes à faire doctrines); Hartman, 833 F.2d at 120-21; Hoch, 284 F. Supp. at 1222-23.

${ }^{420}$ See, e.g., Hartman, 833 F.2d at 120.

${ }^{421}$ E.g., Hoch, 284 F. Supp. at 1222-23 (noting that summary judgment was appropriate because no ordinary observer would think total concept and feel of documentary to save 
The doctrines of merger and scènes à faire are circumscribed in the Eighth Circuit, particularly in the case of visual works. Courts in the Eighth Circuit have found the doctrines inapplicable to greeting cards ${ }^{422}$ and quilt designs, ${ }^{423}$ because of the multiple (if not infinite) number of ways that component parts or common ideas can be expressed visually. ${ }^{424}$ But if the intrinsic similarity is lacking, a copyright owner cannot fall back on common public domain elements of the work (similar ideas, similar themes) and make a list of similar features if those features would qualify as merged or scènes à faire elements. ${ }^{425}$ Thus, the balance between the realm of ideas and realm of expressions is preserved.

\section{District of Columbia Circuit}

Sturdza v. United Arab Emirates reveals the District of Columbia Circuit's approach to the merger and scènes à faire doctrines in cases involving visual works. ${ }^{426}$ Sturdza was an architect that brought suit against another architect, Demetriou, for copyright infringement on Sturdza's design for the United Arab Emirates' new embassy. ${ }^{427}$ In the case, the United Arab Emirates (UAE) held a competition for the architectural design of a new embassy and chancery building that it planned to construct in Washington, D.C. ${ }^{428}$ The UAE provided a Program Manual that detailed the requirements for various aspects of the design. ${ }^{429}$ Sturdza and Demetriou both submitted designs, and a board of architects and civil engineers chose Sturdza's design; the UAE notified Sturdza of her win. ${ }^{430}$ The UAE began negotiations with Sturdza, but stopped communicating

Minnesota Twins was similar to Mastercard campaign regarding string of ballpark visits on the intrinsic analysis, and any similarities were attributable only to common idea behind the works of a roadtrip to visit baseball stadiums and scènes à faire elements associated with expression of idea of ballpark visits in the extrinsic analysis).

${ }^{422}$ Taylor, 315 F.3d at 1042-43.

${ }^{423}$ Thimbleberries, Inc. v. C \& F Enters., Inc., 142 F. Supp. 2d 1132, 1138 (D. Minn. 2001).

${ }^{424}$ Taylor, 315 F.3d at 1043; Thimbleberries, 142 F. Supp. 2d at 1138.

${ }^{425}$ Hartman, 833 F.2d at 121 (determining that the only similar features were noncopyrightable ideas or scènes à faire); Hoch, $284 \mathrm{~F}$. Supp. 2d at 1223.

${ }^{426} 281$ F.3d 1287, 1295-97 (D.C. Cir. 2002).

${ }^{427}$ Id. at 1291 .

${ }^{428} \mathrm{Id}$.

${ }^{429}$ Id. at $1291-92$.

${ }^{430}$ Id. at 1292. 
with her without signing a contract proposal. ${ }^{431}$ A year later, Sturdza learned that the UAE had presented an embassy design to the National Capital Planning Commission. ${ }^{432}$ The design belonged to Demetriou, and he had allegedly "copied and appropriated many of the design features that had been the hallmark of her [Sturdza's] design." $" 433$ The court stated that "[ $t]$ he substantial similarity determination requires comparison not only of the two works' individual elements in isolation, but also of their 'overall look and feel.",434 In other words, "[t]he touchstone of the analysis is the overall similarities rather than the minute differences between the two works." 435 The court strove to apply a total look and feel analysis because "protectable expression may arise through the ways in which artists combine even unprotectable elements."

In applying the total look and feel concept to Sturdza's and Demetriou's designs, the court said: "The size, shape, and placement of Demetriou's wind-towers, parapets, and pointed domes, when viewed from the front, give his building a contour virtually identical to Sturdza's." ${ }^{237}$ Furthermore, the court looked at the similarities between the two buildings and stated:

[B]oth buildings have a pyramid-like clustering of pointed arches around the front entrances, prominent horizontal bands and vertical columns demarcating the windows, slightly protruding midsections, diamond grids, and similar latticework patterning inside the arches. Finally, Demetriou achieves the "Islamic" effect sought by the UAE by expressing and combing his wind-towers, arches, dome, parapet, and decorative patterning in ways quite similar to Sturdza's expression and combination of these elements. ${ }^{438}$

The court concluded that despite differences between Demtriou's and Sturdza's designs, and despite the incorporation of various scènes à faire architectural elements (domes, arches, wind-towers, parapets, and Islamic

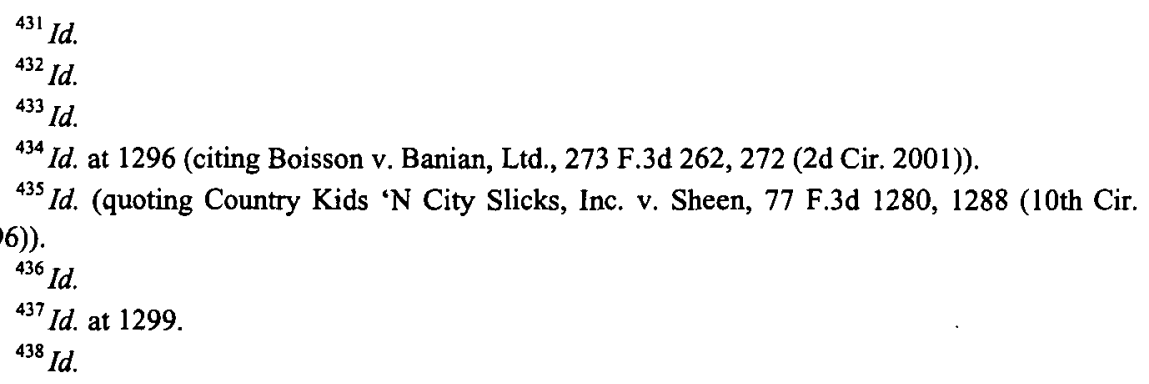


patterns), ${ }^{439}$ Demetriou's design was substantially similar to Sturdza's because the differences were too minute to take away from the total look and feel of Sturdza's design. ${ }^{40}$

The District of Columbia Circuit's restricted view of the merger and scènes à faire doctrines is further revealed in the computer program case of Atari Games Corp. v. Oman. ${ }^{441}$ Instead of following the well traveled path of automatically excluding elements of video games as merged ideas or stock images (paddles, walls, geometric shapes, colors), the court carefully considered the effect of Feist and its holding that combinations of unprotected elements may yet be arranged in an original way and receive copyright protection. ${ }^{442}$ The court noted that the acclaimed artistic works of Mondrian and Malevich were combinations and arrangements of geometric shapes and lines in various colors. ${ }^{443}$ The District of Columbia Circuit reaffirmed its holding in Reader's Digest Association, Inc. v. Conservative Digest, Inc. when it held that layout and typeface elements, although obviously public domain elements, can be combined in a creative and distinctive composite that is copyrightable and protectable from a substantially similar composite put forth by an alleged plagiarist. ${ }^{444}$ In Atari II, the court held that the bricks, rectangular "paddle," side to side motion, and rebounding motion of the ball that were found in plaintiff's BREAKOUT game were part of an original and distinctive whole, even though each part might be common to other video games and thus arguably subject to the merger, scènes $\dot{a}$ faire, or functionality originality defenses. ${ }^{445}$ The court remanded the case twice with instructions for the district court and the Register of Copyrights that the creative combination of unprotected game elements should receive copyright status and subsequent protection from substantially similar infringing games. ${ }^{446}$

${ }^{439}$ Id. at 1297.

${ }^{440} \mathrm{Id}$. at 1299.

${ }^{441}$ See generally 979 F.2d 242 (D.C. Cir. 1992) (Atari II), appeal after remand from 888 F.2d 878 (D.C. Cir. 1989) (Atari I).

${ }^{442}$ Id. at $244-45$.

${ }^{443}$ See id. at 243 n. 1 . The court also posited the rhetorical question: "If Picasso had painted a round object on a canvas, would you say because it depicts a familiar subject - namely, something that's round-it can't be copyrighted?" Id. (citing OddzOn Prods., Inc. v. Oman, 924 F.2d 346, 348 n. 1 (D.C. Cir. 1991)).

${ }^{444}$ Id. (citing Reader's Digest Ass'n, Inc., v. Conservative Digest, Inc., 821 F.2d 800, 806 (D.C. Cir. 1987)).

${ }^{445}$ Id. at $246-47$.

${ }^{446}$ Id. at 247; Atari Games Corp. v. Oman, 888 F.2d 878, 886 (D.C. Cir. 1989). 


\section{REJECTION OF THE MERGER DOCTRINE AND SCÈNES $\dot{A}$ FAIRE DOCTRINE FOR VISUAL WORKS}

Is the substantial similarity test inherently wrong? Are the merger and scènes a faire doctrines simply bad law? The answer to both questions is no. The problem is not the existence of the merger and scènes a faire doctrines. These doctrines are supported by 17 U.S.C. $\S 102(b)$ and the concept of the idea-expression dichotomy discussed and clarified in Feist. $^{447}$ Ideas cannot be copyrighted. ${ }^{448}$ If there is only one way to express an idea, the idea and expression merge and the expression cannot be copyrighted. ${ }^{449}$ Public domain elements of literary works such as standard themes, stock plot devices, standard character types, and clichéd phrases cannot be appropriated by any author. ${ }^{450}$ This is a great blessing in literary works: No one can capture words or phrases or settings or genres by simply being the first to write them down.

The merger and scènes à faire doctrines are a great curse in visual art settings because their application rests on a fallacy: That an idea of a visual work and the expression of the idea can merge, or that artists must copy a standard image in order to depict an idea. ${ }^{451}$ No one captures an idea by being the first to depict it visually. There is never a single way to depict some thing visually -object, creature, or idea. Another depiction is always possible. The presumption behind the application of the merger doctrine to visual works is that if we grant the creator full recognition for her original depiction and original combinations of unprotected elements this will somehow limit the creative potential of the next artist to try her hand at depicting the idea of the scene. ${ }^{452}$ There is no such limitation except that which is within the mind of the second artist who cannot conceive of a different way of depicting the idea and resorts to plagiarism out of frustration for lack of creativity.

The presumption behind the application of the scènes à faire doctrine to visual works is that the original author was forced to choose from a drastically limited number of images to copy in order to properly or

${ }^{447}$ Feist Publ'ns, Inc. v. Rural Tel. Serv. Co., 499 U.S. 340, 350 (1991).

${ }^{448}$ Id.

${ }^{449}$ Kay Berry, Inc. v. Taylor Gifts, Inc., 421 F.3d 199, 209 (3d Cir. 2005).

${ }^{450}$ E.g., Lexmark Int'l, Inc. v. Static Control Components, Inc., 387 F.3d 522, 535 (6th Cir. 2004) (citing Gates Rubber Co. v. Bando Chem. Indus., Inc., 9 F.3d 823, 838 (10th Cir. 1993)).

${ }^{451}$ Satava v. Lowry, 323 F.3d 805, 811-12 (9th Cir. 2003).

${ }^{452}$ See id. at 812. 
efficiently depict the idea, and we cannot blame the plagiarist for also copying one of the images (namely, the original author's). ${ }^{453}$ If that is true, courts should require the defendant to prove which stock image the original author copied to state a prima face case for the application of the scènes $\dot{a}$ faire doctrine as an affirmative defense. Of course, in most cases this will be impossible; most plaintiffs did not copy a prior image, which is what made their original art so attractive for the plagiarist to copy. If the plaintiff did copy another image, her copyright claim would be subject to attack for lack of originality defeating her entire copyright over the work in question. $^{454}$

There are three distinct problems with an expansive application of the merger and scènes à faire doctrines to visual works. First, the merger and scènes à faire doctrines were created to protect the public domain from excessively broad enforcement of literary works whose scope extends to abstractions of the work beyond its actual words so that a plagiarist cannot get away with stealing simply by avoiding the literal ${ }^{455}$ or actual copying of the original author's words. ${ }^{456}$ Infringement of visual works is much more often based on a claim of literal or actual copying; no abstraction of the work is required, and, therefore, there is no need to circumscribe the scope of plaintiff's work to protect the public domain from an expansive protection of abstractions of plaintiff's work. Second, courts applying the merger and scènes à faire doctrines expansively often reveal an inability to understand or appreciate the creative opportunities to express and portray objects visually and to identify and appreciate the contributions of the artist to the work above and beyond the simple ideas behind the works; this

${ }^{453}$ See id.

${ }^{454}$ See Feist Publ'ns, Inc. v. Rural Tel. Serv. Co., 499 U.S. 340, 345 (1991) (stating that originality is required for a copyright).

${ }^{455}$ I hesitate to use the word "literal" (as in "literal copying") with respect to visual works because the term is derived from the same root as "literary" and thus is an apt term to describe word-for-word copying of verbal works and not the copying of visual works. The term "actual copying" used by some courts is not nearly as effective a term because works are "actually" copied by many means other than word-for-word reproduction or photo-mechanical duplication of visual works. My intention is to describe direct copying of the actual content of visual works, but not necessarily limited to photo-mechanical means such as photographing, photocopying, or scanning. Copying the actual content of a visual work by hand still is direct copying of the content of the work; it is not simply copying an abstraction of the work. To communicate this concept I will use the terms "literal" or "actual copying" as these are the terms the courts use, with apologies to my readers for perpetuating any confusion over these terms.

${ }^{456}$ See e.g., Nichols v. Universal Pictures Corp., 45 F.2d 119, 121 (2d Cir. 1930). 
causes the courts to discount creative combinations and additions to works that have connections to preexisting objects and prior works. ${ }^{457}$ Third, far from exercising humility out of their ignorance, courts are unwilling to allow jurors to take on the burden and make an analysis of the total concept and look and feel of the works at issue. ${ }^{458}$ Instead, courts apparently want to avoid aesthetic determinations altogether by creating the opportunity (through the dissection and filtration tests) to eliminate parts of the original work until it is reduced to such a small sum of parts that it appears as a matter of law that there is not a substantial enough amount of overlap between the two works for a finding that defendant inappropriately copied plaintiff's work. $^{459}$ Often this is done in the face of obvious or even admitted copying of the creative, original components of the visual work by the defendant.

\section{A. Allegations of Literal or Actual Copying Defeat the Need for the Application of the Merger and Scènes à Faire Doctrines}

Copying is the primary activity that a copyright prevents. ${ }^{460}$ The subtle flaw in the logic of the application of the merger doctrine and scènes a faire doctrines to visual works is that the concepts of merger and scènes à faire attempt to demonstrate that the defendant need not have copied plaintiff's work in order to produce her own because the idea behind the two works or the nature and genre of the works dictate the embodiment of the idea in a single or a severely limited number of ways. ${ }^{461}$ The theory is that the original creator was limited by these same forces, so who can blame the defendant for being coerced by these forces into creating her work in a way that shares similarities with the plaintiff's work. This is true in literary settings. ${ }^{462}$ It is not true in visual settings.

In literary settings, if you want to express the idea of darkness, you have to use the word "dark" or one of a limited number of synonyms of that

${ }^{457}$ Satava, 323 F.3d at 811.

${ }^{458}$ See e.g., Incredible Techs., Inc. v. Virtual Techs., Inc., 400 F.3d 1007, 1011 (7th Cir. 2005) (questioning the usefulness of an "ordinary observer" test).

${ }^{459} \mathrm{Id}$. at 1010-1012, 1014-1015.

${ }^{460} \mathrm{I}$ intend no insult to the importance of the other rights granted in 17 U.S.C. $\S 106$, but prevention of unauthorized copying is the most important right protected by the copyright laws.

${ }^{461}$ See Satava, 323 F.3d at 811-12 (stating that ideas provided by nature are not subject to copyright and even original contributions were only narrowly protected).

${ }^{462}$ Bucklew v. Hawkins, Ash, Baptie \& Co., 329 F.3d 923, 929 (7th Cir. 2003). 
word. No one can stop the next author from "copying" the word dark in order to express the idea of darkness. The first author was as limited by the available means provided by the English language in expressing the idea of darkness in writing as the second author was. If a dark and rainy night is the concept an author wishes to express, no one can accuse that author of copying the words "dark and rainy night" to express that concept. The words are necessary or at least the most efficient way to express the concept. If standing under a streetlight while the rain pours down your neck on a dark and rainy night is the idea the author wishes to express, he or she is able to use most if not all of these words to express it. This is the meaning of merger: The idea and the expression merge when there is only one way or practically only a very limited number ways of expressing the concept. ${ }^{463}$

The concept of scènes à faire works a similar protection in literary works. A genre cannot be captured by being the first to write in it (mysteries, crime stories, romance novels, coming-of-age stories, buddieson-a-roadtrip stories). ${ }^{464}$ Character types cannot be protected simply by describing the type (a lazy husband, a wise old man, a jealous or desperate housewife). ${ }^{465}$ Settings cannot be monopolized simply by working them into your writing (a sleazy dive, a brightly lit restaurant, Red Square in Moscow, Fifth Avenue in Manhattan between 57th and 59th Streets). ${ }^{466}$ If another person wanted to put a scene on Red Square they would have to use the words "Red Square" and when they describe it they no doubt will use similar words as previous authors have used because they have to use those words, not because they have to copy another author's description of the scene.

Literary works, including for the most part motion pictures, enjoy the freedom preserved by the merger and scènes à faire doctrines because in most disputes the fight is not over overt, word-for-word copying of text or actual taping and reproduction of segments of film or television or video. In no case involving books or screenplays or motion pictures or television cited in this Article was the issue that the defendant actually copied the words of the plaintiff or taped and reproduced a segment of the plaintiff's audiovisual work; these scenarios come up in other copyright disputes over

\footnotetext{
${ }^{463}$ Kay Berry, Inc. v. Taylor Gifts, Inc., 421 F.3d 199, 209 (3d Cir. 2005).

${ }^{464}$ See Nash v. CBS, Inc., 899 F.2d 1537, 1540 (7th Cir. 1990).

${ }^{465}$ See, e.g., Walker v. Time Life Films, Inc., 784 F.2d 44, 50 (2d Cir. 1986) (stating that drunks, prostitutes, and policemen would be in any realistic work about the South Bronx).

${ }^{466}$ Herzog v. Castle Rock Entm't, 193 F.3d 1241, 1248 (11th Cir. 1999).
} 
ownership or fair use. Copyright law expands the protected expression of the author beyond the simple arrangement of words on the page or text on the screenplay to cover creative elements of plot, specific scenes, and specific characters created by the author. ${ }^{467}$ Thus, one cannot duplicate the original plot, original characters, and original storyline of a literary work and escape liability just by changing the wording. The merger doctrine and scènes $\grave{a}$ faire doctrine both work to make sure an author does not monopolize the general themes and settings and stereotypical character types when a second author sets off to plow the same ground.

The scope of the plaintiff's literary work extends beyond the words to a reasonable and limited number of abstractions of the work encompassing the original plot, original characters, and original storyline of the work. ${ }^{468}$ As described by Judge Learned Hand in Nichols, there is no way to predict exactly how many levels of abstraction can or should be protected regarding an individual work. ${ }^{469}$ Some works may be so creative and original that many levels of abstraction will still contain protected original expression that should not be freely copied by a later plagiarist.

None of this has any relevance to visual works. There are no stock images existing in some Platonic realm of ideas that must be copied in order to communicate the ideas. Abstraction is not necessary because it is literal or actual copying that is the subject of plaintiff's complaint. It is true that at a certain level of abstraction, some images will share common features with other images. If a person sets out to portray a flag, most will arrive with a pole and a rectangular piece of fabric that is curved slightly to reveal its flexible, flag-like nature. If a person sets out to portray an American flag, the same rectangular piece of fabric on the pole will have red, white, and blue coloring on it. That is it; there is no singular image necessary to copy to communicate flag, unlike in a literary sense in which a limited number of words (i.e., flag, American, United States, U.S.A.) necessarily must be used to communicate the same concept.

The vast majority of copyright actions about visual media concern literal or actual copying. As an artist, I can tell you from experience that it is monumentally unusual for an artist depicting the same subject as another artist to come up with a substantially similar work as the other artist unless she copies the work of the other. Monet and Renoir stood side by side

\footnotetext{
${ }^{467}$ Nichols v. Universal Pictures Corp., 45 F.2d 119, 121 (2d Cir. 1930).

${ }^{468}$ Id.

${ }^{469} I d$.
} 
painting bathers at La Grenouillere (the "Frog Pond") and practicing the principles of Impressionism, the school of art that they founded, yet each produced a singular, original work indicative only in the one case of Monet's hands ${ }^{470}$ and in the other of Renoir's hands. ${ }^{471}$ However, if one copied the other's work, the similarity might have been staggering.

\section{B. Judges Reveal an Ignorance of Creative, Original Artistic Combinations and Additions to Works Through an Expansive Application of the Merger and Scènes à Faire Doctrines}

There is a simple explanation for the many unusual outcomes of visual art cases in the First, Fifth, Sixth, Ninth, Tenth, and Eleventh Circuits: Courts fail to understand or appreciate the creative opportunities to express and portray objects visually and to identify and appreciate the contributions of the artist to the work above and beyond the simple ideas behind the works. This causes the courts to discount creative combinations and additions to works that portray objects and scenes from the real world or contain original combinations of unoriginal elements. ${ }^{472}$ Justice Oliver Wendell Holmes predicted this problem when he stated:

It would be a dangerous undertaking for persons trained only to the law to constitute themselves final judges of the worth of pictorial illustrations, outside of the narrowest and most obvious limits. At the one extreme some works of genius would be sure to miss appreciation. Their very novelty would make them repulsive until the public had learned the new language in which their author spoke. It may be more than doubted, for instance, whether the etchings of Goya or the paintings of Manet would have been sure of protection when seen for the first time .... That these pictures had their worth and their success is

${ }^{470}$ See http://p.giroud.free.fr/monet/grenouillere.jpg (last visited Oct. 14, 2006).

${ }^{471} \mathrm{See}$ http://www.lannaronca.it/Renoir/La\%20Grenouillere.jpg (last visited Oct. 14, 2006).

${ }^{472}$ See, e.g., Satava v. Lowry, 323 F.3d 805, 810-13 (9th Cir. 2003) (discussing the difficulty in obtaining a copyright for work based on natural objects and the "thinness" of the protection even if obtained). 
sufficiently shown by the desire to reproduce them without regard to the plaintiffs' rights. ${ }^{473}$

Justice Holmes was addressing many courts' failure to appreciate the originality and creativity of certain visual works in the initial copyrightability analysis. The same failure occurs when the courts do not recognize the creative combinations and additions to visual works that allow the works to surpass the common, public domain ideas of the subject matter of the works. At the one extreme is the Ninth Circuit's declaration that it is virtually impossible to render a lifelike artistic depiction of a living creature with enough originality to preclude a plagiarist from making a patently similar copy of the first work. ${ }^{474}$ The holding of the Ninth Circuit in Satava cannot be reconciled with the holding of the Third Circuit in Franklin Mint ${ }^{475}$ and Masquerade Novelty, ${ }^{476}$ the Fourth Circuit in Superior Form Builders, ${ }^{477}$ the Seventh Circuit in Wildlife Express Corp. v. Carol Wright Sales, Inc., ${ }^{478}$ and the Ninth Circuit itself in Kamar International. ${ }^{479}$ At another extreme is Yankee Candle, in which the First Circuit held that creative combinations of common, unoriginal photographic elements cannot add up to a protectable, original whole. ${ }^{480}$ These cases are in direct contradiction of the holding of Feist, ${ }^{481}$ as well as the holdings of dozens of other circuit court cases that have protected the rights of authors of works containing creative, original, and protectable combinations of unoriginal components. ${ }^{482}$ If anything, this split in the circuits should counsel judges to avoid a rash determination that there are no protectable creative elements

${ }^{473}$ Bleistein v. Donaldson Lithographing Co., 188 U.S. 239, 251-52 (1903) (citing Henderson v. Tompkins, 60 F. 758, 765 (C.C. Mass. 1894)).

${ }^{474}$ Satava, 323 F.3d at 810-13.

${ }^{475}$ Franklin Mint Corp. v. Nat'l Wildlife Art Exch., Inc., 575 F.2d 62, 66-67 (3d Cir. 1978).

${ }^{476}$ Masquerade Novelty, Inc. v. Unique Indus., Inc., 912 F.2d 663, 671-72 (3d Cir. 1990).

${ }^{477}$ Superior Form Builders, Inc. v. Dan Chase Taxidermy Supply Co., 74 F.3d 488, 492 (4th Cir. 1996).

${ }^{478}$ See generally 18 F.3d 502 (7th Cir. 1994).

${ }^{479}$ See generally Kamar Int'1, Inc. v. Russ Berrie \& Co., 657 F.2d 1059 (9th Cir. 1981).

${ }^{480}$ See generally Yankee Candle Co. v. Bridgewater Candle Co., 259 F.3d. 25 (1st Cir. 2001).

${ }^{481}$ Feist Publ'ns, Inc. v. Rural Tel. Serv. Co., 499 U.S. 340, 348 (1991).

${ }^{482}$ E.g., Bucklew v. Hawkins, Ash, Baptie \& Co., 329 F.3d 923, 929 (7th Cir. 2003); Tufenkian Imp./Exp. Ventures, Inc. v. Einstein Moomjy, Inc., 338 F.3d 127, 135-136 (2d Cir. 2003); Boisson v. Banian, Ltd., 273 F.3d 262, 273 (2d Cir. 2001); Atari Games Corp. v. Oman, 979 F.2d 242, 245 (D.C. Cir. 1992); Roulo v. Russ Berrie \& Co., 886 F.2d 931, 939 (7th Cir. 1989); Reader's Digest Ass'n, Inc. v. Conservative Digest, Inc., 821 F.2d 800, 806 (D.C. Cir. 1987). 
in works that depict natural objects or contain creative combinations of common, unoriginal elements or subject matter. Feist held that the standard for creativity and originality is intentionally low and the vast majority of works should make the grade quite easily. ${ }^{483}$ Yet, half of the circuits of the United States courts of appeals have seen fit to dissect and filter out the elements of creative visual works through an expansive application of the merger and scènes à faire doctrines, reducing the works to a pile of random elements that no rational finder of fact can compare to an alleged plagiarist's work in a determination of substantial similarity.

\section{An Expansive Application of the Merger and Scènes à Faire} Doctrines Denies Visual Artists the Protection of the Copyright Laws by Taking the Substantial Similarity Determination Away From the Finder of Fact

The subtext of this discussion of the expansion in the application of the merger and scènes à faire doctrines to visual works is that many if not most of the cases applying the doctrines through a dissection and filtration analysis wind up determining that the case can be taken away from the jury on summary disposition because so much of the plaintiff's work has been dissected and filtered away that there is nothing substantial left for the alleged plagiarist to have copied. This practice denies visual artists the right to have the intrinsic similarity of their works and the alleged plagiarist's works evaluated by the finder of fact.

The Ninth Circuit shows the development of this process in Aliotti v. $R$. Dakin \& Co., a case involving depictions of actual creatures (albeit dinosaurs). ${ }^{484}$ The court reconsidered the intrinsic similarity test so as to better accommodate the merger doctrine. ${ }^{485}$ First, the court noted:

[T] he district court's determination as to substantial similarity of expression relied incorrectly on the analytic dissection of the dissimilar characteristics of the dolls. Similarity of expression exists only when 'the total concept and feel of the works' is substantially similar. Dissection of dissimilarities is inappropriate because it distracts a

\footnotetext{
${ }^{483}$ Feist, 499 U.S. at 345.

${ }^{484} 831$ F.2d 898 (9th Cir. 1987).

${ }^{485}$ Id. at 901 .
} 
reasonable observer from a comparison of the total concept and feel of the works. ${ }^{486}$

The subtle insertion of the word "dissimilarities" was important because the court was about to make a point about dissection of similarities in an effort to open the door to the merger doctrine in visual media cases:

To the extent that it is necessary to determine whether similarities result from unprotectable expression, it is appropriate under Krofft's intrinsic test to perform analytic dissection of similarities. Although even unprotectable material should be considered when determining if there is substantial similarity of expression, no substantial similarity may be found under the intrinsic test where analytic dissection demonstrates that all similarities in expression arise from the use of common ideas. ${ }^{487}$

Thus, dissection entered the intrinsic portion of the similarity test, albeit after the "total concept and feel" of the works as a whole was evaluated by the finder of fact. ${ }^{488}$ If there was no substantial, intrinsic similarity as to the works as a whole, the case was closed; however, if there was substantial, intrinsic similarity as to the works as a whole, the similar features of the works could then be dissected and separately analyzed to make sure that all similarities were not as to unprotected elements.

Aliotti recognized that courts that are intent on expanding the application of the doctrine would find it hard to accomplish this in the face of the total concept and feel standard. ${ }^{489}$ Total concept and feel is a standard for ordinary observers, namely the jury as finder of fact in many copyright actions. In light of this fact, courts typically pay lip service to the proposition that the intrinsic similarity determination using the total concept and feel standard is not proper for summary disposition. ${ }^{490}$ The total concept and feel standard finds its support in the bedrock copyright law stating that original combinations of uncopyrightable components can be

\footnotetext{
${ }^{486} / d$. (emphasis added) (citations omitted).

${ }^{487}$ Id. (emphasis in original) (citations omitted).

${ }^{488}$ See id.

${ }^{489}$ Id. at $900-903$.

${ }^{490} \mathrm{See} i \mathrm{~d}$. at 900 (stating that summary judgment is not favored in substantial similarity
} cases). 
protected ${ }^{491}$ therefore, the evaluator must look at the total combination, not a stripped down combination when comparing it to the alleged plagiarist's work. By shelving the total concept and feel test, and stressing the dissection and filtration of allegedly merged and scènes à faire material, the court creates the opportunity for summary disposition of the suit-the more material that is stripped away from plaintiff's work, the more comfortable the court will be with finding as a matter of law that no average person could find the two works to be substantially similar as to the few items remaining in the plaintiff's work. If a court takes the total concept and feel standard seriously it almost guarantees a jury trial unless the two works in their entirety are simply and manifestly dissimilar. Taking away a stripped down plaintiff's creation from the jury is an easier call than making an aesthetic determination that an average person could not find substantial similarity in the two works as a whole. An expansive application of the merger and scènes à faire doctrines makes this possible by providing a rationale, albeit a misguided rationale, for dissecting and filtering out components of plaintiff's work.

\section{CONCLUSION: RECOMMENDATIONS AND SOLUTION?}

The current state of the law in at least half of the circuits of the United States courts of appeals is to apply the merger and scènes à faire doctrines to visual works in a frequent and far reaching manner. The principle result is that the authors of creative visual compilations and depictions and portrayals of objects and entities found in the real world are denied the full protection of copyright promised by the originality standard of Feist. ${ }^{492}$ A secondary result is that many copyright cases in which the plaintiff lacks actual proof of direct copying are resolved by summary disposition as opposed to jury trials even though the two step substantial similarity test is supposed to contain an ordinary observer standard that is not appropriate for summary disposition. After an expansive application of the merger or scènes à faire doctrine to a plaintiff's visual work, there often is little or nothing to compare side-by-side with the alleged plagiarist's work which necessitates summary judgment for the plagiarist. I offer the following solution to the problem followed by alternative recommendations if the solution offered is not acceptable.

\footnotetext{
${ }^{491}$ Feist Publ'ns, Inc. v. Rural Tel. Serv. Co., 499 U.S. 340, 348 (1991).

${ }^{492}$ Id.
} 


\section{A. Solution: Eliminate the Application of the Merger and Scènes à Faire Doctrines to Visual Works}

The most satisfactory solution is for courts to advance the law by finding that the merger and scènes à faire doctrines do not apply to visual works. The merger doctrine should not apply in situations were an idea can be depicted in innumerable ways either through original creation or by original combinations of otherwise unprotected elements. Visual works are a classic example of a situation where ideas can be depicted visually in innumerable ways which should preclude application of the merger doctrine. Furthermore, authors of visual works on the whole do not copy a stock image in the way that literary works adopt and express a stock scene or situation. There is no set of images that must be copied in order to depict the idea of the image. In the absence of proof that plaintiff did in fact copy a preexisting stock image or "required" image, the merger and scènes $\grave{a}$ faire doctrines should not apply to visual media.

\section{B. Recommendation: Impose a Burden on the Alleged Plagiarist to Produce the Image Copied by the Original Artist in Order to \\ Trigger the Application of the Merger and Scènes à Faire Doctrines to Visual Works}

Short of overturning decades of law, the courts could interpret the merger and scènes à faire doctrines more logically and require the alleged plagiarist to produce the image (the stock scènes a faire image or the single, acceptable expression of the merged idea) that plaintiff must have copied to prove that one or both of the two doctrines apply. Successfully raising this affirmative defense would in effect prove that plaintiff's work was not original and, thus, not deserving of copyright protection; that is the correct interpretation of situations in which the merger and scènes à faire doctrine should apply. The current interpretation of the two part substantial similarity test puts the burden on the plaintiff to establish both extrinsic similarity and intrinsic similarity. Courts step in to interfere with this process by asserting that the plaintiff's creation contains merged and scènes à faire elements, doubling the burden of the plaintiff. To get to a jury, the plaintiff must not only show factual, objective similarity but also stave off the court's efforts to reduce her work to a dissembled pile of elements by dissecting and filtering out alleged merged and scènes à faire elements. If the court's application of the merger and scènes à faire doctrine is broad enough, the court will not be receptive to the argument that original and 
creative compilations of even unprotectable elements may enjoy copyright protection and the court will prevent the work from being evaluated as a whole by the finder of fact.

\section{Recommendation: Allow the Finder of Fact to Evaluate the Total Look and Feel of the Two Competing Visual Works, but Impose a Check on the Process with Sspecial Verdict Forms}

If the major premises of my argument are not accepted, and courts insist that the merger and scènes à faire doctrines apply to visual works, I have one last suggestion: Allow the jury to evaluate the works as a whole, but require the jury to identify through jury interrogatories or a special verdict form the elements of the two works that are similar. Then, the court would have an opportunity to intervene in a situation where the only items of similarity identified by the jury are merged, scènes à faire, or other public domain features common to the two works and many others. In this way, the jury is allowed to evaluate the two works as a whole, but the court has built in a check and balance that can halt the jury's progress into enforcement of a copyright through protection of unprotectable subject matter. This method is contemplated by both the Ninth Circuit in Aliotti in its recommendation that the court examine the findings of a "total concept and feel" analysis to make sure the items of intrinsic similarity are not all unprotected items, ${ }^{493}$ and by the Second Circuit in Boisson when the court's model for a "more discerning observer" test would require well drafted jury instructions to teach the jury to make a discerning comparison of the competing works that is not based on similarities of unprotectable elements of plaintiff's work. ${ }^{494}$

The merger and scènes à faire doctrines have their place in copyright law; their place is with literary works that depend on abstraction for a full protection of the works' creative expression of the general ideas behind the works. Visual works do not rely on levels of abstraction or on abstraction at all. The vast majority of claims of infringement of visual works concern literal or actual copying, not the borrowing of the abstract expressions of the work.

In most cases, defendants will not be able to point to a preexisting image (a stock scènes à faire image, or the single image that merges with the idea of the image) that was copied by the plaintiffs and that

\footnotetext{
${ }^{493} 831$ F.2d at 901 .

${ }^{494}$ See Boisson v. Banian, Ltd. 273 F.3d 262, 272 (2d Cir. 2001).
} 
subsequently defendants did copy or might have copied in the production of their own visual work. If such an image exists it should be raised as an affirmative attack on the originality of the plaintiff's work. This would be the logical justification for the application of the merger and scènes a faire doctrines to visual works. Instead, courts use the doctrines to chip away at creative visual compositions and original combinations of original and unoriginal elements until the work is reduced to a state where no one could find that it was substantially similar to another work. That the merger and scènes à faire doctrines encompass visual images in the public domain that visual artists are required to copy in order to depict or portray certain ideas is a fallacy perpetrated by half of the circuits of the United States courts of appeals. Only by recognizing the common creative practices of visual artists and recognizing the full scope of protection that Feist affords to original works and original combinations of unoriginal elements of visual works can this fallacy be dispelled. 